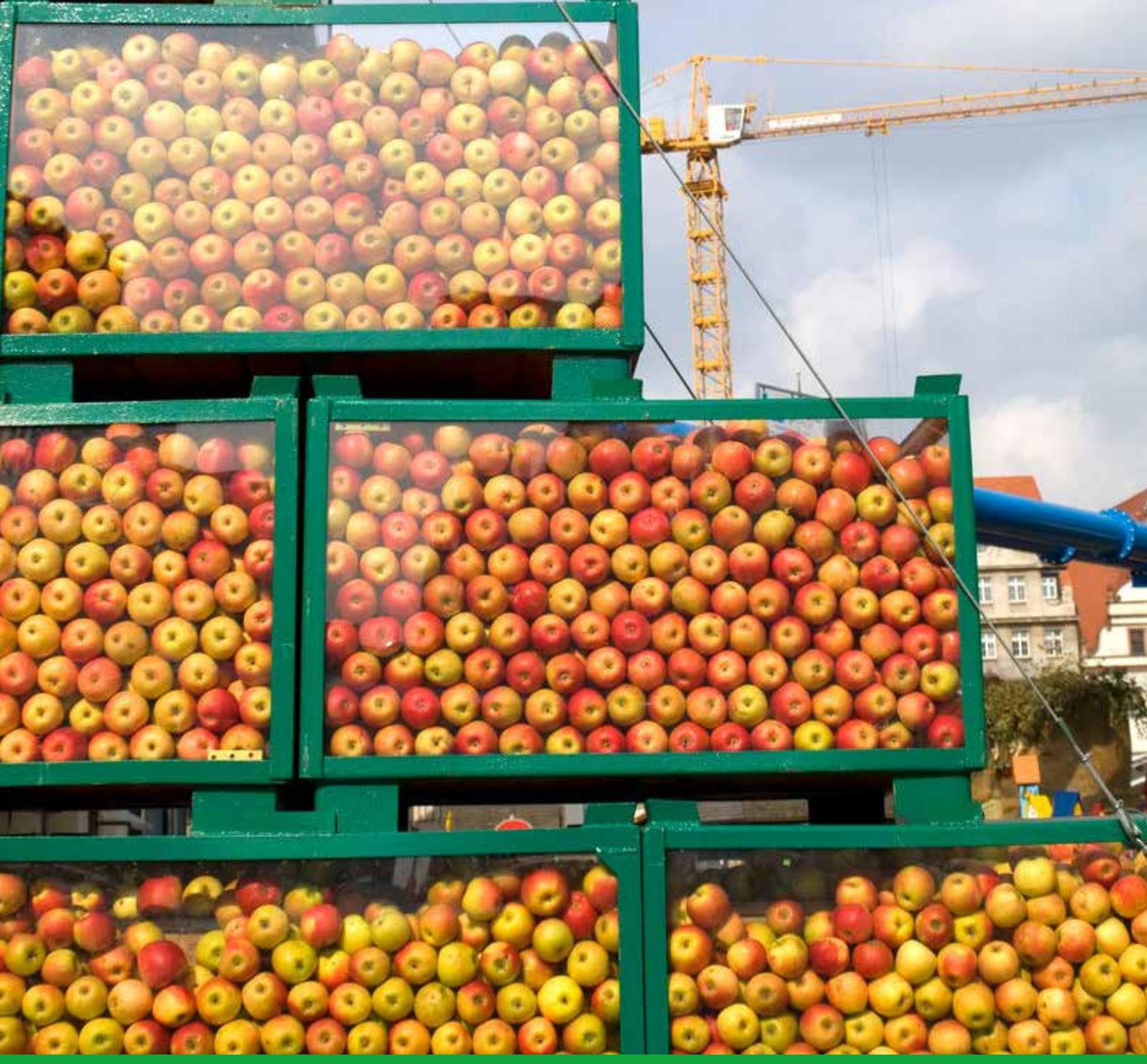

De toekomst van de land- en tuinbouw in Nederland, binnen de Europese en mondiale context

Willem-Jan van Zeist, Andrzej Tabeau en Hans van Meijl

WAGENINGEN

UNIVERSITY \& RESEARCH 



\section{De toekomst van de land- en tuinbouw in Nederland, binnen de Europese en mondiale context}

Willem-Jan van Zeist, Andrzej Tabeau en Hans van Meijl

Dit onderzoek is uitgevoerd door Wageningen Economic Research en gesubsidieerd door het ministerie van Landbouw, Natuur en Voedselkwaliteit, in het kader van het Beleidsondersteunend onderzoeksthema 'Agro-economie en GLB' (projectnummer BO-43-014.01-088)

Wageningen Economic Research

Wageningen, december 2021 
Zeist, W.J. van, A. Tabeau en H. van Meijl, 2021. De toekomst van de land- en tuinbouw in Nederland, binnen de Europese en mondiale context. Wageningen, Wageningen Economic Research, Rapport 2021-135. 76 blz.; 48 fig.; 17 tab.; 11 ref.

Deze verkenning vergaart beelden over de mogelijke toekomstige ontwikkeling van de Nederlandse agrifoodsectoren op de lange termijn (tot en met 2050) en wat die kunnen betekenen voor de handelingsperspectieven voor LNV. Uitgangspunt is een referentiescenario: hoe ontwikkelt de landbouw zich bij ongewijzigd beleid. Vervolgens wordt gekeken naar een aantal varianten daarop. De variatie zit in de mate van vergroening (implementatie Akkoord van Parijs / EU Green Deal) en of die vergroening eenzijdig in de EU of ook wereldwijd plaatsvindt. Een andere variabele is de mate waarin er sprake is van verdere liberalisering (of het tegenovergestelde) van de handel.

This study gathers images about the possible future development of the Dutch agri-food sectors in the long term (until 2050) and what this could mean for the courses of action for LNV. The starting point is a reference scenario: how will agriculture develop if policy remains unchanged. Subsequently, a number of variants are examined. The variation lies in the degree of greening (implementation of the Paris Agreement / EU Green Deal) and whether this greening takes place unilaterally in the EU or also worldwide. Another variable is the degree of further liberalization (or the opposite) of trade.

Trefwoorden: EU Green Deal, Internationale handel, Agri-food, scenario's, economische modellen.

Dit rapport is gratis te downloaden op https://doi.org/10.18174/558083 of op www.wur. nl/economicresearch (onder Wageningen Economic Research publicaties).

(C) 2021 Wageningen Economic Research

Postbus 29703, 2502 LS Den Haag, T 07033583 30, E communications.ssg@wur.nl, www. wur.nl/economic-research. Wageningen Economic Research is onderdeel van Wageningen University \& Research.

\section{(cc) BY-NC}

Dit werk valt onder een Creative Commons Naamsvermelding-Niet Commercieel 4.0 Internationaallicentie.

(C) Wageningen Economic Research, onderdeel van Stichting Wageningen Research, 2021 De gebruiker mag het werk kopiëren, verspreiden en doorgeven en afgeleide werken maken. Materiaal van derden waarvan in het werk gebruik is gemaakt en waarop intellectuele eigendomsrechten berusten, mogen niet zonder voorafgaande toestemming van derden gebruikt worden. De gebruiker dient bij het werk de door de maker of de licentiegever aangegeven naam te vermelden, maar niet zodanig dat de indruk gewekt wordt dat zij daarmee instemmen met het werk van de gebruiker of het gebruik van het werk. De gebruiker mag het werk niet voor commerciële doeleinden gebruiken.

Wageningen Economic Research aanvaardt geen aansprakelijkheid voor eventuele schade voortvloeiend uit het gebruik van de resultaten van dit onderzoek of de toepassing van de adviezen.

Wageningen Economic Research is ISO 9001:2015 gecertificeerd.

Wageningen Economic Research Rapport 2021-135 | Projectcode 2282500418.

Foto omslag: Shutterstock 


\section{Inhoud}

Woord vooraf $\quad 5$

$\begin{array}{ll}\text { Samenvatting } & 6\end{array}$

$\begin{array}{ll}\text { Summary } & 10\end{array}$

$\begin{array}{lrr}1 & \text { Inleiding } & 14\end{array}$

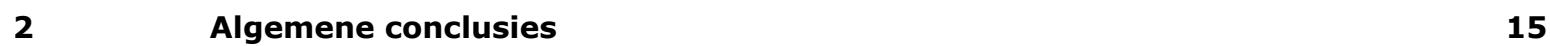

$\begin{array}{llr}3 & \text { Scenario's } & 16\end{array}$

$\begin{array}{lrr}\text { Resultaten } & 19\end{array}$

$5 \quad$ Beperkingen $r 25$

$\begin{array}{ll}\text { Literatuur en websites } & 26\end{array}$

$\begin{array}{lll}\text { Bijlage } 1 & \text { Modeltechnische achtergrond } & 27\end{array}$

$\begin{array}{lll}\text { Bijlage } 2 & \text { Extra tabellen } & 64\end{array}$

$\begin{array}{lll}\text { Bijlage } 3 & \text { Extra decompositiegrafieken } & 68\end{array}$ 



\section{Woord vooraf}

Voor het uitvoeren van verkenningen en ex-ante evaluaties maakt Wageningen Economic Research gebruik van scenario's. In het verleden liet het ministerie van Landbouw, Natuur en Voedselveiligheid (LNV) periodiek onderzoek verrichten naar de toekomst van de landbouw in Nederland via scenariostudies. De laatste studie verscheen in 2011. Deze onderzoeken betroffen modelmatige verkenningen van de toekomst en Wageningen Economic Research gebruikte daarvoor modellen waar zowel de mondiale als de Europese en nationale stand van zaken en ontwikkelingen werden gepresenteerd en met elkaar verbonden. Wageningen Economic Research is nog steeds actief in het wereldwijde consortium dat het mondiale model (GTAP) actief beheert en verder ontwikkelt. De Wageningen Economic Research-variant van dit model met een focus op de agrifood (bio-economie) sectoren is de Modular Applied General Equilibrium Tool (MAGNET).

MAGNET is een economisch evenwichtsmodel waar inmiddels verscheidene niet-economische parameters mee zijn verbonden. Bijvoorbeeld de relatie tussen handel en klimaat, maar ook de implicaties van beide thema's voor de voedselzekerheid. In ieder geval is het mogelijk variabele condities voor de handel te modelleren, zoals bijvoorbeeld meer of minder vrijhandel of voorkeur voor lokale producten. Op die manier zijn ook de effecten van geopolitieke ontwikkelingen (bijvoorbeeld handelsoorlogen en de consequenties daarvan) of stokkende handelsstromen door bijvoorbeeld uitbraken van pandemieën met het model door te rekenen.

LNV heeft Wageningen Economic Research opdracht verleend onderzoek te verrichten naar beelden over de mogelijke toekomstige ontwikkeling van de Nederlandse agrifoodsectoren op de lange termijn (tot en met 2050) en wat dit kan betekenen voor de handelingsperspectieven voor LNV. Het inbedden in een internationale context is hierbij cruciaal. Hiertoe zijn vergroeningsscenario's en varianten van handelsbeleid opgezet en de effecten voor Nederland, EU, en wereldwijd geanalyseerd in scenario's lopend tot 2050. Deze publicatie doet verslag van dit onderzoek. Een woord van dank is verschuldigd aan de leden van de begeleidingscommissie van LNV die dit onderzoek met hun kennis en ervaring hebben ondersteund, te weten:

- dr. H.F. (Henk) Massink, directie Strategie Kennis en Innovatie (SK\&I), voorzitter

- A. (Aldert) van Eck, MSc, directie Dierlijke Agroketens en Dierenwelzijn (DAD)

- drs. A. (Arne) Meeter, directie Europese, Internationale en Agro-economisch Beleid (EIA)

- dr. E.J. (Evert) Visser, directie Plantaardige Agroketens en Voedselkwaliteit (PAV)

- dr. B.S.I. (Bjørn) Volkerink, directie Strategie, Kennis en Innovatie (SK\&I).

Ten slotte bedanken wij iedereen die verder aan de totstandkoming van dit rapport heeft bijgedragen.

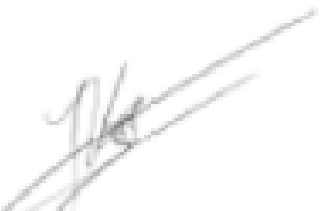

Prof.dr.ir. J.G.A.J. (Jack) van der Vorst Algemeen Directeur Social Sciences Group (SSG) Wageningen University \& Research

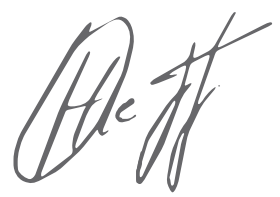

Ir. O. (Olaf) Hietbrink

Business Unit Manager Wageningen Economic Research Wageningen University \& Research 


\section{Samenvatting}

\section{S.1 Kernvraag}

Deze verkenning vergaart beelden over de mogelijke toekomstige ontwikkeling van de Nederlandse agrifoodsectoren op de lange termijn (tot en met 2050) en wat die kunnen betekenen voor de handelingsperspectieven voor LNV. Wat zijn de mogelijke gevolgen van een aantal drijvende krachten voor zover nu bekend - die de toekomst bepalen van de Nederlandse land- en tuinbouw? Uitgangspunt is een referentiescenario: hoe ontwikkelt de landbouw zich bij ongewijzigd beleid. Vervolgens wordt gekeken naar een aantal varianten daarop. De variatie zit in de mate van vergroening (implementatie Akkoord van Parijs/Green Deal) en of die vergroening eenzijdig in de EU of ook wereldwijd plaatsvindt. Een andere variabele is de mate waarin er verdere liberalisering van de handel is.

In de vergroeningsscenario's is de aanname dat de druk op het milieu verminderd door beprijzing van de uitstoot van broeikasgassen, verandering naar een plantaardiger dieet, vermindering van voedselverspilling, en meer grond voor natuur. De beprijzing van broeikasgassen wordt geïmplementeerd via een $\mathrm{CO}_{2}$-equivalententaks $\left(\mathrm{CO}_{2}\right.$-eq-taks) die een benadering is van allerlei kosten die gemaakt moeten worden om emissies te verlagen. De variaties in de mate van verdere handelsliberalisering zijn voor de Nederlandse agrarische sector van groot belang aangezien die erg op export is gericht, maar ook afhankelijk is van import. Onzekerheden zijn hier of de internationale handel wordt bevorderd door verdere verlaging van invoertarieven, of wordt beperkt door varianten van Europees handelsbeleid met importtarieven die een interne $\mathrm{CO}_{2}$-equivalententaks $\left(\mathrm{CO}_{2}\right.$-eq-taks) compenseren of doordat consumentenvoorkeuren verschuiven naar lokale producten. Daarvoor kunnen diverse oorzaken zijn zoals voorkeur voor duurzame producten, de Covid-pandemie die invoer van ver weg kwetsbaar maakt en overige geopolitieke ontwikkelingen die leiden tot verdere regionalisering. Deze twee onzekerheden leiden tot de 4 scenario's (zie figuur S.1). Alle scenario's worden vergeleken met een referentiescenario waarin geen vergroening ten opzichte van het huidige beleid plaatsvindt. Het mondiale algemeen economische evenwichtsmodel MAGNET wordt gebruikt voor de implementatie en kwantificering van de scenario's.

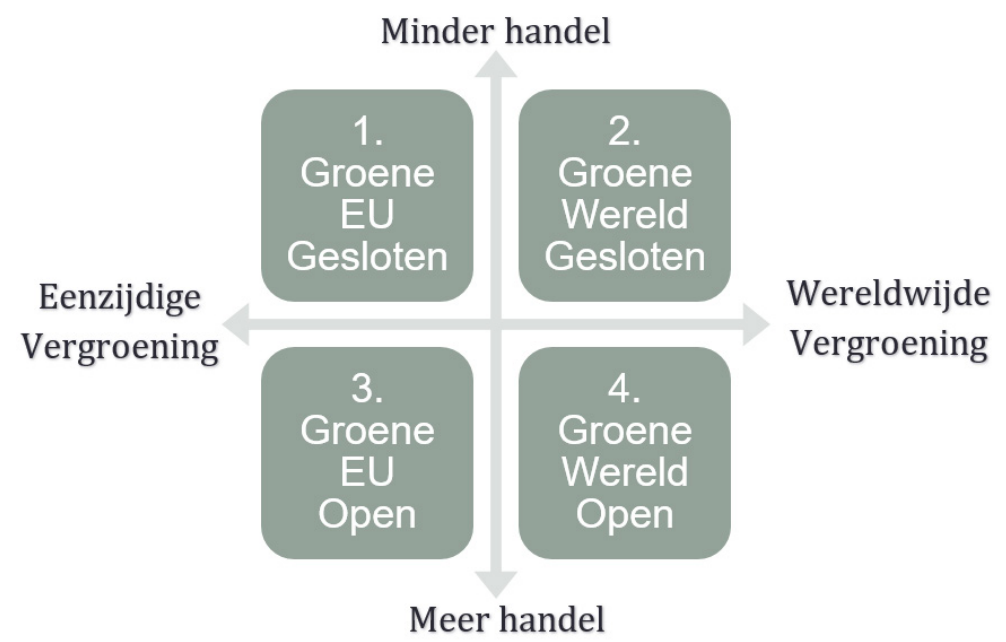

Figuur S.1 Scenariomatrix

Deze studie kijkt met name naar de gevolgen van deze factoren (zowel qua vergroening als qua handelsbeleid) in de verschillende scenario's op productieomvang, broeikasgasemissies, toegevoegde waarde, werkgelegenheid, productieprijzen, en de internationale handelspositie. Deze scenariostudie op de lange termijn (2050) richt zich op de landbouw die voor de Europese en de wereldmarkt produceert. 
Er wordt van uitgegaan dat de stikstofproblematiek op de middellange termijn wordt aangepakt conform de ruimtelijke zonering op basis van het principe 'de juiste landbouw op de daarvoor geschikte gronden' (zie het rapport Niet alles kan overal van het Adviescollege Stikstofproblematiek (Remkes et al., 2020)). Verder wordt met betrekking tot de ontwikkeling van agrarisch grondgebruik en het productieniveau van dierlijke sectoren aangesloten bij de studie Scenariostudie perspectief voor ontwikkelrichtingen Nederlandse landbouw in 2050 (Lesschen et al., 2020).

\section{S.2 Boodschap}

Primaire landbouw handhaaft zich in Nederland, met goede uitgangspositie voor verwerkende industrie In de vergroeningsscenario's zal ten minste $97 \%$ van de huidige primaire plantaardige productie en $77 \%$ van de dierlijke primaire productie overeind blijven en de productie van verwerkte producten groeit met minimaal $10 \%$. Agrarisch landgebruik blijft ten minste voor $86 \%$ in stand in alle scenario's en de afname wordt met name verklaard door bebouwing en extra land dat uit productie genomen wordt in kader van het biodiversiteitsbeleid.

Forse daling emissies in met name dierlijke sectoren

In alle vier scenario's leiden de vergroeningsmaatregelen tot sterke reductie van emissies. Emissies gerelateerd aan Nederlandse dierlijke productie dalen met 34\% indien de EU eenzijdig vergroent en $\mathrm{CO}_{2}$-eq-taks compenserende importtarieven worden geheven, tot $45 \%$ indien de hele wereld vergroent en de grenzen open zijn. Met name de $\mathrm{CO}_{2}$-eq-taks en dieetverandering zorgen voor reductie van emissies. Voor de plantaardige productie dalen broeikasgasemissies met $28 \%$ tot $35 \%$, ten opzichte van een daling van $24 \%$ in het referentiescenario. Het grootste deel wordt al in het referentiescenario gerealiseerd door onder andere technologische vooruitgang.

Productieontwikkeling in Nederland: dalende dierlijke productie door klimaatmaatregelen en dieetverandering, daling blijft beperkt bij compenserende grensmaatregelen, plantaardige productie groeit (gesloten wereld) of handhaaft zich (open wereld).

In alle vier scenario's vermindert de dierlijke productie (6\% tot $23 \%$ ). Dit wordt vooral veroorzaakt door de beprijzing van broeikasgasemissies en door vermindering van vleesconsumptie door dieetverandering. De plantaardige productie stijgt in de gesloten scenario's door dieetverandering en voorkeur voor lokale productie maar is stabiel in de liberalisatiescenario's. Wereldwijde reductie van voedselverspilling vermindert de vraag naar plantaardige producten. De voedselverwerkende industrie groeit iets ten opzichte van 2014 en de meeste vergroeningsmaatregelen hebben een beperkt negatief effect op het productievolume en toegevoegde waarde.
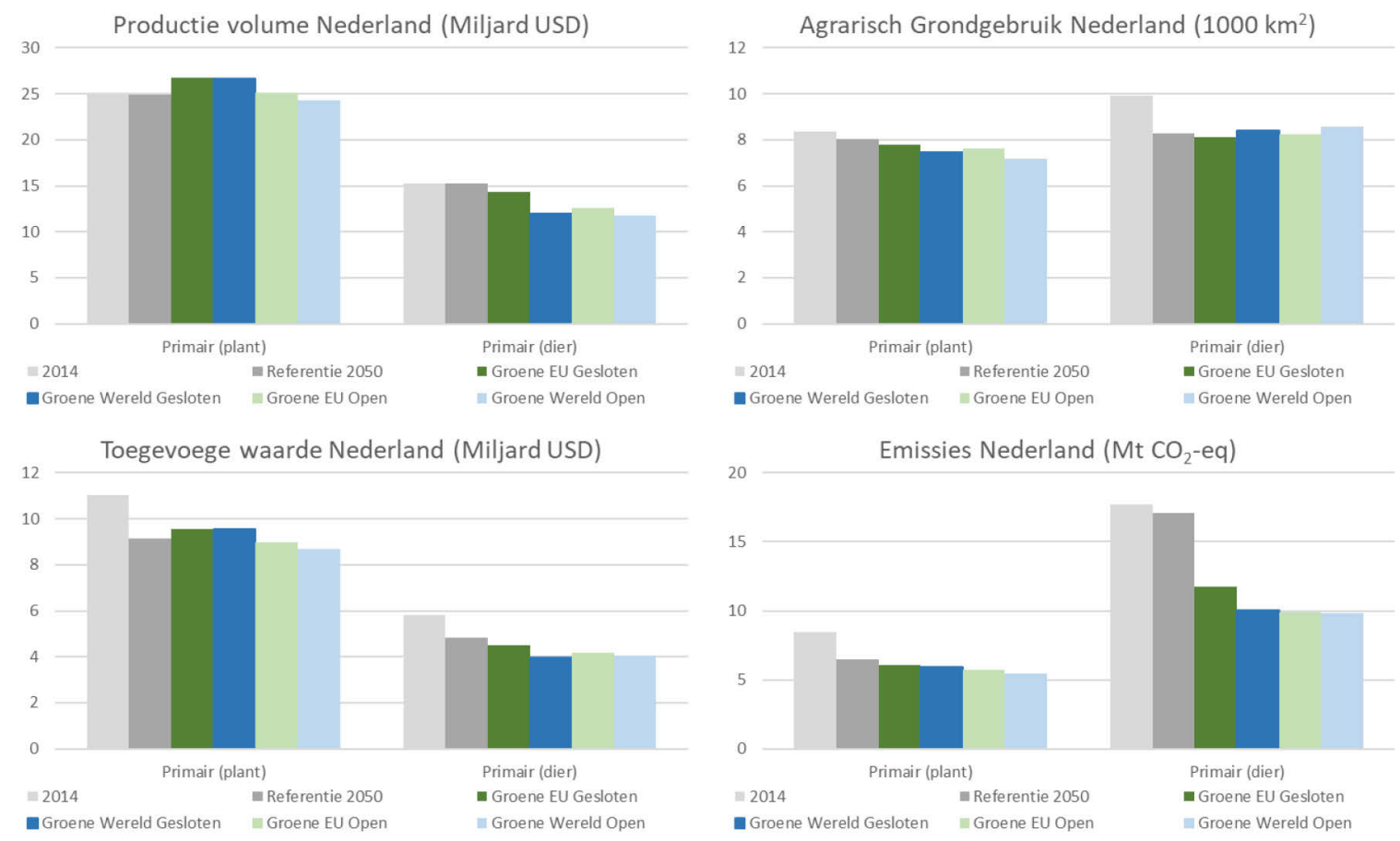
Afname grondgebruik voor landbouw volgens bestaande trend; mogelijk extensivering graslanden Het agrarische landgebruik daalt verder door beleid ter bevordering van natuur, maar blijft verder grotendeels in productie en valt in geen van de scenario's vrij. Grond wordt niet uit productie genomen, maar de lagere vraag naar agrarische producten leidt tot dalende grondprijzen. De akkerbouwgronden worden intensiever gebruikt terwijl graslanden extensiveren.

Beloning productiefactoren blijft achter bij rest economie

Door afname van de vraag zullen prijzen die producenten ontvangen voor hun producten en de toegevoegde waarde afnemen. Grondprijzen zijn een goede indicator voor de concurrentiekracht en economische gesteldheid van de agrarische sectoren. De grondprijs is stabiel ten opzichte van het referentiescenario indien de $\mathrm{EU}$ eenzijdig vergroent en $\mathrm{CO}_{2}$-eq-taks compenserende importtarieven worden geheven, maar daalt met $41 \%$ in het Groene Wereld Open scenario. In de andere twee scenario's is de daling $24 \%$ en $28 \%$. De beloningen voor alle productiefactoren dalen licht indien de EU alleen vergroent en markten beschermt, maar veel meer (15\% daling) indien de hele wereld vergroent met open markten. In de andere twee scenario's is de daling $10 \%$. De daling geldt met name voor de agrarische grondprijs en voor beloningen voor arbeid en kapitaal van boeren die bij voorkeur binnen de landbouw willen blijven werken.

Toegevoegde waarde: daling primaire sectoren, omvang voedselverwerkende industrie neemt toe In het referentiescenario daalt de toegevoegde waarde voor de primaire sectoren met $13 \%$ en stijgt deze met $16 \%$ voor de voedselverwerkende industrie. De daling in de primaire sectoren komt doordat de reële prijzen voor primaire agrarische producten blijven dalen en de productie bijna niet stijgt. In de vergroeningsscenario's is de daling van de toegevoegde waarde in de primaire sectoren tussen 83 en $68 \%$ van de huidige waarde. De toegevoegde waarde in voedselverwerkende industrie groeit met $12-24 \%$ en de relatieve omvang neemt toe van 55 tot $65 \%$. In de Groene EU-scenario's heeft de $\mathrm{CO}_{2}-$ eq-taks een groot negatief effect (9 à 10\%) op de toegevoegde waarde in de dierlijke sectoren terwijl in de Groene Wereld-scenario's dit effect beperkt is. Het grootste negatieve effect op de toegevoegde waarde in dierlijke sectoren wordt door dieetverandering veroorzaakt ( -13 à $-18 \%)$. Het Groene EU Gesloten-scenario is iets minder negatief dan de andere drie scenario's voor de Nederlandse dierlijke sectoren vanwege de compenserende importtarieven. De toegevoegde waarde in de plantaardige sectoren stijgt in de gesloten scenario's ten opzichte van de referentie omdat boven op de dieetverandering een sterkere voorkeur voor lokaal geproduceerd voedsel en compenserende tarieven een positief effect hebben.

\section{Beperkte effecten van vergroening op $B B P$}

De BBP-effecten van de vergroening in de landbouwsectoren zijn beperkt. De impact is 0,5\% tot bijna $1 \%$ negatief in de gesloten scenario's en het Groene EU Open-scenario ten opzichte van de referentie in 2050. Het Groene Wereld Open-scenario heeft zelfs een klein positief effect op BBP, wat wordt veroorzaakt doordat positieve effecten van handelsliberalisering en reductie van voedselverspilling opwegen tegen het negatieve effect van de $\mathrm{CO}_{2}$-eq-taks. Het effect van de $\mathrm{CO}_{2}$-eq-taks is negatief ter grootte van $2 \%$ à $3 \%$ in scenario's waarin de EU eenzijdig vergroent en ongeveer $1 \%$ indien overal ter wereld tegelijk de $\mathrm{CO}_{2}$-tax wordt ingevoerd. Het reduceren van voedselverspilling heeft in alle scenario's een positief effect op het BBP van driekwart procent. Handelsliberalisatie draagt ongeveer een half procent bij aan het BBP. Voorkeursverandering voor eigen producten draagt positief bij aan het BBP indien dit alleen in de EU plaatsvindt, maar heeft een negatief effect als dat ook in andere landen plaatsvindt.

\section{Handvatten voor beleid}

Vergroening van beleid raakt vooral de omvang van de dierlijke sectoren. De plantaardige sector handhaaft zich ongeveer op hetzelfde peil of groeit licht, afhankelijk van het scenario. De voedselverwerkende industrie neemt in relatieve betekenis toe, en floreert in de verschillende scenario's. Bij eenzijdige vergroening door de EU kunnen compenserende handelstarieven de negatieve invloed van $\mathrm{CO}_{2}$-eq-prijzen op de agrifoodsector beperken. Tijdig inzetten op verduurzaming kan op termijn een concurrentievoordeel opleveren, door hogere kosten in de toekomst te vermijden indien externe effecten mogelijk meer worden belast. In alle gevallen hebben de scenariovarianten geen noemenswaardige invloed op de zelfvoorzieningsgraad van voedsel in Nederland en de EU. De scenario's maken duidelijk dat er een vorm van afruil kan ontstaan. In het algemeen geldt dat 
wanneer de EU eenzijdig vergroent en de markten beschermt, de reductie in emissies het laagste is en de landbouw in Nederland het meest overeind blijft terwijl de daling in BBP beperkt is. Daarentegen leidt het scenario waarin de hele wereld vergroent en de grenzen open zijn tot de hoogste reducties in emissies maar zal de landbouw in Nederland het meeste dalen. Verduurzaming, vrijhandel, reductie van voedselverliezen en dieetveranderingen leiden tot een gunstige BBP-effect in dit scenario. Voor het halen van de wereldwijde klimaatdoelen is uiteindelijk wel wereldwijde vergroening noodzakelijk, want bij eenzijdige vergroening is het effect op emissies zeer beperkt. Voor Nederland zijn open grenzen dan mogelijk gewenst omdat dat ook tot een toename van het BBP kan leiden, maar dit scenario is dan wel minder gunstig voor de Nederlandse agrifoodsector. 


\section{Summary}

\section{S.1 Key issue}

This study gathered views of the potential future development of the Dutch agri-food sectors in the long term (up to and including 2050) and investigated what this could mean for the course of action of the Ministry of Agriculture, Nature and Food Quality. What are the possible consequences of several driving forces - as far as they are known today - that will determine the future of Dutch agriculture and horticulture? The starting point was a reference scenario: how will agriculture develop if policies do not change? Several variants were then considered. The variation is related to the degree of greening (implementation of the Paris Agreement/Green Deal) and whether this greening takes place unilaterally in the EU or also globally. Another variable is the extent to which trade is further liberalised.

In the greening scenarios, it is assumed that the pressure on the environment will be reduced by taxing greenhouse gas emissions, shifting to a more plant-based diet, reducing food waste, and providing more land for nature. The taxation of greenhouse gases will be implemented through a carbon dioxide equivalent tax $\left(\mathrm{CO}_{2}\right.$ eq. tax $)$ that approximates various expenditures that must be made to reduce emissions.

The variations in the degree of further trade liberalisation are extremely important for the Dutch agricultural sector since it is very export-oriented, yet also dependent on imports. There is uncertainty here as to whether international trade will be stimulated by further reductions in import tariffs, or whether it will be limited by variants of European trade policy with import tariffs that compensate for an internal $\mathrm{CO}_{2}$ eq. tax or because consumer preferences will shift towards local products. Such a shift could have various causes, such as a preference for sustainable products, the COVID-19 pandemic that makes imports from far away vulnerable, and other geopolitical developments that lead to further regionalisation.

These two uncertainties lead to the four scenarios (see Figure S.1). All the scenarios will be compared with a reference scenario in which there is no greening with respect to current policy. The MAGNET global general economic equilibrium model will be used for the implementation and quantification of the scenarios.

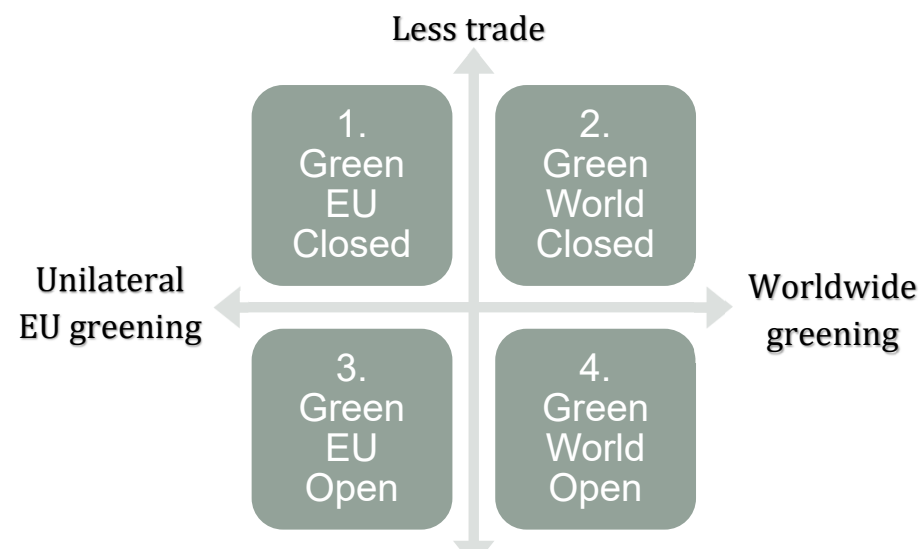

More trade

Figure S.1 Scenario table 
This study specifically examines the effects (both in terms of greening and trade policy) that these factors could have on production volumes, greenhouse gas emissions, added value, employment, production prices and the international trade position in the various scenarios. This long-term scenario study (2050) focuses on agriculture that produces for the European and world markets. It is assumed that the nitrogen problem will be addressed in the mid-term in accordance with spatial zoning based on the principle of 'the right agriculture on the right land' (see the report Niet alles kan overal (Not everything can be done everywhere) by the ministry's Advisory Committee on the Nitrogen Problem (Remkes et al., 2020)). With regard to developing agricultural land use and the production level of livestock sectors, the study is in line with the Scenariostudie perspectief voor ontwikkelrichtingen Nederlandse landbouw in 2050 (Scenario Study: Perspective for Development Directions for Dutch Agriculture in 2050; Lesschen et al., 2020).

\section{S.2 Message}

Primary agriculture will be preserved in the Netherlands, with a good starting position for the processing industry

In the greening scenarios, at least $97 \%$ of current primary crop production and $77 \%$ of primary livestock production will be maintained, and production of processed products will grow by at least $10 \%$. At least $86 \%$ of agricultural land use is maintained in all scenarios and the decline is mainly explained by cultivation and additional land taken out of production in connection with biodiversity policy.

Substantial decrease in emissions, especially in livestock sectors In all four scenarios, the greening measures lead to a sharp reduction in emissions. Emissions related to Dutch livestock production will decline by $34 \%$ if the $\mathrm{EU}$ unilaterally goes green and a $\mathrm{CO}_{2}$ eq. tax is imposed to offset import tariffs; that decline could be as large as $45 \%$ if the entire world goes green and borders are open. In particular, the $\mathrm{CO}_{2}$ eq. tax and dietary changes will reduce emissions. With regard to crop production, greenhouse gas emissions will decrease by $28-35 \%$ compared to a decrease of $24 \%$ in the reference scenario. Most of this is already achieved in the refence scenario by technological progress, among other things.

Production development in the Netherlands: declining livestock production due to climate measures and dietary changes, decline remains limited by compensatory border measures, crop production grows (closed world) or is maintained (open world).

Livestock production decreases in all four scenarios (by 6-23\%). This is mainly due to the taxation of greenhouse gas emissions and a reduction in meat consumption caused by dietary changes. Crop production increases in the closed scenarios due to dietary changes and a preference for local production, but it is stable in the liberalisation scenarios. Global food waste reduction decreases the demand for crop products. The food processing industry grows slightly compared to 2014 and most greening measures have a limited negative impact on production volume and added value. 

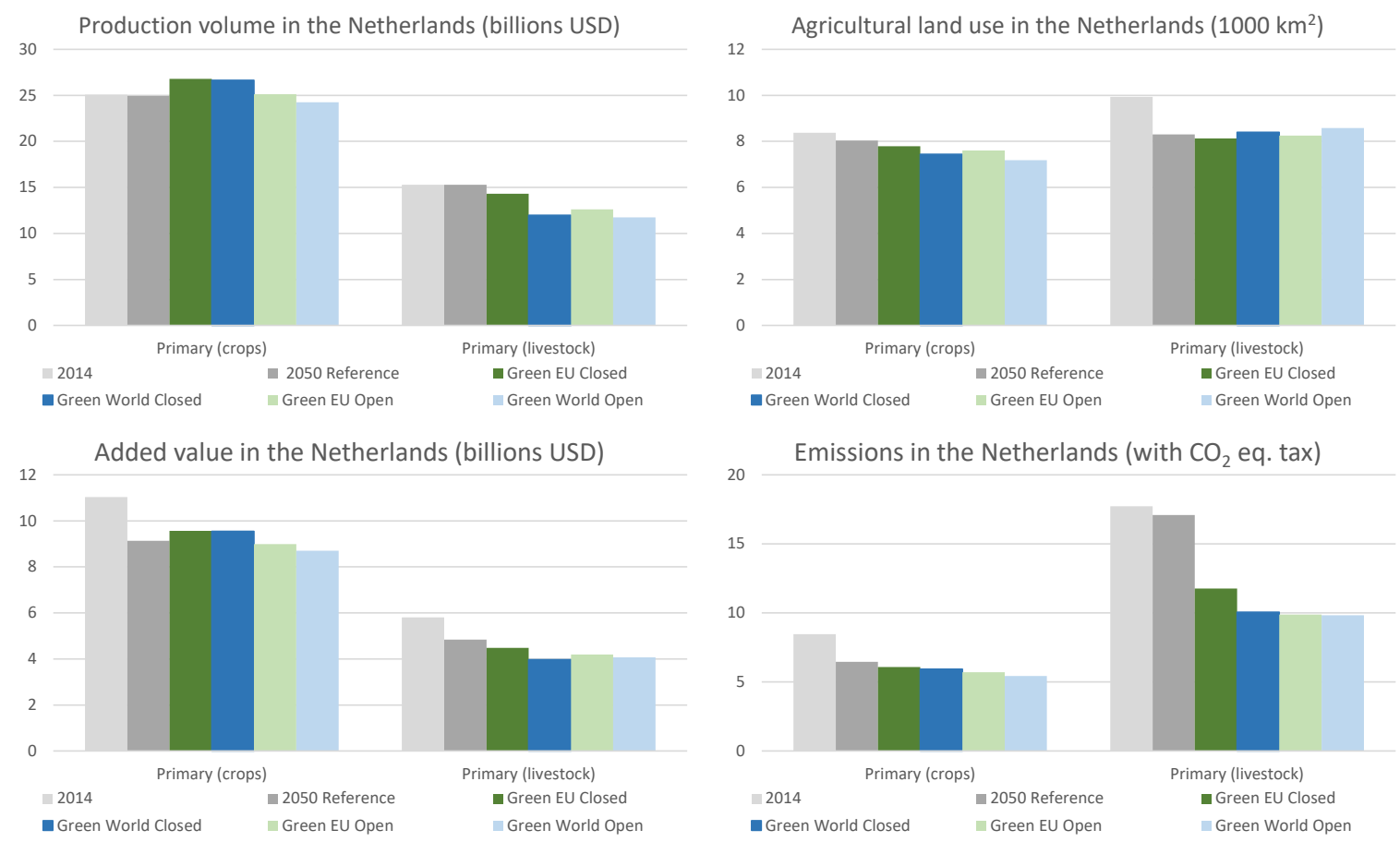

Decrease in land use for agriculture in line with existing trend; possible expansion of grasslands Agricultural land use continues to decline due to policies to promote nature, but it remains largely in production and is not set aside in any of the scenarios. Land is not taken out of production, but the lower demand for agricultural products leads to falling land prices. Arable land is used more intensively while grasslands are expanded.

\section{Remuneration for production factors lags behind the rest of the economy}

Falling demand will reduce added value and the prices producers receive for their products. Land prices are a good indicator of the competitiveness and economic condition of the agricultural sectors. The land price is stable compared to the reference scenario if the $\mathrm{EU}$ greens unilaterally and a $\mathrm{CO}_{2}$ eq. tax offsets import tariffs, but the land price drops by $41 \%$ in the Green World Open scenario. In the other two scenarios, the decrease is $24 \%$ and $28 \%$. The remunerations for all production factors decline slightly if the EU greens alone and protects markets, but they decline much more (15\%) if the entire world greens with open markets. In the other two scenarios, the decrease is $10 \%$. The decline particularly applies to agricultural land prices and to labour and capital remunerations for farmers who prefer to continue working in agriculture.

Added value: decrease in primary sectors, increase in the scale of the food processing industry In the reference scenario, added value declines by $13 \%$ for the primary sectors and increases by $16 \%$ for the food processing industry. The decline in the primary sectors is due to real prices for primary agricultural products continuing to fall while production barely rises. In the greening scenarios, the decrease in added value in the primary sectors is between $83 \%$ and $68 \%$ of the current value. The added value in the food processing industry grows by $12-24 \%$ and its relative size increases from $55 \%$ to $65 \%$. In the Green EU scenarios, the $\mathrm{CO}_{2}$ eq. tax has a large negative impact (9-10\%) on added value in the livestock sectors, while this impact is limited in the Green World scenarios. The largest negative impact on added value in livestock sectors is caused by dietary changes ( $-13 \%$ to $18 \%$ ). The Green EU Closed scenario is slightly less negative than the other three scenarios for the Dutch livestock sectors because of the compensatory import tariffs. Added value in the crop sectors is higher in the closed scenarios than in the reference scenario because, on top of the dietary change, a stronger preference for locally produced food and compensatory tariffs have a positive effect.

Limited effects of greening on GDP 
of trade liberalisation and reduction of food waste outweighing the negative effect of the $\mathrm{CO}_{2}$ eq. tax. The effect of the $\mathrm{CO}_{2}$ eq. tax is negative in the range of $2-3 \%$ in scenarios where the EU greens unilaterally and around $1 \%$ if the $\mathrm{CO}_{2}$ eq. tax is introduced simultaneously all over the world. Reducing food waste has a positive $0.75 \%$ effect on GDP in all scenarios. Trade liberalisation contributes about $0.5 \%$ to GDP. A change in preference for domestic products contributes positively to GDP if it takes place only in the EU, but it has a negative effect if it also takes place in other countries.

\section{Guidance for policy}

The greening of policies mainly affects the size of the livestock sectors. The crop sector remains at approximately the same level or grows slightly, depending on the scenario. The food processing industry increases in relative importance and flourishes in the different scenarios. If the EU greens unilaterally, compensatory trade tariffs may limit the negative impact of $\mathrm{CO}_{2}$ equivalent prices on the agri-food sector. A timely move towards sustainability could provide a competitive advantage in the long run, by avoiding higher costs in the future if externalities are potentially taxed more. In all cases, the scenario variants have no significant impact on the degree of food self-sufficiency in the Netherlands and the EU.

The scenarios make it clear that some form of trade-off may arise. In general, if the EU unilaterally greens and protects markets, the reduction in emissions will be the lowest and agriculture in the Netherlands will remain the most viable, while the decline in GDP will be limited. In contrast, the scenario in which the entire world becomes greener and borders are open leads to the greatest reductions in emissions but the greatest declines in Dutch agriculture. Sustainability, free trade, reduction of food losses and dietary changes lead to a favourable GDP effect in this scenario.

Ultimately, global greening will be needed to meet the global climate targets because unilateral greening will have an extremely limited effect on emissions. For the Netherlands, open borders may then be desirable because that could also lead to an increase in GDP, but this scenario would be less favourable for the Dutch agri-food sector. 


\section{$1 \quad$ Inleiding}

Deze verkenning vergaart beelden over de mogelijke toekomstige ontwikkeling van de Nederlandse agrifoodsectoren op de lange termijn (tot en met 2050) en wat die kunnen betekenen voor de handelingsperspectieven voor LNV. Wat zijn de mogelijke gevolgen van een aantal drijvende krachten - voor zover nu bekend - die de toekomst bepalen voor de Nederlandse land- en tuinbouw? Deze studie analyseert de gevolgen voor Nederland van vergroenings- en internationale handelsscenario's van de landbouw geïnspireerd op de Europese Green Deal en het Klimaatakkoord van Parijs. In de vergroeningsscenario's wordt de druk op het milieu verminderd door $\mathrm{CO}_{2}-, \mathrm{CH}_{4}-$ en $\mathrm{N}_{2} \mathrm{O}$ emissiebeprijzing, dieetverandering naar meer plantaardig eiwit, reductie van voedselverspilling, en meer grond voor natuur. Een belangrijke onzekerheid is of deze vergroeningsmaatregelen eenzijdig in de EU of ook mondiaal geïmplementeerd zullen worden. Internationale handel is cruciaal voor de zeer exportgerichte Nederlandse agrifoodsectoren die ook erg afhankelijk zijn van invoer uit de EU en de rest van de wereld. In de internationale handelsscenario's is het onzeker of de handel wordt geliberaliseerd door verdere verlaging van invoertarieven, of wordt beperkt door varianten van Europees handelsbeleid met importtarieven die een interne $\mathrm{CO}_{2}$-equivalententaks $\left(\mathrm{CO}_{2}\right.$-eq-taks) compenseren. Handel kan ook veranderen doordat consumentenvoorkeuren verschuiven naar lokale producten. Deze studie kijkt met name naar de gevolgen van deze factoren op productieomvang, broeikasgasemissies, toegevoegde waarde, werkgelegenheid, productieprijzen, en de internationale handelspositie. Deze scenariostudie op de lange termijn (2050) richt zich op de landbouw die voor de Europese en de wereldmarkt produceert. Er wordt van uitgegaan dat de stikstofproblematiek op de middellange termijn wordt aangepakt conform de ruimtelijke zonering op basis van het principe 'de juiste landbouw op de daarvoor geschikte gronden' (zie het rapport Niet alles kan overal van het Adviescollege Stikstofproblematiek (Remkes et al., 2020)).

Er worden in deze studie vier scenario's onderscheiden. Deze zijn ingedeeld op basis van twee kernonzekerheden. De eerste onzekerheid heeft betrekking op de vraag of alleen de EU vergroent (Groene EU) of ook de rest van de wereld (Groene Wereld). De tweede onzekerheid heeft betrekking op de internationale handel: vermeerdert de internationale handel door lagere invoer- en uitvoertarieven (Open) of vermindert de handel door een grotere voorkeur voor lokale producten en compenserende invoer- en uitvoertarieven in het geval van eenzijdige vergroening door de EU (Gesloten)? Alle scenario's worden vergeleken met een referentiescenario waarin geen vergroening ten opzichte van het huidige beleid plaatsvindt. 


\section{$2 \quad$ Algemene conclusies}

In alle vier scenario's leiden de vergroeningsmaatregelen tot sterke reductie van emissies. Emissies gerelateerd aan Nederlandse dierlijke productie dalen met 34\% indien de EU eenzijdig vergroent en $\mathrm{CO}_{2}$-eq-taks compenserende importtarieven worden geheven, tot $45 \%$ indien de hele wereld vergroent en de grenzen open zijn. Vergelijk dit met de $4 \%$ daling die in het referentiescenario optreedt. Met name de $\mathrm{CO}_{2}$-eq-taks en dieetverandering zorgen voor reductie van emissies. Voor de plantaardige productie dalen emissies met $28 \%$ tot $35 \%$, ten opzichte van een daling van $24 \%$ in het referentiescenario. In alle vier scenario's vermindert de dierlijke productie (6\% tot $23 \%$ ). Dit wordt vooral veroorzaakt door de beprijzing van broeikasgasemissies die een proxy zijn voor allerlei kosten die gemaakt dienen te worden om emissies te verlagen. Daarnaast is vermindering van de vraag door vermindering van vleesconsumptie door dieetverandering een belangrijke factor (13\%-18\%). Plantaardige productie stijgt in de gesloten scenario's door dieetverandering en voorkeur voor lokale productie maar is stabiel in de liberalisatiescenario's. Wereldwijde reductie van voedselverspilling vermindert de vraag naar plantaardige producten. De voedselverwerkende industrie groeit iets ten opzichte van 2014 en de meeste vergroeningsmaatregelen hebben een beperkt negatief effect op het productievolume en toegevoegde waarde. Bij vergroening zal de landbouw in Nederland blijven en worden landbouwgronden niet in grote mate uit productie genomen. De akkerbouwgronden worden intensiever gebruikt terwijl graslanden extensiveren.

Door afname van de vraag zullen prijzen die producenten ontvangen voor hun producten en de toegevoegde waarde afnemen. De beloningen voor productiefactoren in de agrarische sector zijn een soort thermometer voor de economische gezondheid van deze sector. Ze dalen licht (1\%) indien de EU alleen vergroent en markten beschermt, maar veel meer (15\% daling) indien de hele wereld vergroent met open markten. In de andere twee scenario's is de daling $10 \%$. De daling geldt met name voor de agrarische grondprijs en voor beloningen voor arbeid en kapitaal van boeren die bij voorkeur binnen de landbouw willen blijven werken.

Bij eenzijdige vergroening door de EU kunnen compenserende handelstarieven de negatieve invloed van $\mathrm{CO}_{2}$-eq-prijzen op de agrifoodsector beperken. Tijdig inzetten op verduurzaming kan op termijn een concurrentievoordeel opleveren, door hogere kosten in de toekomst te vermijden indien externe effecten mogelijk meer worden belast. In alle gevallen hebben de scenariovarianten geen noemenswaardige invloed op de zelfvoorzieningsgraad van voedsel in Nederland en de EU. Voor het halen van de wereldwijde klimaatdoelen is uiteindelijk wel wereldwijde vergroening noodzakelijk. Voor Nederland zijn open grenzen dan gewenst omdat dat ook tot een toename van het BBP kan leiden. Verduurzaming, vrijhandel, reductie van voedselverliezen en dieetveranderingen leiden tot een gunstig BBP-effect ten koste van de Nederlandse agroproductie. 


\section{Scenario's}

In de langetermijnscenario's, die lopen van basisjaar 2014 tot 2050, focussen we op twee kernonzekerheden gerelateerd aan enerzijds vergroening (milieu en klimaatbeleid) en anderzijds aan internationale handel. In het kader van de vergroening wordt ingezet op verlaging van $\mathrm{CO}_{2}{ }^{-}, \mathrm{CH}_{4}{ }^{-}$, en $\mathrm{N}_{2} \mathrm{O}$-uitstoot in de landbouw en is het de vraag of dit eenzijdig in de EU (met risico van weglekeffecten en negatieve effecten op de concurrentiepositie) of in samenhang met de hele wereld plaatsvindt. De onzekerheden omtrent internationale handel behelzen een meerdere of mindere mate van vrijhandel en de mogelijke verschuiving van consumentenvoorkeuren naar binnenlandse producten. Dit laatste kan mede veroorzaakt worden door de Covid-19-crisis waarin voorkeuren verschuiven naar binnenlandse (of binnen EU) productie vanwege de risico's van kwetsbare waardeketens, en overige geopolitieke ontwikkelingen die duiden op een tanend multilateralisme. Ook spelen zaken als voorkeur voor lokale producten vanwege duurzaamheid een rol. Een laatste mogelijke factor bij de handel is de mogelijkheid om bij eenzijdige vergroening een gelijk speelveld te creëren door de beprijzing van broeikasgassen te compenseren via invoertarieven.

In de analyse zullen de resultaten van de scenario's vaak ten opzichte van een 'business as usual'oftewel een referentiescenario bekeken worden. Het referentiescenario houdt geen rekening met de implementatie van de Green Deal en de daarbij horende verdere verduurzaming. Daarnaast wordt verondersteld dat het huidige landbouw-, handels- en ander beleid wordt gecontinueerd. In alle andere scenario's wordt voor de EU uitgegaan van vergroening ten opzichte van het referentiescenario.

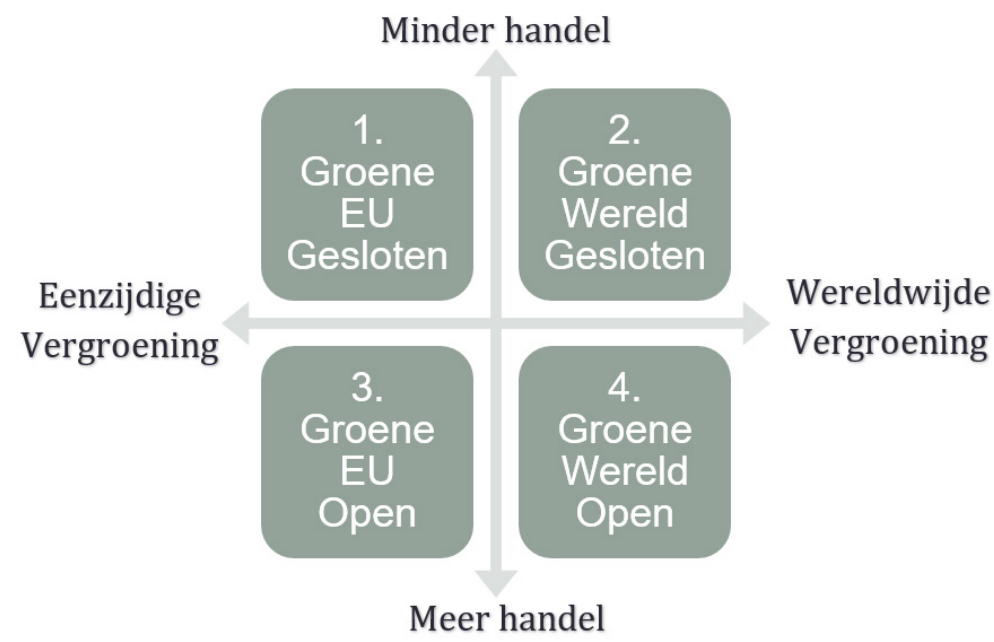

Figuur 3.1 Scenariomatrix

Gegeven de twee kernonzekerheden zien de vier vergroeningsscenario's er als volgt uit:

\section{Groene EU Gesloten}

Eenzijdige vergroening EU, minder vrijhandel tussen de EU en de rest van de wereld vanwege invoertarieven die de beprijzing van de emissies van broeikasgassen $\left(\mathrm{CO}_{2-}^{-}, \mathrm{CH}_{4}^{-}\right.$, en $\left.\mathrm{N}_{2} \mathrm{O}\right)$ compenseren. Ook wordt een voorkeursverandering voor lokale producten (binnen EU) verondersteld.

\section{Groene Wereld Gesloten}

Wereldwijde vergroening, minder vrijhandel door een hogere consumentenvoorkeur voor lokale producten. Voorkeur voor binnenlandse producten zowel in de EU als andere regio's in de wereld.

\section{Groene EU Open}

Eenzijdige vergroening EU, vrijere internationale handel door graduele afschaffing van invoer- en exporttarieven. 


\section{Groene Wereld Open}

Wereldwijde vergroening, vrijere internationale handel door graduele afschaffing van invoer- en exporttarieven.

\section{Implementatie scenario's}

Een mondiaal economisch modelraamwerk wordt gebruikt voor alle scenario's. Het raamwerk omvat het algemeen economische evenwichtsmodel MAGNET (Modular Applied GeNeral Equilibirum Tool, www.magnet-model.eu). Dit evenwichtsmodel geeft enerzijds agrarisch detail en biedt anderzijds een macro-economische invalshoek, inclusief wereldwijde bilaterale handelsstromen.

De basis voor het referentiescenario is het zogeheten 'Middle of the Road' oftewel 'Shared Socioeconomic Pathway 2' van het IPCC, die aannames voor het BBP, de bevolkingsgroei en de productiviteitsgroei verstrekt. Milieubeleid speelt een cruciale rol voor de toekomst van de Nederlandse agrifoodsectoren. Omdat we in deze studie niet specifiek op Nederlands milieubeleid focussen, en veel details van bijvoorbeeld het huidige mestbeleid niet expliciet in het MAGNET-model aanwezig zijn, wordt aangesloten bij de studie Scenariostudie perspectief voor ontwikkelrichtingen Nederlandse landbouw in 2050 (Lesschen et al., 2020). Deze studie laat zien dat de dierlijke productie vrij stabiel is in het referentiescenario vanwege de beperkte milieugebruiksruimte en daarom wordt er een productieplafond (milieu productie quota) voor dierlijke sectoren op basis van de huidige productieomvang verondersteld in deze studie. Ook wordt op basis van Lesschen et al. (2020) voor het referentiescenario aangenomen dat het totale agrarische grondgebruik autonoom, als continuering van historische trends, met 0,3\% per jaar zal dalen (i.e. -10,8\% tussen 2014 en 2050).

De vergroeningsmaatregelen zijn gekozen om deze te laten aansluiten bij een ' 2 graden en zo mogelijk 1,5 graden'-toekomst van het Klimaatakkoord van Parijs. Hoe Europa haar klimaatneutraliteit precies gaat bereiken (onder andere wat betreft verdeling tussen landen, sectoren en maatregelen) is nog niet exact bekend. Daarom worden deze maatregelen geïmplementeerd via een algemene broeikasgasprijs die gezien kan worden als een proxy voor de kostenverhoging als gevolg van allerlei maatregelen die in het algemeen voortvloeien uit klimaatbeleid. De hoogte van deze beprijzing is in lijn met een klimaatneutraal Europa en een wereldwijde 1,5-gradenambitie, met een stevige bijdrage vanuit de landbouwsectoren, zonder te garanderen dat die doelstelling gehaald wordt. De focus in deze studie is alleen op de agrifoodsectoren en de vergroening wordt met name bereikt door een prijs van USD 205 per ton $\mathrm{CO}_{2}$-equivalenten in 2050 voor alle sectoren en broeikasgassen, die gebaseerd is op studies die het gehele pakket van maatregelen economiebreed en wereldwijd hebben geïmplementeerd. Deze prijs is geïmplementeerd op zowel $\mathrm{CO}_{2}$ als methaan en lachgas (de drie belangrijkste broeikasgassen). Uit eerder onderzoek, op wereldschaal, is duidelijk dat bij de aangenomen prijs al een groot deel van de mogelijke reductie in broeikasgasemissies gerealiseerd wordt (Frank et al., 2018). Naast de algemene $\mathrm{CO}_{2}$-equivalentenbeprijzing worden er agrifoodspecifieke aannames gemaakt voor dieetverandering, reductie van voedselverspilling en bescherming van biodiversiteit.

In de scenario's met wereldwijde handelsliberalisatie worden de invoertarieven met $87,50 \%$ gereduceerd. Voor de scenario's met minder vrijhandel worden bij eenzijdige vergroening in de EU de invoertarieven zodanig verhoogd dat de broeikasgasprijzen gecompenseerd worden. Hierdoor worden de relatieve prijzen en concurrentiekracht van de Europese producenten op peil gehouden. Daarnaast wordt ook in de scenario's met 'minder handel' de voorkeur voor lokale consumptie met $20 \%$ verhoogd. Zie Tabel 3.1 voor een overzicht van alle aannames per scenario. 
Tabel 3.1 Overzicht aannames voor de vier scenario's

\begin{tabular}{|c|c|c|c|c|}
\hline & $\begin{array}{l}\text { 1. Groene EU } \\
\text { Gesloten: }\end{array}$ & $\begin{array}{l}\text { 2. Groene Wereld } \\
\text { Gesloten: }\end{array}$ & 3. Groene EU Open: & $\begin{array}{l}\text { 4. Groene Wereld } \\
\text { Open: }\end{array}$ \\
\hline & $\begin{array}{l}\text { Eenzijdige } \\
\text { verduurzaming EU, } \\
\text { minder vrijhandel }\end{array}$ & $\begin{array}{l}\text { Wereldwijde } \\
\text { verduurzaming, } \\
\text { minder vrijhandel }\end{array}$ & $\begin{array}{l}\text { Eenzijdige } \\
\text { verduurzaming EU, } \\
\text { meer vrijhandel }\end{array}$ & $\begin{array}{l}\text { Wereldwijde } \\
\text { verduurzaming, meer } \\
\text { vrijhandel }\end{array}$ \\
\hline $\begin{array}{l}\mathrm{CO}_{2} \text {-eq-taks } \\
\text { (Klimaatbeleid) }\end{array}$ & $\begin{array}{l}\text { EU CO} 2 \text {-eq-taks (USD } \\
205 / \text { ton in 2050) }\end{array}$ & $\begin{array}{l}\text { Wereldwijde } \mathrm{CO}_{2} \text {-eq- } \\
\text { taks (USD 205/ton in } \\
2050 \text { ) }\end{array}$ & $\begin{array}{l}\text { EU CO} 2 \text {-eq-taks (USD } \\
205 / \text { ton in 2050) }\end{array}$ & $\begin{array}{l}\text { Wereldwijde } \mathrm{CO}_{2} \text {-eq- } \\
\text { taks (USD 205/ton in } \\
2050 \text { ) }\end{array}$ \\
\hline Voedselverspilling & Reductie (33\%) in EU & $\begin{array}{l}\text { Reductie }(33 \%) \\
\text { wereldwijd }\end{array}$ & Reductie $(33 \%)$ in EU & $\begin{array}{l}\text { Reductie }(33 \%) \\
\text { wereldwijd }\end{array}$ \\
\hline Dieet & $\begin{array}{l}30 \% \text { minder vlees dan } \\
\text { in referentie scenario in } \\
\text { EU }\end{array}$ & $\begin{array}{l}30 \% \text { minder vlees dan } \\
\text { in referentiescenario } \\
\text { (wereldwijd exclusief } \\
\text { ontwikkelingslanden) }\end{array}$ & $\begin{array}{l}30 \% \text { minder vlees dan } \\
\text { in referentiescenario in } \\
\text { EU }\end{array}$ & $\begin{array}{l}30 \% \text { minder vlees dan } \\
\text { in referentie scenario } \\
\text { (wereldwijd exclusief } \\
\text { ontwikkelingslanden) }\end{array}$ \\
\hline Handel (Tarieven) & $\begin{array}{l}\mathrm{CO}_{2} \text {-eq-taks } \\
\text { compenserend } \\
\text { handelsbeleid in de EU }\end{array}$ & - & $\begin{array}{l}\text { Wereldwijde } \\
\text { handelsliberalisatie } \\
\text { ( } 87,50 \% \text { reductie } \\
\text { invoertarieven) }\end{array}$ & $\begin{array}{l}\text { Wereldwijde } \\
\text { handelsliberalisatie } \\
\text { ( } 87,5 \% \text { reductie } \\
\text { invoertarieven) }\end{array}$ \\
\hline Handel (Voorkeur) & $\begin{array}{l}20 \% \text { meer voorkeur } \\
\text { voor binnen EU } \\
\text { geproduceerde } \\
\text { producten in de EU }\end{array}$ & $\begin{array}{l}20 \% \text { meer voorkeur } \\
\text { voor producten in elke } \\
\text { regio }\end{array}$ & & - \\
\hline $\begin{array}{l}\text { Afname } \\
\text { landbouwgrond }\end{array}$ & $\begin{array}{l}\text { Extra bescherming land } \\
\text { zoals SSP1 voor EU }\end{array}$ & $\begin{array}{l}\text { Extra bescherming land } \\
\text { zoals SSP1 wereldwijd }\end{array}$ & $\begin{array}{l}\text { Extra bescherming land } \\
\text { zoals SSP1 voor EU }\end{array}$ & $\begin{array}{l}\text { Extra bescherming land } \\
\text { zoals SSP1 wereldwijd }\end{array}$ \\
\hline
\end{tabular}




\section{Resultaten}

De vergroeningsscenario's laten zien dat - binnen de gekozen aannames - de landbouw zeker niet uit Nederland zal verdwijnen. In alle scenario's zal ten minste $97 \%$ van de huidige primaire plantaardige productie en $77 \%$ van de dierlijke primaire productie overeind blijven en de productie van verwerkte producten groeit met minimaal $10 \%$. Agrarisch landgebruik blijft ten minste $86 \%$ in stand in alle scenario's en de afname wordt met name verklaard door bebouwing en extra land dat uit productie genomen wordt in kader van het biodiversiteitsbeleid.
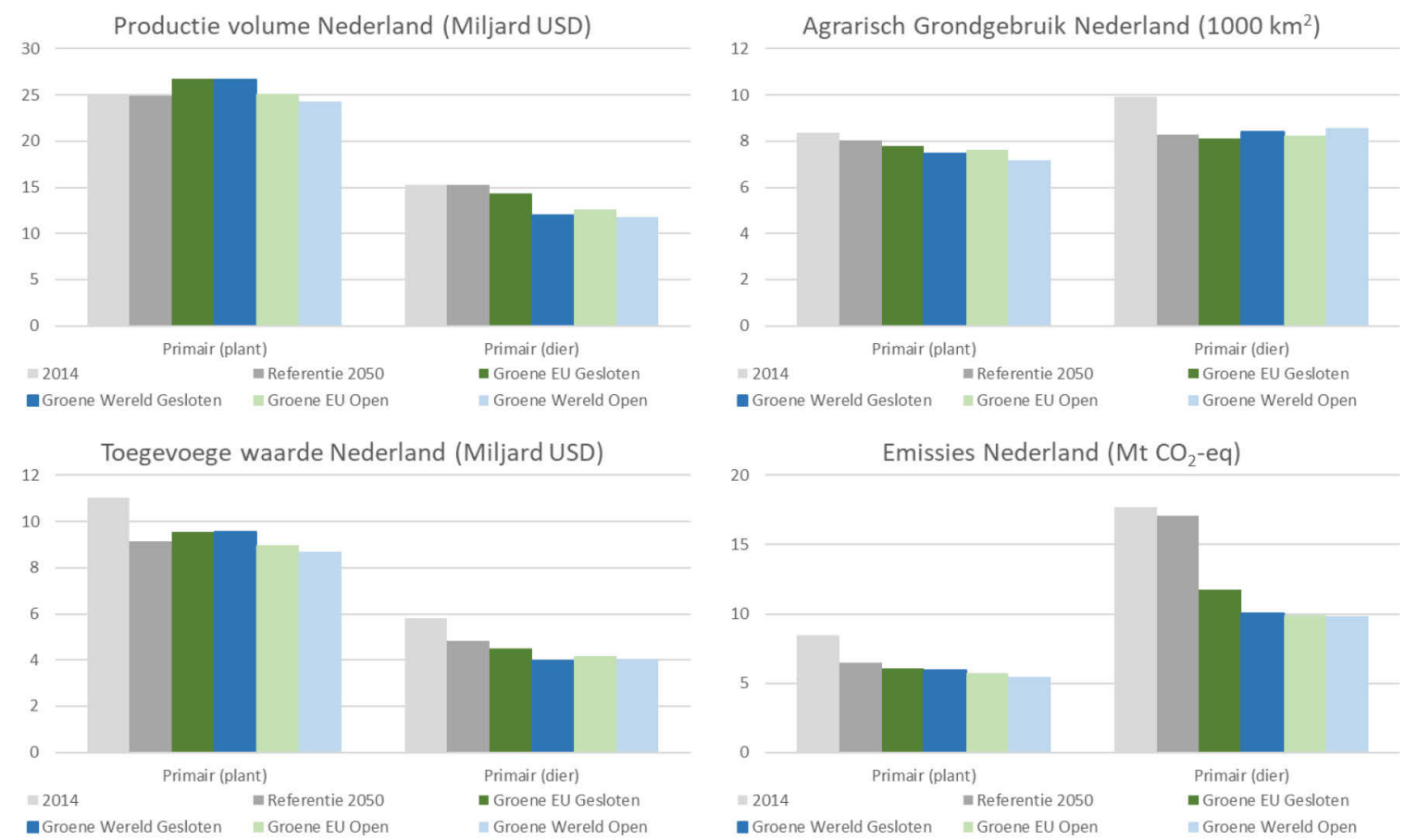

Figuur 4.1 Kernvariabelen Nederland

\section{Productie}

Onder alle scenario's is er een dalende dierlijke primaire productie in NEDERLAND (zie Figuur 4.1). Deze daling van de dierlijke productie varieert tussen de $6 \%$ en $23 \%$ en wordt met name gedreven door de $\mathrm{CO}_{2}$-eq-taks en dieetverandering, wat blijkt uit onderstaande Figuur 4.2 die het belang van de verschillende scenario-aannames weergeeft in een hittekaart. De impact van een $\mathrm{CO}_{2}$-eq-taks op primaire dierlijke productie is sterk negatief als de EU eenzijdig vergroent $(-16 \%,-18 \%)$. Daarnaast is de dierlijke productie sterk afhankelijk van het handelsbeleid, de reductie van voedselverspilling en of vergroeningsmaatregelen mondiaal al dan niet breed gedragen worden. Tarieven die de $\mathrm{CO}_{2}$-eq-taks compenseren aan de EU-grens en de voorkeur voor lokale producten verzachten de negatieve impact op productie en verhinderen weglekeffecten indien de EU eenzijdig vergroent (dierlijke productie daalt dan beperkt met $6 \%$ in Nederland). Hier speelt ook het effect van de beperkte milieugebruiksruimte op basis van bestaand milieubeleid een rol dat in het referentiescenario de potentiële uitbreiding op basis van wereldwijde vraag en aanbodontwikkelingen beperkt (zie Figuur 3.1). De productiedaling zou ten opzichte van het referentie scenario $16 \%$ lager zijn zonder dit effect. Dit effect speelt met name in Nederland waar het huidige milieubeleid knellend is. In de overige EU-landen waar dit effect van beperkte milieugebruiksruimte niet speelt, is de daling voor dierlijke productie ongeveer $20 \%$ ten opzichte van de $6 \%$ in Nederland. Indien de $\mathrm{CO}_{2}$-eq-taks compenserende tarieven worden afgeschaft en de handel iets meer liberaliseert, daalt de dierlijke productie met $18 \%$ (Groen EU Open scenario) in plaats van $6 \%$ (Groen EU Gesloten) in Nederland. Bij wereldwijde vergroening is het negatieve effect 
van de $\mathrm{CO}_{2}$-eq-taks veel lager (-7\% in plaats van $-16 \% /-18 \%$ bij alleen vergroening in $\left.\mathrm{EU}\right)$, maar daalt de dierlijke productie in Nederland met 22\%-23\% door dieetverandering waardoor de wereldwijde vraag naar vlees daalt, $(-20 \%,-21 \%)$. Ook krijgt Nederland geen concurrentievoordeel meer op basis van het reduceren van voedselverspilling. Het effect hiervan is $7 \%-8 \%$ hogere dierlijke productie bij eenzijdige vergroening EU aangezien dit tot lagere kosten leidt, maar is bij wereldwijde vergroening $-4 \%$. Het concurrentievoordeel bij eenzijdig terugdringen van de voedselverspilling in de $\mathrm{EU}$ is een overschatting doordat kosten om dit terug te dringen niet beschikbaar zijn en niet zijn meegenomen in deze studie.

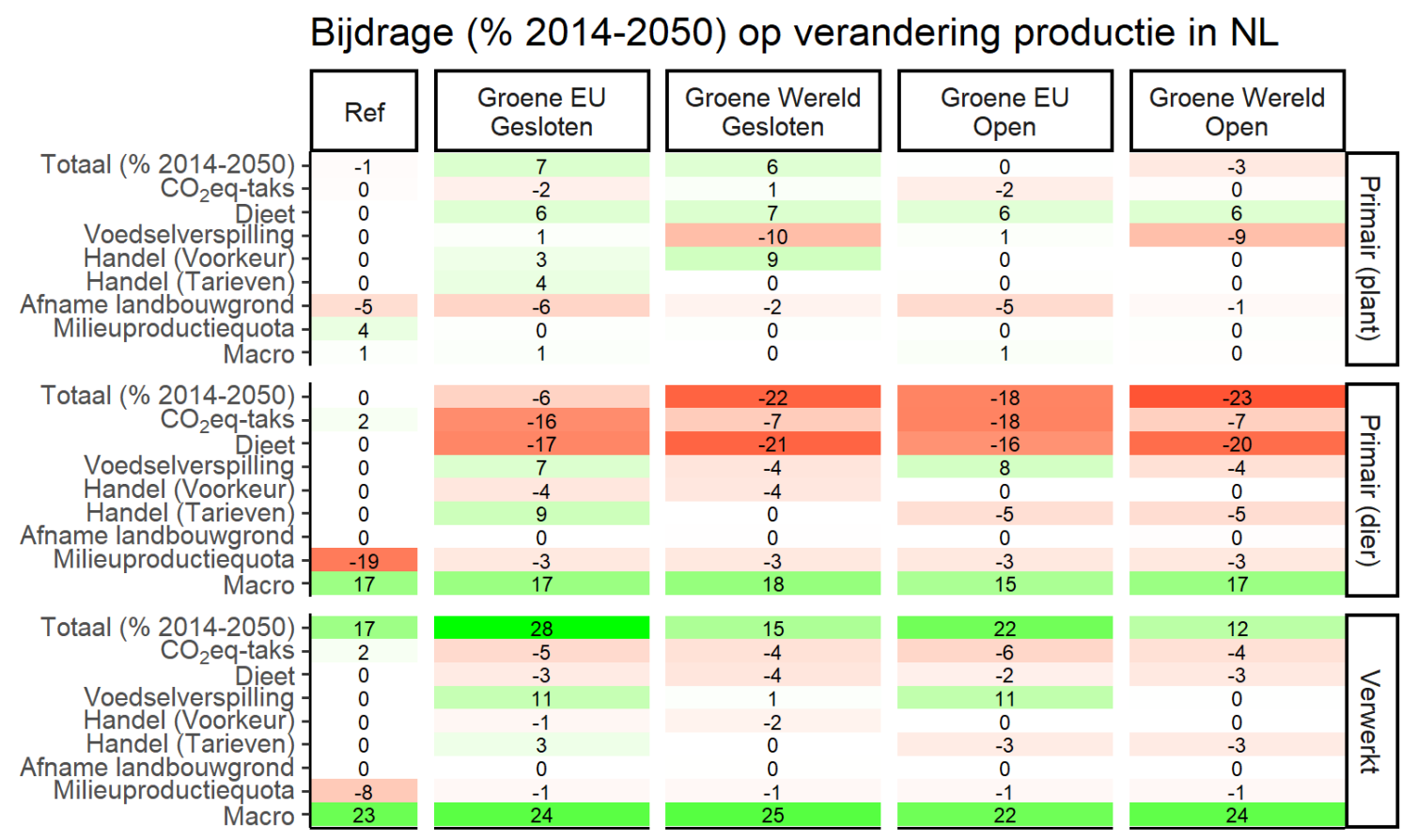

Figuur 4.2 Bijdrage scenarioaannames met betrekking tot verandering productie in NEDERLAND (\%). In deze decompositieanalyse wordt de bijdrage van de verschillende aannames op het uiteindelijke resultaat geschat (\% verandering 2014-2050). Onderscheiden worden het totale scenario-effect ('Totaal'), effect van USD 205 belasting op $\mathrm{CO}_{2}$-eq ('CO vleesconsumptie ('Dieet'), effect van 33\% minder voedselverspilling in de hele agrifoodketen ('Voedselverspilling'), 20\% meer voorkeur voor lokaal ('Handel (Voorkeur)'), $\mathrm{CO}_{2}$-compenserende invoertarieven of afschaffing invoertarieven ('Handel (Tarieven)'), afname van landbouwareaal door ontwikkelingen buiten de landbouw en door extra bescherming biodiversiteit ('Biodiversiteit') en macro-economische effecten (BBP, populatie) op basis van SSP2-scenario ('Macro').

Indien men meer in detail kijkt naar de sectoren, dan valt op dat binnen de dierlijke sectoren de melkveehouderij er positiever uitkomt dan de vleessectoren. De melkveehouderij krimpt meer als de vergroening wereldwijd is dan alleen binnen de EU ( $-11 \%$ tot $-18 \%$ versus, $-2 \%$ tot $-6 \%)$. Dit komt met name door dieetverandering, $\mathrm{CO}_{2}$-eq-taks, en de reductie van voedselverspilling die tot minder vraag leiden voor de sterk internationaal gerichte melkveehouderij. Vanwege de internationale gerichtheid van deze sector zijn de 'meer vrijhandel'-scenario's altijd gunstiger met betrekking tot productieontwikkeling dan de 'minder vrijhandel'-scenario's (4\% hogere productie in geval van EUscenario en $7 \%$ in geval van wereldwijd scenario). Voor de sterk met import concurrerende vleessectoren is dit beeld omgekeerd. Voor deze sectoren zijn de 'open handel'-scenario's bedreigender. In het geval dat de EU eenzijdig vergroent is de vermindering van vleesproductie $7 \%$ bij gesloten handel en $30 \%$ bij open handel. De compenserende $\mathrm{CO}_{2}$-invoerbelasting en de relatief hoge tariefbescherming spelen een grote rol in dit verschil. De wereldwijde scenario's zijn ook voor de vleessectoren negatiever omdat de vraag dan nog meer terugloopt door dieetverandering, vermindering van voedselverspilling en de $\mathrm{CO}_{2}$-eq-taks (zie Figuur 4.2 en ook Figuur, waar de effecten op wereldwijde productie getoond zijn). 
Plantaardige primaire productie groeit in de Gesloten Wereld-scenario's en stabiliseert of daalt licht in de Open Wereld-scenario's. Voor deze sectoren zijn er productiegroeimogelijkheden (6\% - $7 \%$ ) door de dieetverandering in alle scenario's (zie Figuur 4.2). In de gesloten scenario's wordt dit versterkt door onder andere een verschuiving in voorkeuren voor binnen de EU geproduceerde producten en in het Groene EU Gesloten-scenario door invoertarieven die de eenzijdige implementatie van de $\mathrm{CO}_{2}$-eqtaks compenseren. Hierbij speelt ook een rol dat er grond vrijkomt uit de dierlijke sectoren die nu voor plantaardige sectoren kan worden gebruikt.

De productie van de voedselverwerkende industrie groeit in de Groene EU-scenario's en daalt licht in de Groene Wereld-scenario's. Belangrijkste factor is dat door reductie van voedselverspilling de sterk internationaal gerichte voedselverwerkende industrie een concurrentievoordeel krijgt in de Groene EUscenario's en concurrerende regio's buiten de EU niet. Het is duidelijk dat dit gebaseerd is op de veronderstelling dat vermindering van voedselverspilling kan plaatsvinden zonder extra kosten.

\section{Landgebruik}

Ook het agrarische land blijft in productie en zal niet vrijvallen. De afname in de vergroeningsscenario's is 3\% meer dan in het referentiescenario (zie Figuur 4.1), wat komt door de extra aanname met betrekking tot extra bescherming biodiversiteit. De schaarste aan land, de hoge vruchtbaarheid en het intensieve gebruik houden de meeste landbouwgrond in productie, ook al leidt de dalende vraag in de groene scenario's tot een flinke daling van de grondprijs. Deze daling van de grondprijs leidt tot een lichte extensivering, met name van grasland (de grondproductiviteit in de melkveehouderij daalt met ongeveer $4 \%$ ten opzichte van het referentiescenario).

\section{Emissies}

Ervan uitgaand dat zowel $\mathrm{CO}_{2}$ als methaan en lachgas belast worden, is het voor de Nederlandse landbouw lonend om de emissie-intensiteit te doen dalen. Dit is geïmplementeerd met behulp van Marginal Abatement Cost (MAC-)curves die de kosten weergeven om emissie-intensiteiten te reduceren. Hoe hoger de $\mathrm{CO}_{2}$-eq-prijs, hoe meer technieken lonend worden.

De emissies van de totale primaire sector in Nederland dalen substantieel in alle vier scenario's, terwijl de daling in het referentiescenario beperkt is tot $10 \%$ in de 2014-2050 periode (zie Tabel 3.5). De daling ten opzichte van referentie in 2050, in het Groene EU Gesloten-scenario is 24\% terwijl deze in de andere drie scenario's in de orde van $32 \%-35 \%$ is. De $\mathrm{CO}_{2}$-eq-taks zorgt voor de grootste daling gevolgd door dieetveranderingen (zie Figuur 4.3). De grootste daling vindt plaats in de dierlijke sectoren $(-34 \%$ in Groene EU Gesloten, $-43 \%$ tot $-45 \%$ in andere scenario's tegenover $-4 \%$ in het referentiescenario). Opvallend is dat reductie van voedselverspilling leidt tot meer emissies in de scenario's waarin de EU eenzijdig vergroent maar tot minder emissies in de scenario's waar de gehele wereld vergroent. Reductie van voedselverspilling is vereenvoudigd geïmplementeerd als een productiviteitswinst, wat tot een betere concurrentiepositie leidt in de scenario's waarin de EU eenzijdig vergroent, waardoor de productie stijgt (zie ook Figuur 4.2). Bij de scenario's waarin de vergroening wereldwijd plaatsvindt is dit concurrentievoordeel afwezig en overheerst dat de wereldwijde vraag afneemt. De modeluitkomsten geven aan dat, in het geval van een eenzijdige vergroening in de EU, compenserende tarieven belangrijk zijn in het beschermen van de Nederlandse agrifoodsectoren, maar het voorkomt niet dat de dierlijke sector zal inkrimpen. Voor de plantaardige productie dalen emissies met $-28 \%$ tot $-35 \%$ ten opzichte van 2014 . Het grootste deel (23\%) wordt al in het referentiescenario gerealiseerd door onder andere technologische vooruitgang. In de vergroeningsscenario's spelen de $\mathrm{CO}_{2}$-eq-taks (-11\%--12\% in Groene EU-scenario's versus $-6 \%-8 \%$ in Groene Wereld-scenario's) en reductie voedselverspilling (-3\% in Groene EU-scenario's versus $-14 \%$ in Groene Wereld-scenario's) een grote rol bij de reductie terwijl dieetveranderingen (4\%-5\%), voorkeur lokale productie en tarieven de emissies juist verhogen. 


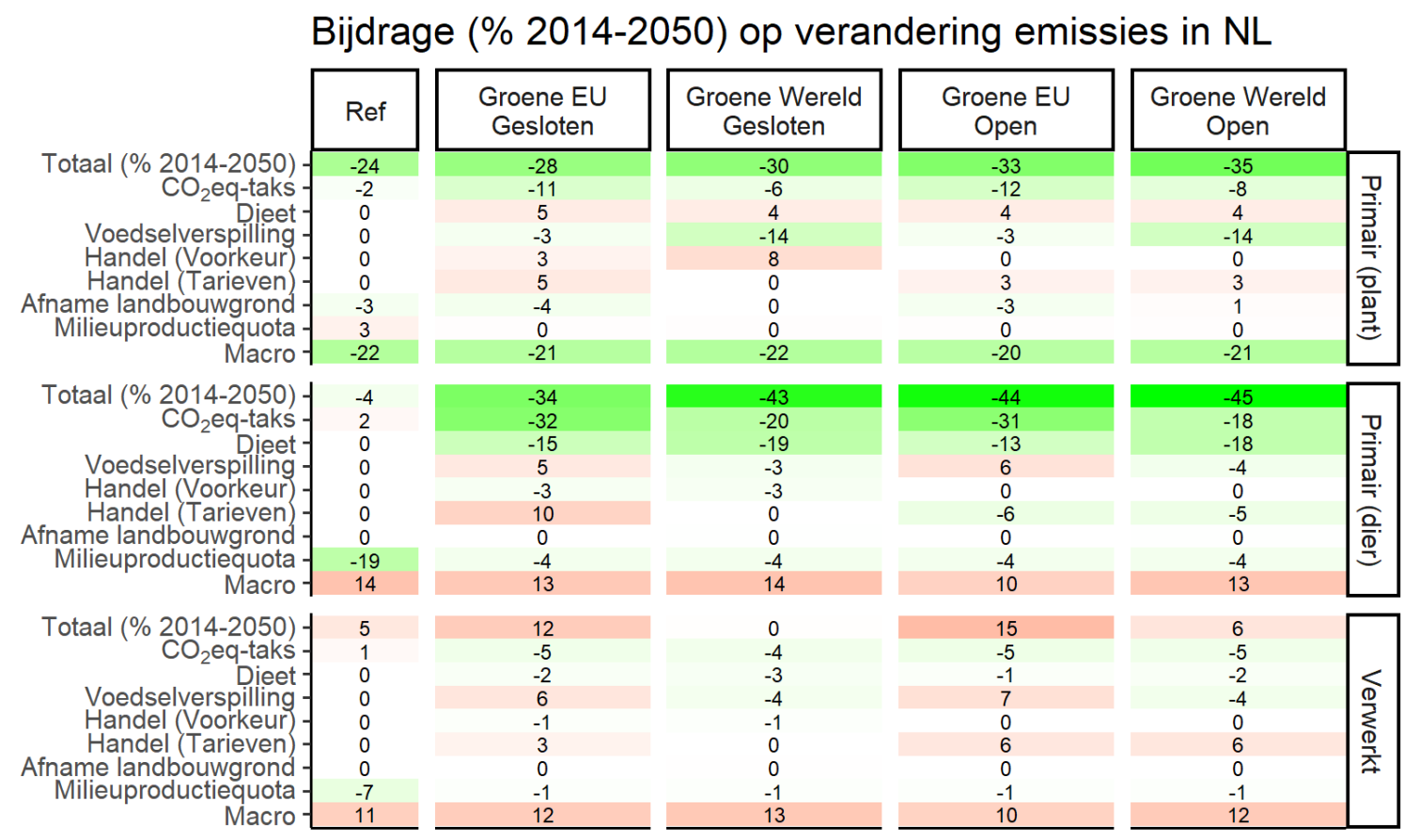

Figuur 4.3 Bijdrage scenarioaannames met betrekking tot verandering emissies in Nederland (\%)

Tabel 4.1 Prijzen productiefactor Nederland primaire sector (relatieve waarde in 2050, en (\% verandering ten opzichte van referentie in 2050))

\begin{tabular}{|c|c|c|c|c|c|c|}
\hline & 2014 & $\begin{array}{l}\text { 2050: } \\
\text { Referentie }\end{array}$ & $\begin{array}{l}\text { 2050: Groene } \\
\text { EU Gesloten }\end{array}$ & $\begin{array}{l}\text { 2050: Groene } \\
\text { Wereld Gesloten }\end{array}$ & $\begin{array}{l}\text { 2050: Groene } \\
\text { EU Open }\end{array}$ & $\begin{array}{l}\text { 2050: Groene } \\
\text { Wereld Open }\end{array}$ \\
\hline Land & 1 & 1,25 & $1,26(1 \%)$ & $0,9(-28 \%)$ & $0,95(-24 \%)$ & $0,74(-41 \%)$ \\
\hline $\begin{array}{l}\text { Geschoolde } \\
\text { arbeid }\end{array}$ & 1 & 1,12 & $1,11(-1 \%)$ & $1,06(-5 \%)$ & $1,06(-6 \%)$ & $1,02(-9 \%)$ \\
\hline Kapitaal & 1 & 0,68 & $0,66(-2 \%)$ & $0,64(-5 \%)$ & $0,63(-7 \%)$ & $0,61(-9 \%)$ \\
\hline Totaal & 1 & 0,94 & $0,93(-1 \%)$ & $0,84(-10 \%)$ & $0,84(-10 \%)$ & $0,78(-16 \%)$ \\
\hline
\end{tabular}

Toegevoegde waarde en beloningen productie factoren

In het referentiescenario daalt de toegevoegde waarde in primaire sectoren in Nederland tot $83 \%$ van huidige toegevoegde waarde voor zowel primaire plantaardige als dierlijke sectoren. Dit komt doordat de reële prijzen voor primaire agrarische producten blijven dalen en de productie bijna niet stijgt. In termen van beloningen van productiefactoren betekent dit dat de beloning voor productiefactoren in de primaire agrarische sectoren achterblijft ten opzichte van de rest van de economie. In het referentiescenario stijgen de lonen voor ongeschoolde en geschoolde arbeid met respectievelijk $5 \%$ en $12 \%$ in de primaire agrarische sector terwijl dit in de rest van de economie (inclusief voedselverwerkende industrie) $48 \%$ en $61 \%$ is (zie Tabel 3.1). Ten opzichte van het referentiescenario dalen de beloningen in de primaire agrarische sector voor arbeid en kapitaal licht ten opzichte van het referentiescenario (1\%-2\%) indien de EU alleen vergroent en markten beschermd worden. De daling van beloningen is veel groter ( $9 \%-10 \%)$ indien de hele wereld vergroent met open markten (zie Tabel 5.3). In de andere twee scenario's is de daling 5\% tot 7\%. Grond met agrarische bestemming wordt specifiek in de landbouw gebruikt en de beloningen worden daarom door ontwikkelingen binnen de landbouw bepaald. De grondprijs is daarom een stuk volatieler. Ze stijgt met $25 \%$ in het Referentiescenario. In het Groene EU Gesloten-scenario is de landprijs stabiel, maar daalt met $41 \%$ in het Groene Wereld Open-scenario en daalt met $24 \%$ tot $28 \%$ in de andere twee scenario's ten opzichte van het Referentiescenario in 2050. De bijna halvering van de grondprijs in het Groene Wereld Open-scenario ten opzichte van het Groene EU Gesloten-scenario leidt tot een daling van het grondaanbod in Nederland van slechts ongeveer $1 \%$. 
De relatieve omvang binnen de agrifoodsector van de voedselverwerkende industrie neemt toe. De toegevoegde waarde in voedselverwerkende industrie groeit met $12 \%-24 \%$ ( $16 \%$ in het referentiescenario) en doordat de toegevoegde waarde in primaire sectoren daalt neemt de relatieve omvang van voedselverwerkende industrie toe van $55 \%$ tot $65 \%$. In de Groene EU-scenario's heeft de $\mathrm{CO}_{2}$-eq-taks een groot negatief effect ( $9 \%$ à $\left.10 \%\right)$ op de toegevoegde waarde in de dierlijke sectoren terwijl in de Groene Wereld-scenario's dit effect beperkt is ( $1 \%$ à $2 \%$ ). Het grootste negatieve effect op de toegevoegde waarde in dierlijke sectoren wordt door dieetverandering veroorzaakt $(-13 \%$ a $-18 \%)$. Het Groene EU Gesloten-scenario is iets minder negatief dan de andere drie scenario's voor de Nederlandse dierlijke sectoren en leidt slechts tot een daling van $6 \%$ ten opzichte van het referentiescenario. De toegevoegde waarde in de plantaardige sectoren stijgt in de gesloten scenario's ten opzichte van de referentie omdat boven op de dieetverandering een sterkere voorkeur voor lokaal geproduceerd voedsel en compenserende tarieven een positief effect hebben (zie Figuur 4.4).

\section{Bijdrage (\% 2014-2050) op toegevoegde waarde in NL}

\begin{tabular}{|c|c|c|c|c|c|c|}
\hline & Ref & $\begin{array}{l}\text { Groene EU } \\
\text { Gesloten }\end{array}$ & $\begin{array}{l}\text { Groene Wereld } \\
\text { Gesloten }\end{array}$ & $\begin{array}{c}\text { Groene EU } \\
\text { Open }\end{array}$ & $\begin{array}{c}\text { Groene Wereld } \\
\text { Open }\end{array}$ & \\
\hline $\begin{array}{r}\text { Totaal (\% 2014-2050) } \\
\mathrm{CO}_{2} \text { eq-taks } \\
\text { Dieet } \\
\text { Voedselverspilling } \\
\text { Handel (Voorkeur) } \\
\text { Handel (Tarieven) } \\
\text { Afname landbouwgrond } \\
\text { Milieuproductiequota } \\
\text { Macro - }\end{array}$ & $\begin{array}{c}-17 \\
0 \\
0 \\
0 \\
0 \\
0 \\
-5 \\
4 \\
-16\end{array}$ & $\begin{array}{c}-13 \\
0 \\
6 \\
-3 \\
3 \\
3 \\
-6 \\
1 \\
-16\end{array}$ & $\begin{array}{c}-14 \\
1 \\
7 \\
-11 \\
8 \\
0 \\
-2 \\
1 \\
-17\end{array}$ & $\begin{array}{c}-19 \\
-1 \\
5 \\
-3 \\
0 \\
0 \\
-5 \\
1 \\
-16\end{array}$ & $\begin{array}{c}-21 \\
0 \\
6 \\
-11 \\
0 \\
0 \\
-1 \\
1 \\
-16\end{array}$ & 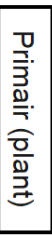 \\
\hline $\begin{array}{r}\text { Totaal (\% 2014-2050) } \\
\mathrm{CO}_{2} \text { eq-taks } \\
\text { Dieet } \\
\text { Voedselverspilling } \\
\text { Handel (Voorkeur) } \\
\text { Handel (Tarieven) } \\
\text { Afname landbouwgrond } \\
\text { Milieuproductiequota } \\
\text { Macro - }\end{array}$ & $\begin{array}{c}-17 \\
1 \\
0 \\
0 \\
0 \\
0 \\
-1 \\
-15 \\
-2\end{array}$ & $\begin{array}{c}-23 \\
-9 \\
-14 \\
2 \\
-4 \\
6 \\
-1 \\
-2 \\
-2\end{array}$ & $\begin{array}{l}-1 \\
-18 \\
-6 \\
-4 \\
0 \\
-2 \\
-2 \\
0\end{array}$ & $\begin{array}{l}-28 \\
-10 \\
-13 \\
3 \\
0 \\
-3 \\
-1 \\
-2 \\
-3\end{array}$ & $\begin{array}{c}-30 \\
0 \\
-17 \\
-6 \\
0 \\
-3 \\
-2 \\
-2 \\
0\end{array}$ & 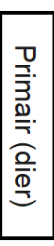 \\
\hline $\begin{array}{r}\text { Totaal (\% 2014-2050) } \\
\mathrm{CO}_{2} \text { eq-taks } \\
\text { Dieet } \\
\text { Voedselverspilling } \\
\text { Handel (Voorkeur) } \\
\text { Handel (Tarieven) } \\
\text { Afname landbouwgrond } \\
\text { Milieuproductiequota } \\
\text { Macro }\end{array}$ & $\begin{array}{c}16 \\
1 \\
0 \\
0 \\
0 \\
0 \\
0 \\
-6 \\
21\end{array}$ & $\begin{array}{r}24 \\
-3 \\
0 \\
5 \\
-1 \\
2 \\
0 \\
-1 \\
22 \\
\end{array}$ & $\begin{array}{c}12 \\
-4 \\
0 \\
-3 \\
-3 \\
0 \\
0 \\
-1 \\
22 \\
\end{array}$ & $\begin{array}{c}21 \\
-4 \\
0 \\
6 \\
0 \\
-1 \\
0 \\
-1 \\
20\end{array}$ & $\begin{array}{c}12 \\
-5 \\
0 \\
-3 \\
0 \\
-2 \\
0 \\
-1 \\
22 \\
\end{array}$ & 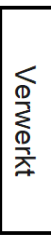 \\
\hline
\end{tabular}

Figuur 4.4 Bijdrage scenarioaannames met betrekking tot verandering toegevoegde waarde in Nederland (\% verandering 2014-2050). In het referentiescenario daalt de toegevoegde waarde voor de primaire sectoren met $13 \%$ en stijgt deze met $16 \%$ voor de voedselverwerkende industrie

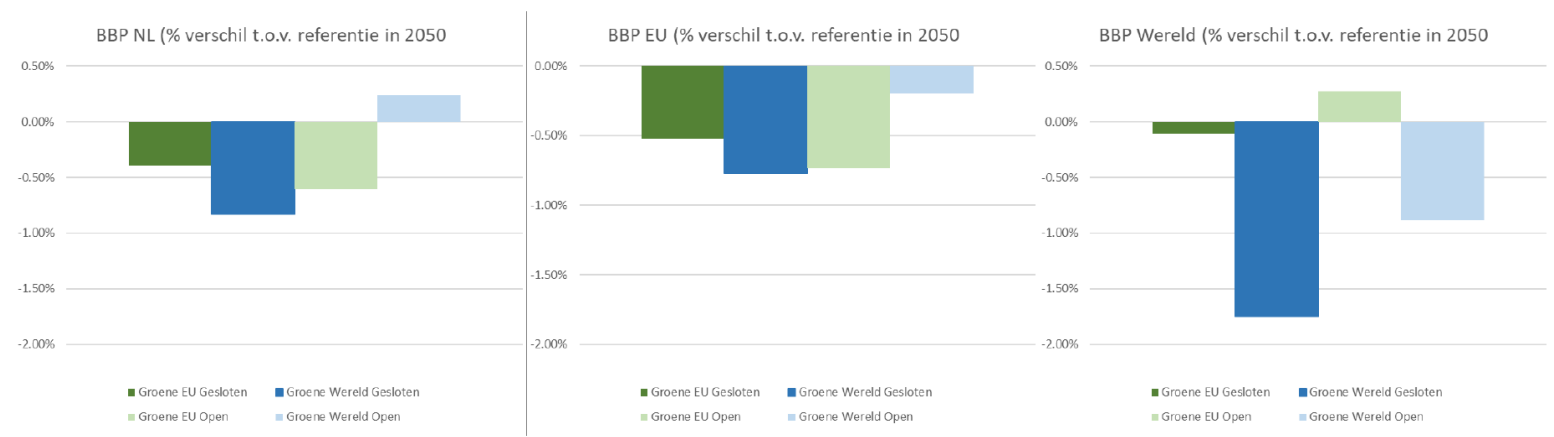

Figuur 4.5 BBP verandering ten opzichte van referentie in 2050

$B B P$

De BBP-effecten van de vergroening in de landbouwsectoren zijn beperkt. De totale BBP-groei van 77\% in de 2014-2050 periode wordt met name verklaard door macro-effecten (stijgende productiviteit en bevolkingsgroei). Het pakket aan veranderingen en aannames, die in onze scenario's alleen voor de agrifoodsector gelden, heeft slechts een beperkt effect ten opzichte van deze macro-effecten. De 
impact is $0,5 \%$ positief tot bijna $1 \%$ negatief in de gesloten scenario's en het 'Groene EU Open'scenario ten opzichte van de referentie in 2050 (zie Figuur 4.5). Het Groene Wereld Open-scenario heeft zelfs een klein positief effect op BBP wat wordt veroorzaakt doordat positieve handelsliberalisering effecten en de veronderstelde stijging van de productiviteit door reductie van voedselverspilling opwegen tegen het negatieve $\mathrm{CO}_{2}$-eq-takseffect. Figuur toont dat het $\mathrm{CO}_{2}$-eqtakseffect negatief is ter grootte van $2 \%$ à $3 \%$ in scenario's waarin de EU eenzijdig vergroent en ongeveer $1 \%$ indien overal ter wereld tegelijk de $\mathrm{CO}_{2}$-tax wordt ingevoerd. Het negatieve BBP-effect als de EU alleen vergroent is iets hoger in een open wereld dan in een gesloten wereld. Het reduceren van voedselverspilling heeft in alle scenario's een positief effect op het BBP van driekwart procent. Handelsliberalisatie draagt ongeveer een half procent bij aan het BBP. Voorkeursverandering voor eigen producten draagt positief bij aan het BBP indien dit alleen in de EU plaatsvindt, maar heeft een negatief effect als dat ook in andere landen plaatsvindt.

\section{Wereldwijde effecten}

Op wereldschaal daalt de productie alleen als er wereldwijd vergroeningsmaatregelen geïntroduceerd worden. Primair plantaardig en verwerkte industrie dalen qua productievolume met 3\% terwijl primair dier met ongeveer $25 \%$ daalt. De daling in dierlijke productie wordt met name veroorzaakt door dieetverandering (20\%), verhoging van de $\mathrm{CO}_{2}$-prijs (3\%) en reductie van voedselverspilling (2\%). Voldoen aan klimaatdoelen vergt wereldwijde inspanning. Als de EU eenzijdig vergroent, is het effect op wereldschaal beperkt (1\%-3\%). Compenserende tarieven verkleinen het weglekeffect maar resulteren ook in een beperktere daling van wereldwijde emissies. De wereldwijde vergroeningsmaatregelen zoals geïmplementeerd in deze scenario's reduceren emissies met $41 \%$ voor de primaire landbouw ten opzichte van het referentiescenario in 2050. 


\section{Beperkingen}

\section{Scenario's}

In deze studie wordt in het referentiescenario alleen bestaand beleid meegenomen en voor de scenario's een aantal generieke beleids- en strategische opties. Sectorspecifieke klimaatopties worden niet expliciet meegenomen en een verdere expliciete inkrimping van de milieuruimte, in het kader van onder andere het stikstofdebat, wordt niet expliciet verondersteld. Verder is er onzekerheid met betrekking tot de $\mathrm{CO}_{2}$-prijzen, aangezien sinds de start van deze studie, de $\mathrm{CO}_{2}$-prijs gestegen is van circa $€ 25$ per ton naar $€ 50$ per ton, wat het niveau is waar we in deze studie in 2030 van uitgaan. Daarnaast worden er in de sectoren buiten de landbouw geen extra vergroenings- of handelsmaatregelen geïmplementeerd.

\section{Implementatie}

De reductie van voedselverspilling is geïmplementeerd als een stijging van de productie-efficiëntie en een daling van vraag bij consumenten. Dit is echter gedaan zonder rekening te houden met eventuele kosten aangezien inzicht in het kostenplaatje ontbreekt. Meer inzicht in de kosten om de beoogde reductie van voedselverspilling mogelijk te maken is noodzakelijk om een betere inschatting te maken van de gevolgen van het terugdringen van voedselverspilling. Implementatie van het kostenplaatje zou het concurrentievoordeel in de Groene EU-scenario's kleiner maken. Ook bij de dieetverandering is het de vraag of het doel van $60 \%$ plantaardige proteïne realistisch is. Het is in lijn met de SSP1aannames, maar $50 \%$ wordt al als ambitieus gezien.

\section{Model}

De dekking is goed voor de grondgebonden sectoren en intensieve veehouderij maar minder goed voor de typisch Nederlandse sectoren zoals sierteelt, bomen en bollen. Om uitspraken over gedetailleerde sectoren te doen dienen sectoren in MAGNET opgesplitst te worden of moet er een samenwerking aangegaan worden met meer gedetailleerde agrarische sectormodellen. MAGNET is een wereldwijd model maar kent geen regionale detaillering binnen Nederland. Voor bestudering stikstofproblematiek in een wereldwijde context dient MAGNET in combinatie met ruimtelijk expliciete modellen te worden gebruikt. Verder dienen de emissie-intensiteiten op gedetailleerd sectorniveau gevalideerd en geüpdatet te worden en met name de verhouding hiervan ten opzichte van andere exporterende en importerende landen. De specifieke Nederlandse situatie met een groot tuinbouwbelang dient verbeterd te worden op het gebied van de emissiedata. Verder is het van belang om de opsplitsing van sectoren in het model beter aan te laten sluiten bij het belang van sectoren in de Nederlandse economie. Een beperking is ook de implementatie van mitigatie maatregelen via de marginal abatement cost (MAC-)curves die een stilistische weergave van de werkelijkheid behelst en expliciete representatie van mitigatiemaatregelen de voorkeur geniet. Ten minste dienen deze curves gevalideerd te worden op basis van micro-economische en technische studies en meer toegespitst te worden op de Nederlandse situatie. Het is duidelijk dat de mate waarin de reductie van emissieintensiteit behaald wordt van cruciaal belang is voor de weerbaarheid van de Nederlandse landbouweconomie in een sterk vergroenende wereld. 


\section{Literatuur en websites}

Doelman, J. C., Stehfest, E., Tabeau, A., van Meijl, H., Lassaletta, L., Gernaat, D. E. H. J., Neumann-Hermans, K., Harmsen, M., Daioglou, V., Biemans, H., van der Sluis, S., \& van Vuuren, D. P. (2018). Exploring SSP land-use dynamics using the IMAGE model: Regional and gridded scenarios of land-use change and land-based climate change mitigation. Global Environmental Change, 48, 119-135. https://doi.org/10.1016/j.gloenvcha.2017.11.014

Frank, S., Havlík, P., Stehfest, E., Meijl, H. van, Witzke, P., Pérez-Domínguez, I., Dijk, M. van, Doelman, J. C., Fellmann, T., Koopman, J. F. L., Tabeau, A., \& Valin, H. (2018). Agricultural non$\mathrm{CO} 2$ emission reduction potential in the context of the $1.5^{\circ} \mathrm{C}$ target. Nature Climate Change 2018 9:1, 9(1), 66-72. https://doi.org/10.1038/s41558-018-0358-8

Hasegawa, T., Fujimori, S., Havlík, P., Valin, H., Bodirsky, B. L., Doelman, J. C., Fellmann, T., Kyle, P., Koopman, J. F. L., Lotze-Campen, H., Mason-D'Croz, D., Ochi, Y., Pérez Domínguez, I., Stehfest, E., Sulser, T. B., Tabeau, A., Takahashi, K., Takakura, J., van Meijl, H., ... Witzke, P. (2018). Risk of increased food insecurity under stringent global climate change mitigation policy. Nature Climate Change, 8(8). https://doi.org/10.1038/s41558-018-0230-x

Keramidas, K., Tchung-Ming, S., Diaz-Vazquez, A. R., Weitzel, M., Vandyck, T., Després, J., Schmitz, A., Rey Los Santos, L., Wojtowicz, K., Schade, B., Saveyn, B., \& Soria-Ramirez, A. (2018). Global Energy and Climate Outlook 2018: Sectoral mitigation options towards a lowemissions economy - Global context to the EU strategy for long-term greenhouse gas emissions reduction. Publications Office of the European Union, 200. https://doi.org/10.2760/67475

Lesschen, J. P., Reijs, J., Vellinga, T., Verhagen, J., Kros, H., de Vries, M., Jongeneel, R., Slier, T., Gonzalez Martinez, A., Vermeij, I., \& Daatselaar, C. (2020). Scenariostudie perspectief voor ontwikkelrichtingen Nederlandse landbouw in 2050. Wageningen Environmental Research. https://doi.org/10.18174/512111

O'Neill, B. C., Kriegler, E., Ebi, K. L., Kemp-Benedict, E., Riahi, K., Rothman, D. S., van Ruijven, B. J., van Vuuren, D. P., Birkmann, J., Kok, K., Levy, M., \& Solecki, W. (2017). The roads ahead: Narratives for shared socioeconomic pathways describing world futures in the 21st century. Global Environmental Change, 42, 169-180. https://doi.org/10.1016/j.gloenvcha.2015.01.004

Philippidis, G., Shutes, L., M'Barek, R., Ronzon, T., Tabeau, A., \& van Meijl, H. (2020). Snakes and ladders: World development pathways' synergies and trade-offs through the lens of the Sustainable Development Goals. Journal of Cleaner Production, 267, 122147. https://doi.org/10.1016/j.jclepro.2020.122147

Rogelj, J., Popp, A., Calvin, K. V., Luderer, G., Emmerling, J., Gernaat, D., Fujimori, S., Strefler, J., Hasegawa, T., Marangoni, G., Krey, V., Kriegler, E., Riahi, K., Van Vuuren, D. P., Doelman, J., Drouet, L., Edmonds, J., Fricko, O., Harmsen, M., ... Tavoni, M. (2018). Scenarios towards limiting global mean temperature increase below $1.5^{\circ} \mathrm{C}$. Nature Climate Change, 8(4), 325-332. https://doi.org/10.1038/s41558-018-0091-3

van Vuuren, D. P., Stehfest, E., Gernaat, D. E. H. J., Doelman, J. C., van den Berg, M., Harmsen, M., de Boer, H. S., Bouwman, L. F., Daioglou, V., Edelenbosch, O. Y., Girod, B., Kram, T., Lassaletta, L., Lucas, P. L., van Meijl, H., Müller, C., van Ruijven, B. J., van der Sluis, S., \& Tabeau, A. (2017). Energy, land-use and greenhouse gas emissions trajectories under a green growth paradigm. Global Environmental Change, 42, 237-250. https://doi.org/10.1016/j.gloenvcha.2016.05.008

Weitzel, M., Vandyck, T., Keramidas, K., Amann, M., Capros, P., den Elzen, M., Frank, S., Tchung-Ming, S., Díaz Vázquez, A., \& Saveyn, B. (2019). Model-based assessments for long-term climate strategies. In Nature Climate Change (Vol. 9, Issue 5, pp. 345-347). Nature Publishing Group. https://doi.org/10.1038/s41558-019-0453-5

Westhoek, H. (2019). Kwantificering van de effecten van verschillende maatregelen op de voetafdruk van de Nederlandse voedselconsumptie, Den Haag: PBL. https://www.pbl.nl/publicaties/kwantificering-van-de-effecten-van-verschillende-maatregelen-opde-voetafdruk-van-de-nederlandse-voedselconsumptie 


\section{Bijlage 1 Modeltechnische achtergrond}

\section{B1.1 Introductie}

\section{B1.1.1 Achtergrond \& doelstelling}

In het verleden liet LNV periodiek onderzoek verrichten naar de toekomst van de landbouw in Nederland via scenariostudies. De laatste studie verscheen in 2011. Deze onderzoeken betroffen modelmatige verkenningen van de toekomst en het LEI (nu Wageningen Economic Research) gebruikte daarvoor modellen waar zowel de mondiale, als de Europese en nationale stand van zaken en ontwikkelingen werden gepresenteerd en met elkaar verbonden. Wageningen Economic Research is nog steeds actief in het wereldwijde consortium dat het mondiale model (GTAP) actief beheert en verder ontwikkelt. De Wageningen Economic Research-variant van dit model met een focus op de agrifood (bio-economie) sectoren is de Modular Applied General Equilibrium Tool (MAGNET). ${ }^{1}$

MAGNET is een economisch evenwichtsmodel waar inmiddels verscheidene niet-economische parameters mee zijn verbonden. Bijvoorbeeld de relatie tussen handel en klimaat, maar ook de implicaties van beide thema's voor de voedselzekerheid. In ieder geval is het mogelijk variabele condities voor de handel te modelleren, zoals bijvoorbeeld meer of minder vrijhandel of voorkeur voor lokale producten. Op die manier zijn ook de effecten van geopolitieke ontwikkelingen (bijvoorbeeld handelsoorlogen en de consequenties daarvan) of stokkende handelsstromen door bijvoorbeeld uitbraken van pandemieën met het model door te rekenen.

De verkenning met behulp van dit model in deze studie heeft primair tot doel om beelden te vergaren over de mogelijke toekomstige ontwikkeling van de Nederlandse agrifoodsectoren op de lange termijn en wat dit kan betekenen voor de handelingsperspectieven voor LNV. Hiertoe zijn vergroeningsscenario's en varianten van handelsbeleid opgezet en de effecten voor Nederland, EU, en wereldwijd geanalyseerd in scenario's lopend tot 2050.

\section{B1.1.2 Probleemstelling}

Deze verkenning vergaart beelden over de mogelijke toekomstige ontwikkeling van de Nederlandse agrifoodsectoren op de lange termijn (tot en met 2050) en wat dit kan betekenen voor de handelingsperspectieven voor LNV. Wat zijn de mogelijke gevolgen van een aantal drijvende krachten - voor zover nu bekend - die de toekomst bepalen voor de Nederlandse land- en tuinbouw? Deze studie analyseert de gevolgen voor Nederland van vergroeningsscenario's van de landbouw, waarin druk op het milieu verminderd wordt door $\mathrm{CO}_{2}$-beprijzing, dieetverandering naar meer plantaardig eiwit, reductie van voedselverspilling, en meer grond voor natuur. We bekijken varianten van Europees handelsbeleid met $\mathrm{CO}_{2}$-eq-taks compenserende importtarieven, consumentenvoorkeuren voor lokale producten, en of de vergroeningsmatregelen eenzijdig in de EU of ook mondiaal breed geïmplementeerd zullen worden. Deze studie kijkt met name naar de gevolgen van deze factoren op omvang, toegevoegde waarde, werkgelegenheid, productieprijzen, internationale handelspositie en broeikasgasemissies.

\section{B1.1.3 Methodologie}

Een economisch modelraamwerk wordt gebruikt voor alle scenario's. Dit type raamwerk is onder andere toegepast in LNV-studies (bijvoorbeeld 'In perspectief' (2011) en ons onderzoek in 2020 naar de effecten van Covid-19) en de SCENAR2020-studies voor DGAgri (Nowicki et al. 2009). Het raamwerk omvat het mondiale economische evenwichtsmodel MAGNET. Dit model wordt beheerd en ontwikkeld door een wereldwijd (Global Trade analysis Project, GTAP) consortium, waar Wageningen

1 https://www. magnet-model.eu/ 
Economic Research sinds 1997 partner van is. Het MAGNET-model is een wereld bilateraal handelsmodel, met keuze uit 140 landen/regio's die tezamen werelddekkend zijn, en dekt de hele economie maar met focus op landbouw en gerelateerde sectoren (e.g. Woltjer et al. 2014, Van Meijl et al. 2016, 2018, 2020). Dit evenwichtsmodel geeft enerzijds agrarisch detail en anderzijds de macro-economische invalshoek, inclusief wereldwijde bilaterale handelsstromen. De focus op landbouw komt onder andere tot uiting in het expliciete modelleren van grondmarkten, productiequota en gesegmenteerde markten van productiefactoren tussen landbouw en overige sectoren. Dit laatste impliceert dat fysiek kapitaal of een arbeidskracht niet direct kan overgaan van de landbouw naar andere sectoren vanwege landbouwspecifieke vaardigheden. Hierdoor kunnen lonen verschillen tussen landbouw en overige sectoren.

Voor de Nederlandse agrosectoren worden de resultaten voor een reeks indicatoren beschreven, zoals:

- Bruto binnenlands product (BBP)

- Internationale handel (import, export, netto handelsbalans)

- Omvang sectoren (opbrengsten)

- Toegevoegde waarde sectoren (vergoeding voor arbeid, kapitaal en grond)

- Prijzen van inputs, producten en productiefactoren (land, arbeid, kapitaal)

- Werkgelegenheid

- Landgebruik

- Broeikasgasemissies

Deze indicatoren worden berekend voor Nederland en de geselecteerde overige regio's en sectoren (zie sectie 0 ).

\section{B1.2 Scenario's en opzet model}

\section{B1.2.1 Aanpak scenario-opzet}

Het uitgangspunt voor deze studie is een aantal goed beredeneerde scenario's, met een keuze voor die variabelen die - voor zover nu bekend - de grootste impact zullen hebben en die onzeker zijn. Deze scenario's zullen vergeleken met een 'business as usual'- oftewel referentiescenario (zie ook sectie 0) waar deze variabelen ongewijzigd zijn.

\section{Handel}

Een eerste belangrijke variabele is de mate van vrijhandel. Landen zullen altijd blijven zoeken naar het optimaliseren van het wederzijds voordeel via handel. Nederland heeft als exportland ook altijd baat gehad bij een grote mate van vrijhandel en dat altijd internationaal in het algemeen bepleit. Daarom zijn varianten op de huidige situatie van belang. Er zijn een aantal factoren die vrijhandel kunnen gaan beperken. In de eerste plaats is dat het tanende multilateralisme dat ook de handelsbesprekingen in WTO-verband raakt. Ook komen bilaterale handelsverdragen minder gemakkelijk tot stand als daarin zaken op het gebied van duurzaamheid op mondiaal niveau niet goed zijn geregeld, met als gevolg bijvoorbeeld broeikasgasbelasting compenserende invoertarieven. In de tweede plaats heeft de corona-pandemie laten zien dat een mondiale waardeketen kwetsbaar is voor het wegvallen van schakels, zoals de aanvoer van een grondstof of de levering van een onderdeel of halffabricaat. Deze realisatie kan leiden tot meer aandacht voor zelfvoorziening, en versterkt de al bestaande tendens tot meer protectionisme. Hiermee samenhangend, is er een tendens van consumenten om, vanuit duurzaamheidsperspectief, meer de voorkeur te geven aan lokale producten.

Apart aandacht verdient de interne markt van de EU als vrijhandelsregio. Voor de land- en tuinbouw is de interne markt van zeer groot belang, omdat driekwart van de export daarheen gaat en die import voor $40 \%$ van binnen de EU komt. In onze aanpak van de scenario's laten we de interne markt ongemoeid en blijft de EU opereren als één handelsblok zonder interne tarieven.

\section{Vergroening: milieu/duurzaamheid}

Een tweede belangrijke variabele in de scenario's is de mate waarin duurzaamheidsinitiatieven actief zullen worden, in de EU en op mondiaal niveau. De EU lanceerde de Green Deal en werkte die voor de 
landbouw uit in de Farm to Fork Strategy (bijdrage landbouw aan klimaatbeleid: biobased materialen en bio-energie, forse toename percentage biologische landbouw). Ook de nieuwe Biodiversiteitsstrategie kan hierbij betrokken worden. Wat betekenen deze strategieën voor de landbouwproductie in Europa en in Nederland? De scenario's in deze studie zullen zich richten op de mate waarin druk op het milieu verminderd wordt door een $\mathrm{CO}_{2}$-tax, dieetverandering naar meer plantaardig eiwit, reductie van voedselverspilling, en meer grond voor natuur.

\section{B1.2.2 Opbouw van de scenario's}

De kerninzichten die we met de scenario's willen verkrijgen is de impact van de onzekerheden rondom vrijhandel en vergroening (duurzaamheid) voor de ontwikkeling van de Nederlandse landbouw. In onze scenario's focussen we op onzekerheden die op twee assen gedefinieerd kunnen worden, namelijk langs vrijhandel en vergroening (zie Figuur B1.). Voor de vergroenings-as wordt verondersteld dat de EU altijd verduurzaamt en de grootste onzekerheid is of de vergroeningsmaatregelen eenzijdig door de EU of wereldwijd worden geïmplementeerd. Vanwege de Europese Green Deal wordt in alle scenario's uitgegaan van vergaande vergroeningsmaatregelen in de EU (de details van de aannames rondom vergroening worden beschreven in 0 ). In de analyse zullen de resultaten van de nieuwe scenario's ten opzichte van een referentiescenario bekeken worden. Het referentiescenario, echter, houdt geen rekening met de implementatie van de Green Deal en de verduurzaming, handel en andere beleidsaannames worden op het huidige niveau gehouden.

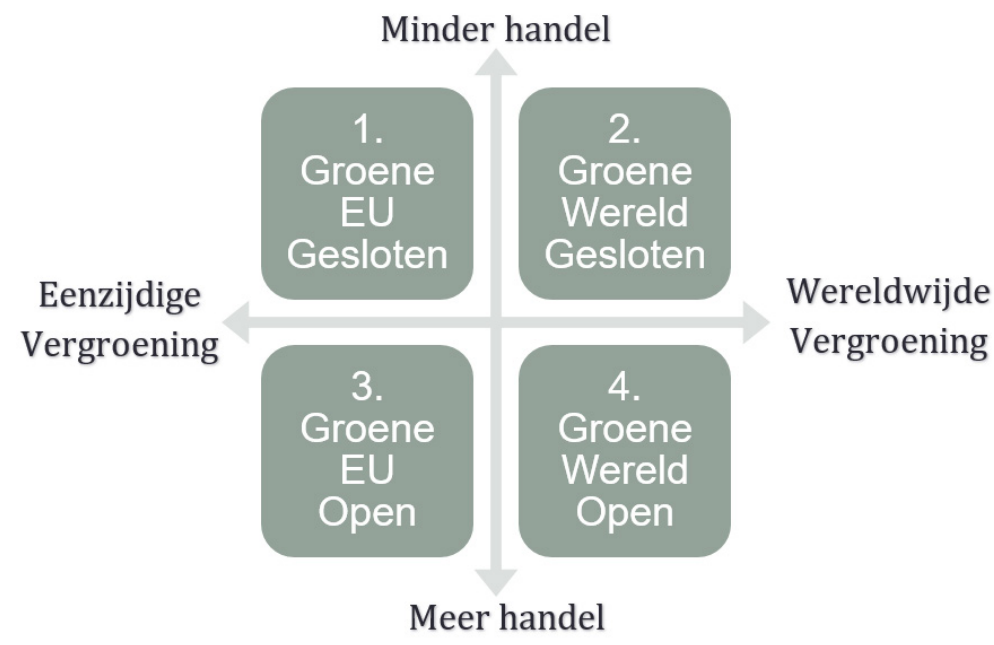

Figuur B1.1 Scenariomatrix

Gegeven de twee kernonzekerheden zien de vier vergroeningsscenario's er als volgt uit:

1. Groene EU Gesloten

Eenzijdige vergroening EU, minder vrijhandel tussen EU en de rest van de wereld vanwege invoertarieven die de broeikasgas-prijzen compenseren. Ook wordt een voorkeursverandering voor lokale producten (binnen EU) verondersteld.

2. Groene Wereld Gesloten

Wereldwijde vergroening, minder vrijhandel door verandering consumentenvoorkeuren. Voorkeur voor binnenlandse producten zowel in EU als andere regio's in de wereld.

\section{Groene EU Open}

Eenzijdige vergroening EU, vrijere internationale handel door graduele afschaffing van invoer- en exporttarieven.

\section{Groene Wereld Open}

Wereldwijde vergroening, vrijere internationale handel door graduele afschaffing van invoer- en exporttarieven. 


\section{B1.2.3 Referentiescenario 2050: Aannames en implementatie}

Een belangrijke basis voor het referentiescenario is de zogeheten Shared Socioeconomic Pathway 2 (SSP2) oftewel Middle of the Road-scenario van de IPCC community (SSP2, zie box B1.1).

\section{Box B1.1 Shared Socio-Economic Pathways}

The assumed GDP and population growth were based on the Shared Socioeconomic Pathway 2 (SSP2) scenario of the IPCC. The SSP scenarios define five possible paths that human societies could follow over the next century. The pathways are part of a cooperative research framework that is expected to improve the interdisciplinary analysis and assessment of climate change, its impacts, and the options societies have for mitigation and adaptation. The SSP2 is sometimes referred to as the Middle of the Road (or Dynamics as Usual, or Current Trends Continue, or Continuation, or Muddling Through) scenario. It is based on moderate GDP and population growth and is therefore considered a suitable baseline.

Technically, GDP will be exogenous only in a pre-simulation to determine the difficult to measure sectoral technical change. (O'Neill et al., 2017)

\section{Macro-economische en populatie aannames}

\section{Macro}

Het SSP2-scenario bepaalt het BBP, populatie en additionele aannames gewas productiviteitsgroei en voederconversie in het Referentiescenario (zie Figuur B1.). De additionele aannames zijn hetzelfde in alle scenario's.
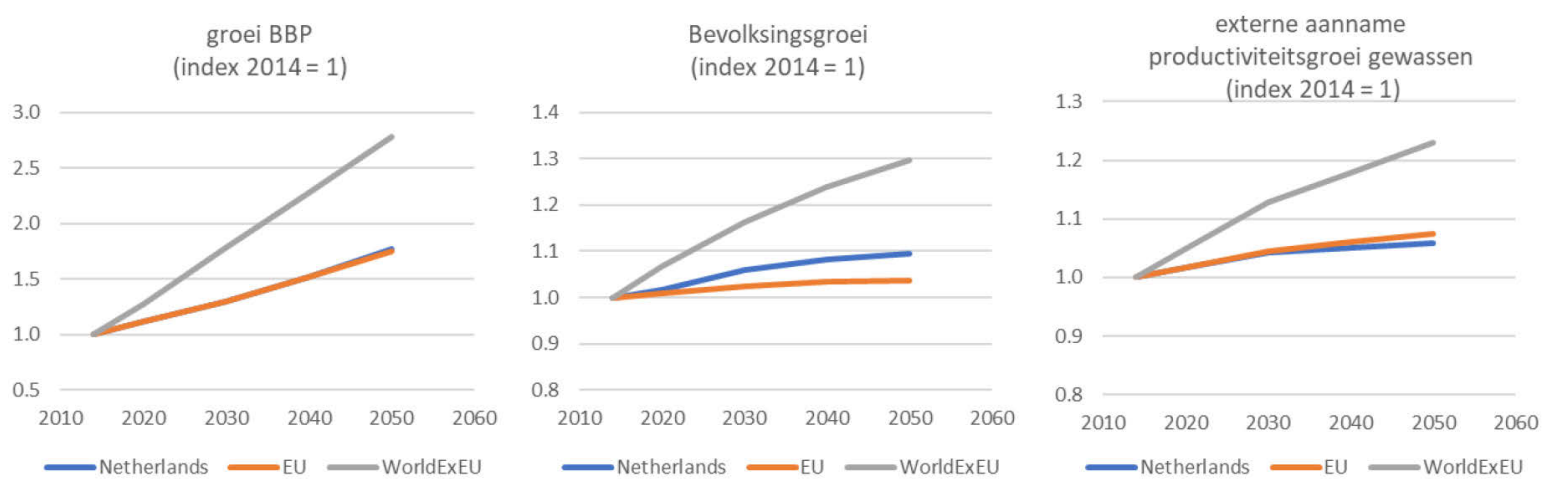

Figuur B1.2 BBP en populatie projecties op basis van SSP2 Bron: O'Neill et al. (2017).

Zoals te zien is in Figuur B1. geldt dat de aannames in SSP2 aangeven dat er in de rest van de wereld, met name ontwikkelingslanden, nog veel mogelijk is qua inkomensgroei, populatiegroei en gewasproductiviteit. Echter, regio's zoals Nederland en de EU zitten al dichter tegen het 'plafond' van wat technologisch haalbaar is wat betreft gewasproductiviteit. Naast deze onderzoeksgedreven externe aannames kan de gewasproductiviteit veranderen door managementveranderingen doordat bijvoorbeeld de relatieve prijs van grond versus andere productiefactoren verandert. Indien land duurder wordt, wordt land vervangen door arbeid of kapitaal en dit leidt ook tot een hogere gewasproductiviteit.

De SSP2 BBP-groei wordt gekalibreerd met parameters voor technische vooruitgang in het referentiescenario. Dat betekent dat het model de benodigde technologische ontwikkeling berekent om de SSP2 BBP-groei te halen. In de vier kernscenario's worden deze technische vooruitgangsparameters als model inputs verondersteld zodat het BBP-niveau een interne uitkomst wordt. De olieprijs volgt de trend van het 'IEA stated policy projection'-scenario, wat neerkomt op een stijging van $10 \%$ per periode van 10 jaar. Ook hier geldt dat deze prijs gekalibreerd wordt in het referentiescenario, maar wel nog kan veranderen in de vier andere scenario's. 
Een verdere aanname (of eigenlijk standaard modeloptie) is dat de relatieve werkloosheid op lange termijn gelijk gehouden wordt (conform natuurlijke werkloosheidcijfers, i.e. NAIRU). Dit houdt in dat in de scenario's de totale werkgelegenheid niet beïnvloed wordt door verschillende keuzes wat betreft verduurzaming. De verdeling van werkgelegenheid tussen sectoren is een uitkomst van het model en kan dus wel verschillen tussen de scenario's.

\section{Algemene beleidsaannames referentiescenario}

Uitgangspunt in referentiescenario is dat beleid wordt geïmplementeerd conform de huidige beleidsafspraken en constant wordt gehouden naar de toekomst. Dit betekent voor de EU dat het huidige (goedgekeurde) gemeenschappelijk landbouwbeleid (GLB) in het referentiescenario gehandhaafd wordt. Er wordt verschil gemaakt tussen eerste en tweede pijler van het GLB. Onder de eerste pijler, het EU-garantiefonds, vallen de inkomensondersteuning en het markt- en prijsbeleid. Onder de tweede pijler, het plattelandsfonds, valt het plattelandsontwikkelingsprogramma. Voor de toekomst worden subsidiepercentages gelijk gehouden evenals de verdeling tussen de eerste en tweede pijler.

Wat betreft handelsbeleid gelden de huidige handelsregelingen die tot uitdrukking komen in de invoeren exporttarieven zoals in GTAP 2014 database worden weergegeven. De tarieven worden procentueel gelijk gehouden naar de toekomst.

Biobrandstoffen en het beleid hieromtrent blijven op het huidige niveau en daarom wordt het percentage (aandeel) in brandstoffen constant gehouden voor zowel eerste als tweede generatie biobrandstoffen. Dit betekent dat het uitgangspunt is dat er geen verdere sterke groei van biobrandstoffen zal plaatsvinden zonder beleidsveranderingen.

Tabel B1.1 Aannames voor referentiescenario

\begin{tabular}{|c|c|c|}
\hline Onderdeel & & \\
\hline Handel & \multicolumn{2}{|c|}{ Import/export tarieven zoals GTAP (2014) } \\
\hline GLB & \multicolumn{2}{|c|}{ Onveranderd voor EU } \\
\hline Biobrandstoffen & \multicolumn{2}{|c|}{ Aandeel biobrandstoffen gelijk houdend na 2020} \\
\hline Hernieuwbare energie & \multicolumn{2}{|c|}{ Bestaand beleid. Aandeel van hernieuwbare elektriciteit als model uitkomst } \\
\hline $\mathrm{CO}_{2}$-eq-taks & \multicolumn{2}{|c|}{$\begin{array}{l}\mathrm{CO}_{2} \text {-eq-taks geïmplementeerd voor de EU op huidige prijzen ( } 25.15 \text { euro/ton, } \\
\text { peildatum } 20 \text { oktober 2020) en blijft constant vanaf } 2020 \text {. }\end{array}$} \\
\hline Biodiversiteit & $\begin{array}{l}\text { Huidig beschermd gebied, afname } \\
\text { landbouwareaal met 0,3\% per jaar } \\
\text { voor Nederland (Lesschen et al., } \\
2020 \text { ) }\end{array}$ & $\begin{array}{c}\text { Voor overige landen geldt dat het huidige } \\
\text { beschermd gebied is zoals wordt aangenomen in } \\
\text { SSP2 (WDPA database geïmplementeerd via } \\
\text { PBL/IMAGE) }\end{array}$ \\
\hline
\end{tabular}

\section{Aannames voor Nederland: milieuproductiequota en afname landbouwgrond}

Milieuproductiequota: Milieubeleid speelt een cruciale rol voor de toekomst van de Nederlandse agrifoodsectoren. Omdat we in deze studie niet specifiek op Nederlands milieubeleid focussen, en veel details van bijvoorbeeld het huidige mestbeleid niet expliciet in het MAGNET-model aanwezig zijn, wordt aangesloten bij studies die hier in detail naar hebben gekeken. We passen twee aannames toe op basis van het referentiescenario uit het rapport Scenariostudie perspectief voor ontwikkelrichtingen Nederlandse landbouw in 2050 (Lesschen et al., 2020). Het referentiescenario van Lesschen et al. (2020) gaat uit van bestaand beleid zonder additionele maatregelen, maar autonome ontwikkelingen in onder andere het landbouwareaal, dierlijke en gewasopbrengsten en voedselconsumptie. Het totale landbouwareaal is in 2050 afgenomen met ongeveer 200 duizend ha, als gevolg van autonome trends aan verlies landbouwgrond van ongeveer 0,3\% per jaar (zie Figuur B1.3). De afname van het areaal komt met name door externe ontwikkelingen voor de landbouw zoals agglomeratie, hernieuwbare energieteelten (zonnepanelen, houtachtig). De ontwikkeling van productievolumes van bepaalde gewassen (aardappelen, suikerbieten) zijn positief terwijl de dierlijke productie vrij stabiel is in het referentiescenario van Lesschen et al. (zie Figuur B1.4). Dit laatste komt doordat met name bestaand milieubeleid al beperkend is. 


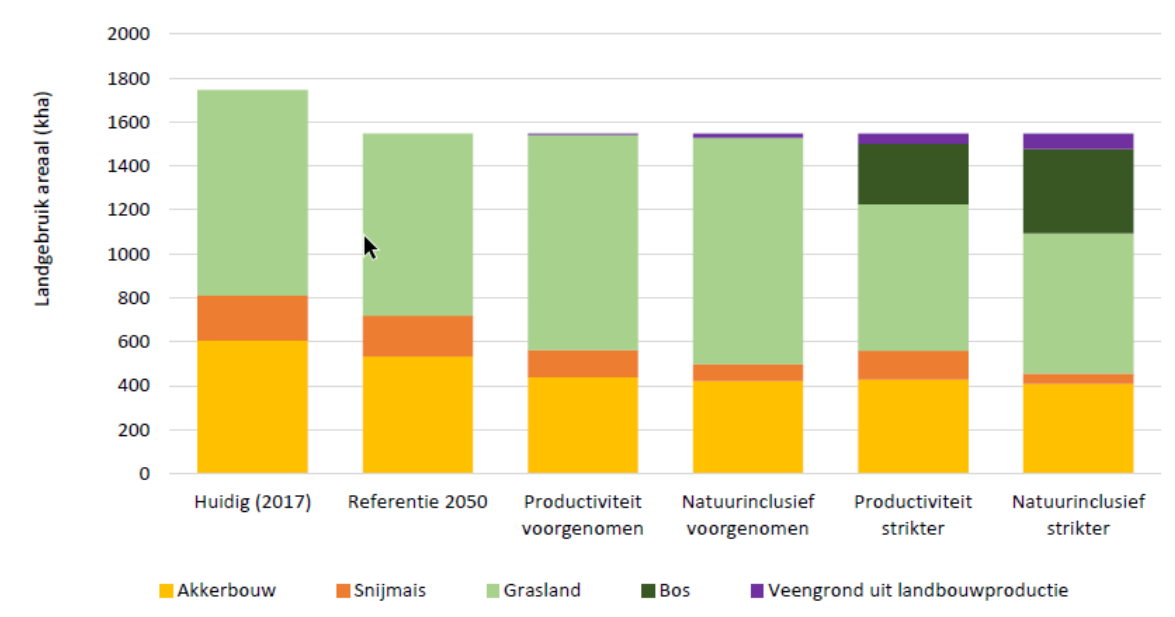

Figuur B1.3 Arealen landgebruik voor de scenario's in Lesschen et al. (2020)

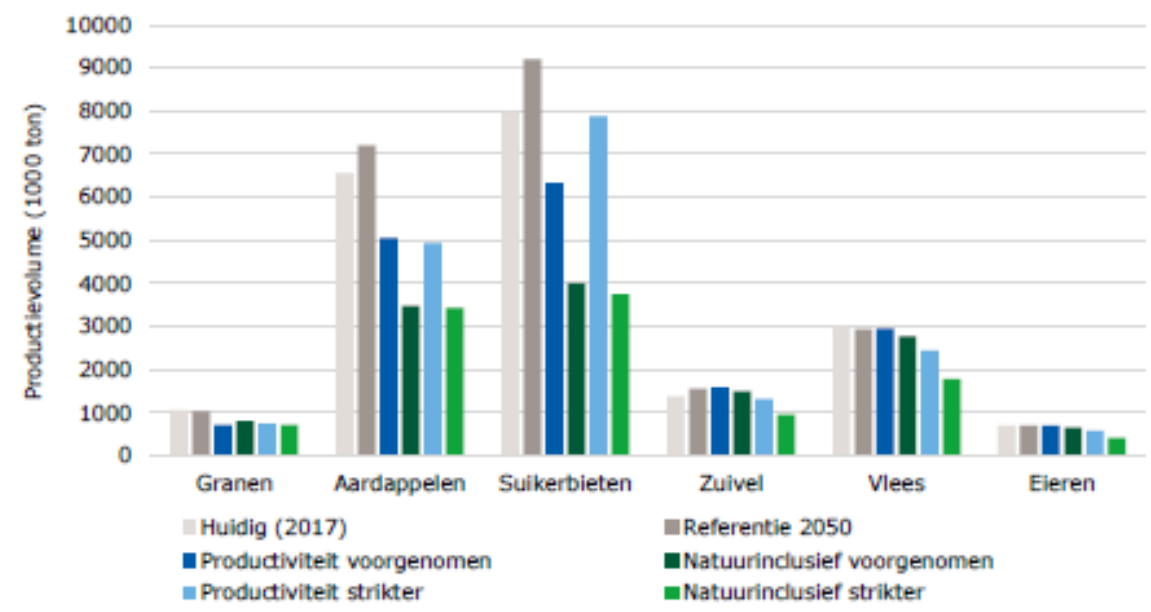

Figuur B1.4 Productievolumes voor de belangrijkste gewassen en dierlijke producten voor scenario's in Lesschen et al. (2020)

Het aantal dieren (zuivel, vlees, eieren) is dus stabiel of licht dalend (zie Figuur B1.4) in het referentiescenario van Lesschen et al. 2020. Ook voor de overige scenario's in Lesschen et al. 2020 wordt aangehouden dat er geen stijging van dierlijke productie zal plaatsvinden, maar wel een daling in de scenario's met strikter beleid. In het referentiescenario in onze studie veronderstellen we dat het aantal dieren zich ontwikkelt in lijn met het referentiescenario van Lesschen et al. 2020, waar de dierlijke productie stabiel blijft. Het kan gezien worden als een op bestaand milieubeleid gebaseerd 'milieu productiequota' voor de Nederlandse dierlijke sectoren. 


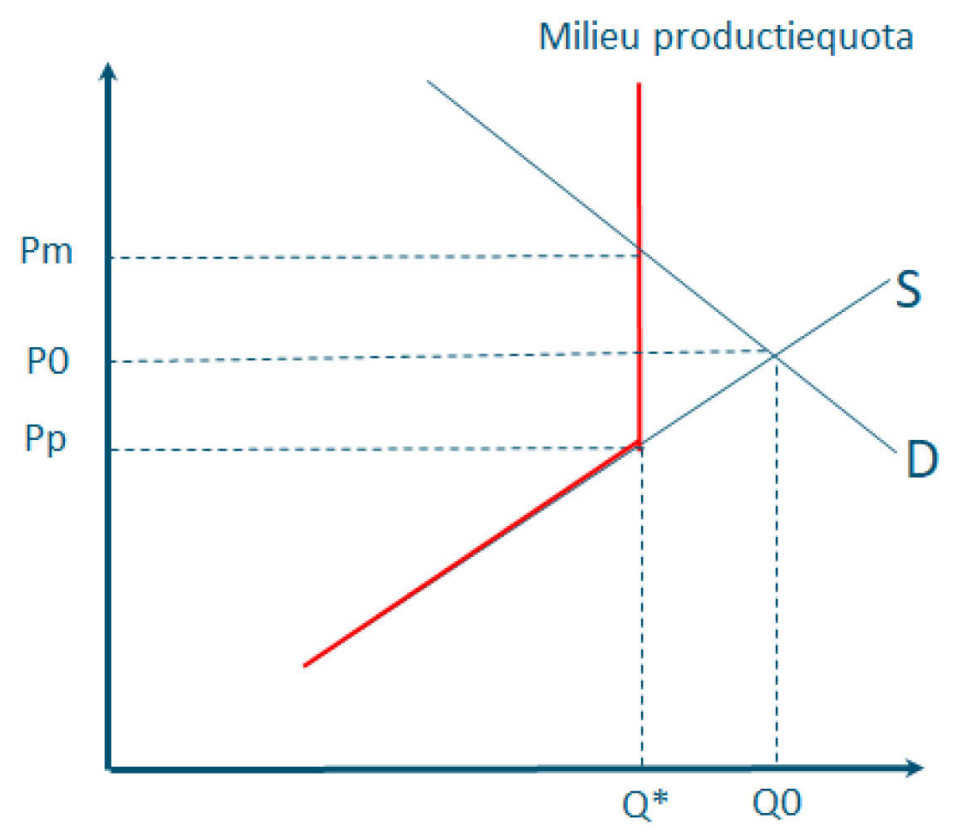

Figuur B1.5 Schematische weergave van een milieuproductiequotum, zoals in het referentiescenario gebruikt is

In het referentiescenario in deze studie veronderstellen we dus dat het bestaand milieubeleid impliceert dat het milieuproductiequotum bindend is, wat impliceert dat de dierlijke sectoren niet groeien in het referentiescenario. In het model is dit in het referentiescenario geïmplementeerd als een variabele belasting) die de dierlijke productie precies op huidig niveau houdt. Figuur B1.5 geeft de werking van een milieuproductiequotum weer. Zonder milieuproductiequota wordt de marktprijs (P0) en geproduceerde hoeveelheid (Q0) bepaald door vraag (D) en aanbod (S) in de markt. Een milieuproductiequotum ter grootte van $Q^{*}$ beperkt de productie tot $Q^{*}$ en de marktprijs stijgt naar Pm. Omdat productiekosten hier Pp zijn, ontstaat er een quota-rent (Pm-Pp maal $Q^{*}$ ) die naar ondernemers vloeit of via belastingen kan worden afgeroomd. Uit tussentijdse MAGNET-uitkomsten is het duidelijk dat zonder een dergelijk productiequotum op te leggen de dierlijke productie in Nederland sterk zou stijgen, iets wat dus onrealistisch is gezien het huidige milieubeleid en de milieuruimte die er is.

Samenvattend komt het aansluiten bij de bovenstaande studie op 1) het constant houden in het referentiescenario van de primaire productie van dierlijke sectoren op het niveau van 2014 (het startjaar van het model) door middel van een milieuproductiequotum en variabele belasting (quota rent) zoals hierboven beschreven, en 2 ) een afname van het totale landbouwareaal met 0,3\% per jaar wat in de scenario-opzet neerkomt op totaal -10,8\% over de periode $2014-2050$.

\section{B1.2.4 Vergroeningsscenario's: aannames en implementatie}

Hieronder zijn de elementen van de scenario's in meer detail beschreven. Hier gaat het om 'knoppen' die we nu hebben geïmplementeerd waarlangs de scenario's gespecificeerd worden.

\section{B1.2.4.1 Handel}

\section{Minder vrijhandel}

Voor de scenario's met gereduceerde handel gaan we uit van twee oorzaken. Ten eerste zal een eenzijdige vergroening in de EU mogelijk leiden tot compenserende importtarieven om de concurrentiekracht van de Europese producenten op peil te houden. Ten tweede gaan we in de 'minder handel'-scenario's uit van een verhoogde voorkeur voor lokale consumptie vanwege duurzaamheidsaspecten, voorkeur korte ketens, de alertheid op pandemieën, en algemeen tanend multilateralisme. 


\section{- Handel (Tarieven)}

Voor het scenario waarbij de EU eenzijdig vergroent (Groen EU, Gesloten), rekenen we met behulp van een referentie-scenario met $\mathrm{CO}_{2}$-eq-taks compenserende importtarieven (voor import naar EU als geheel). Dit komt conceptueel overeen met de 'complete Carbon Border Adjustment solution' zoals beschreven in een beleidsreview voor de Europese commissie. ${ }^{2}$

- Handel (Voorkeur)

Verder wordt in beide 'minder handel' varianten een preferentieverschuiving van 20\% naar meer lokaal (binnen EU in het geval van Europa) geïmplementeerd. De uitzondering voor de EU betekent dat de voorkeur voor producten uit verschillende lidstaten van de EU niet verandert (de gehele EU wordt gezien als een lokale markt). Figuur B1.6 geeft een schematische voorstelling van een $20 \%$ verschuiving in EU-handelsvoorkeur in 'Gesloten EU'-scenario. De voorkeur voor producten uit Europese Unie stijgt met $20 \%$ en die voor de rest van de wereld daalt met $20 \%$. Figuur B1.7 geeft een schematische voorstelling van verschuiving handelsvoorkeur in 'Gesloten Wereld'-scenario waar dit voor alle onderscheiden regio's geldt.

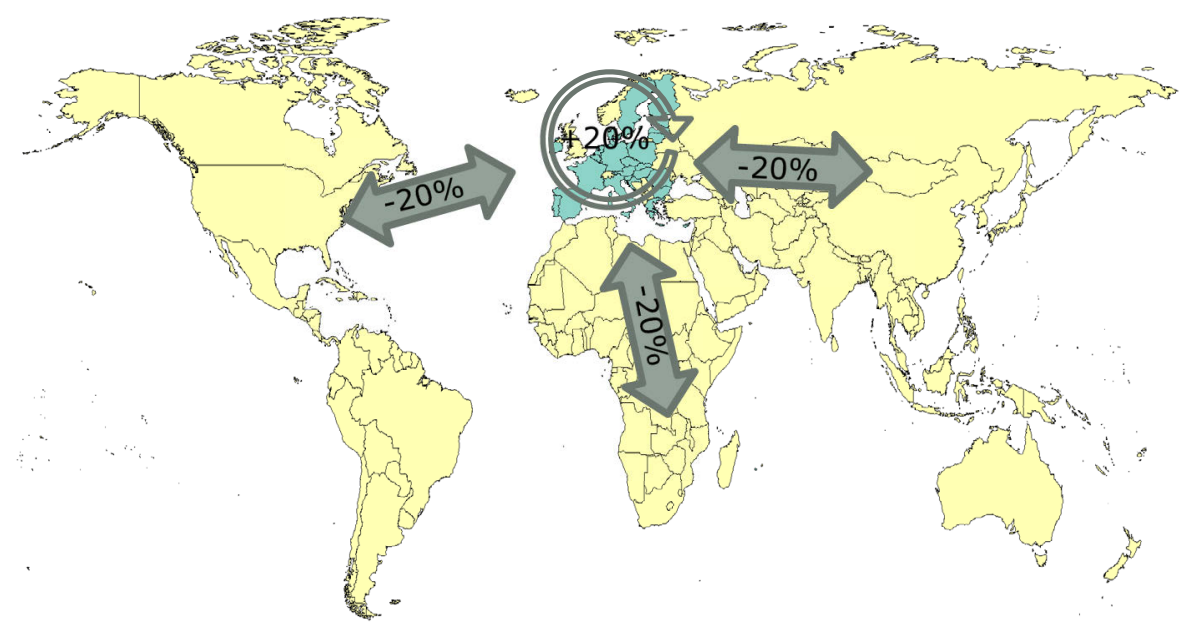

Figuur B1.6 Schematische voorstelling verschuiving in handelsvoorkeur in 'Gesloten EU'-scenario

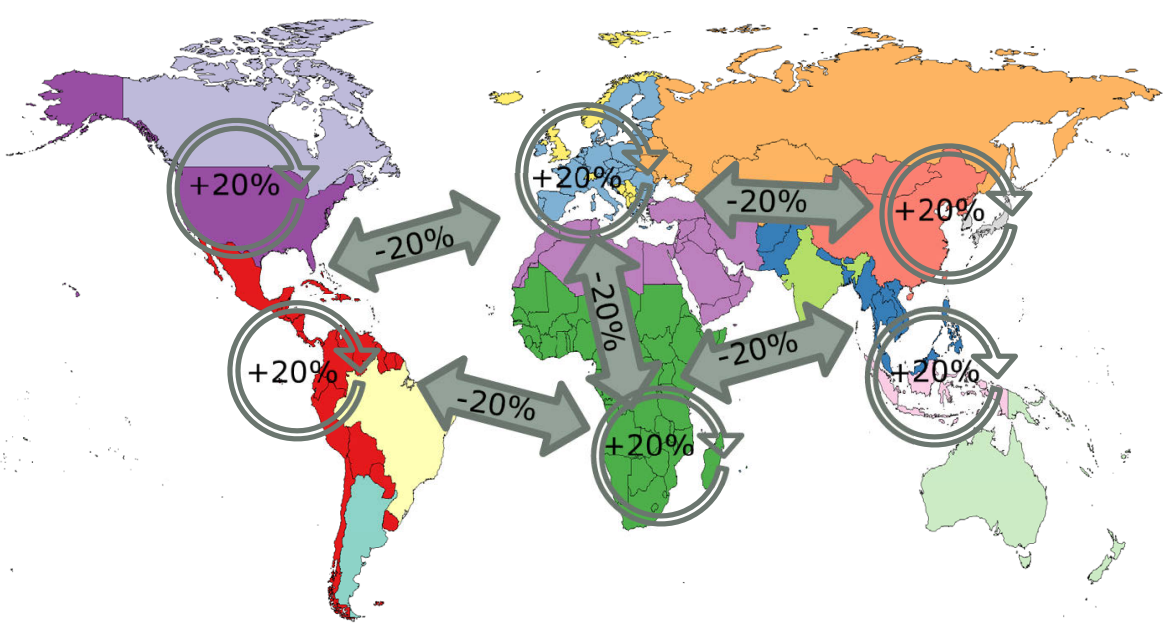

Figuur B1.7 Schematische voorstelling van verschuiving handelsvoorkeur in 'Gesloten Wereld'scenario

2 https://www.europarl.europa.eu/RegData/etudes/BRIE/2020/603500/EXPO_BRI(2020)603500_EN.pdf https://www.reuters.com/article/us-climate-change-eu-carbontax-explainer/explainer-what-an-eu-carbon-border-taxmight-look-like-and-who-would-be-hit-idUSKBN1YE1C4 


\section{Handel (Tarieven)}

In 'meer vrijhandel'-varianten worden import- en exporttarieven gradueel afgeschaft met $50 \%$ per periode van tien jaar vanaf 2020 (wat neerkomt op een $87,50 \%$ reductie van invoertarieven van het huidige niveau in 2050). De aannames rondom handelsvoorkeuren blijven hierbij ongewijzigd.

\section{B1.2.4.2 Vergroening}

Het doel is om de vergroeningsmaatregelen consistent te maken met een ' 2 graden en zo mogelijk 1,5 graden'-toekomst van het Parijsakkoord. De gradendoelstelling bepaalt het ambitieniveau en de te implementeren pakketten, maar we pretenderen niet een volledige kloppend 1,5-gradenscenario te implementeren. Belangrijk voor een wereldwijd scenario zijn de aannames over wat er buiten de EU gebeurt en dan ook met name binnen de sectoren energie en materialen. Ook speelt de discussie in welke mate de landbouw kan worden belast in verband met voedselzekerheid omdat mitigatiebeleid (bijvoorbeeld beprijzen van broeikasgassen) tot hogere voedselprijzen kan leiden (Hasegawa et al., 2018). In deze studie is het uitgangspunt dat Europa klimaatneutraal wordt door middel van de Green Deal en veronderstellen we dat de landbouw ook een stevige bijdrage dient te regelen. Uitkomsten van het model geven dan aan wat dit betekent voor de broeikasgasemissie, de voedselproductie en voedselzekerheid. Hoe Europa haar klimaatneutraliteit precies gaat bereiken is nog niet exact bekend, waarin vooral de verdeling tussen landen en sectoren nog een belangrijke onbekende is. Verder wordt hoe dan ook bij een eenzijdige implementatie in de EU (in de Groene EU-scenario's), zowel de 2 graden als 1,5 graden niet gehaald. Daarom zijn de keuzes die tot nu toe geïmplementeerd zijn vooral te zien als in lijn met een wereldwijde 1,5-gradenambitie, met een stevige bijdrage vanuit de landbouwsectoren, zonder te garanderen dat die doelstelling gehaald wordt.

Het modelleren van een volledig 1,5- of 2-gradenakkoord vergt veel aanvullende aannames over energie, transport en materialen sectoren en dan met name op energiebesparende technologieën en het beschikbaar komen van Carbon Capture and Storage (CCS). Deze modelopties vallen buiten de scope van het huidige project en daar zal niet specifiek naar gekeken worden; dit zou een andere exercitie zijn met veel focus op energie, transport en industrie sectoren om alles intern consistent voor een bepaald klimaatdoel te hebben.

Oftewel, om een nuttig scenarioraamwerk te hebben willen we aannames die aansluiten bij een ambitieus doel, en als kapstok daarvoor is dat nu voor de huidige set aannames ' 2 graden en zo mogelijk 1,5' graad. Er zijn meerdere combinaties van aannames die dat zouden kunnen bereiken. Het pad voor $\mathrm{CO}_{2}$-eq-taks (USD 205 per ton in 2050) is nu geijkt op een 2-gradenscenariopad van de GECO (Europese energie projecties van EC) 2018 (Philippidis et al., 2020)(Weitzel et al., 2019). Deze $\mathrm{CO}_{2}$-eq-taks is gangbaar in dit type scenariostudies, zoals bijvoorbeeld gebruikt in de meeste recente updates van de SSPs (IMAGE/TIMER) ${ }^{3}$ en het SUPREMA-project. ${ }^{4}$ Gaan we naar 1,5 graden op basis van met name $\mathrm{CO}_{2}$-eq-taks, dan kan deze oplopen tot wel 1.000 euro/ton $\mathrm{CO}_{2}$ in (zoals in GECO) en deze is sterk afhankelijk implementatie van onder andere CCS en andere technische opties. In een 1,5-gradenstudie van Rogelj et al. (2018) wordt bijvoorbeeld uitgegaan van USD 245 per ton in 2050 voor een 1,5-gradenstabilisatiescenario. Deze $\mathrm{CO}_{2}$-eq-taks is dicht bij de voorgestelde aanname van USD 205 per ton. Voor het aandeel hernieuwbare energie in de modelopzet doen we geen specifieke aanname vooraf, maar de uitkomst in vergroeningsscenario's is door de geïntroduceerde $\mathrm{CO}_{2}$-eq-taks nu 67\% hernieuwbaar elektrisch in Nederland en bijna 50\% in EU. Dit is in lijn met GECO 2018.

Verder kan voor de vergroeningsscenario's de tweede generatie biobrandstoffen wel endogeen groeien (hier speelt ook de $\mathrm{CO}_{2}$-eq-taks een belangrijke rol). Dit is in lijn met GECO 2018 en andere studies.

Veel van de aannames zijn gelijk getrokken over alle regio's (zoals bijvoorbeeld reductie van voedselverspilling), wat deels een praktische overweging is door gebrek aan eenvoudig toegankelijke gedetailleerde informatie (beleid of maatregelen te onzeker om verschillen tussen regio's te rechtvaardigen). Belangrijkste uitzondering is de trend van daling landbouwareaal/herbebossing, waar

\footnotetext{
3 Update van SSP-database, nog niet openbaar, persoonlijke communicatie Jonathan Doelman, PBL.

4 Rogelj, J., et al. (2018). Scenarios towards limiting global mean temperature increase below $1.5^{\circ} \mathrm{C}$. nature climate change, 8(4), 325-332. doi:10.1038/s41558-018-0091-3
} 
we enkel voor Nederland specifieke trends op basis van Lesschen et al. (2020) voorschrijven. Zie

Tabel B1.2 voor een overzicht van alle aannames.

\section{$\mathrm{CO}_{2}$-eq-taks}

Sturing efficiëntie en uitstoot beperkende maatregelen via $\mathrm{CO}_{2}$-eq-taks. Aanname $\mathrm{CO}_{2}$-prijs op basis van GECO 2018, wat volgens het 2-gradenpad neerkomt op USD 205/ton in 2050 (met in 2030 USD 50/ton, en in 2040 USD 125/ton) (Keramidas et al., 2018; Philippidis et al., 2020). Hierdoor worden in landbouw en veeteelt (maar ook kunstmestproductie) emissie efficiëntieverbetering door de $\mathrm{CO}_{2}$-prijs gestimuleerd. Dit kan enerzijds door substitutie van de nu duurdere vervuilende inputs in productie en vervuilende producten in consumptie. Input substitutie vindt in de landbouw plaats door bijvoorbeeld minder gebruik van op fossiel gebaseerde kunstmest bij gewassen of vervangen fossiele energie door groene energie in de glastuinbouw. Anderzijds kan er een emissiereductie potentieel geassocieerd worden met een gegeven $\mathrm{CO}_{2}$-prijs en deze relatie kan weergegeven worden door een MAC-curve. Voor een bepaald niveau van koolstofbelasting hebben producenten de keuze om ofwel hun uitstoot te verminderen door beschikbare reductiemaatregelen te nemen, ofwel dit niet te doen en een belasting te betalen op onverminderde uitstoot. De keuze voor (niet-)adoptie tegen een bepaalde $\mathrm{CO}_{2}$-prijs hangt af van de technische haalbaarheid/beschikbaarheid van reductiemaatregelen en de kosten van hun adoptie. De MAC-curve combineert externe informatie die expliciet verandering in emissieintensiteit en kosten van reductiemaatregelen voor de landbouw modelleert (Henderson et al., 2018). De kosten worden geïmplementeerd als een negatieve totale factor productiviteitsschok waardoor sectoren iets meer inputs nodig hebben om dezelfde output te genereren. Bij de veehouderij waar emissies (niet $\mathrm{CO}_{2}$-emissies) vaak samenhangen met het productieniveau zijn de reductiemaatregelen via een MAC curve van belang om de emissie intensiteit te verlagen. De MAC-curves zijn geïmplementeerd voor de $\mathrm{CH}_{4}$ - en $\mathrm{N}_{2} \mathrm{O}$-emissies in de agrisectoren.

\section{Voedselverspilling}

Het doel in Nederland is een halvering van de voedselverspilling in 2030 en dit is in lijn met de EU Green Deal en de SDG's. Als startpunt gaan we uit van een totaal van 33\% van voedselverlies (FAO, 2011) gelijk verdeeld over de drie stappen in de keten. Een Milieucentraal-rapport voor Nederland geeft percentage voedselverlies van $12 \%$ voor huishoudens, wat ongeveer in lijn hiermee is. ${ }^{5}$ Een halvering van voedselverspilling zou neer komen op circa $16,5 \%$ voedselverlies. Echter, in het PBLrapport Kwantificering van de effecten van verschillende maatregelen op de voetafdruk van de Nederlandse voedselconsumptie (Westhoek, 2019) wordt gerept over 5,3\% vermijdbaar afval bij consument, en $6 \%$ in transport/retail. Ook vanwege de manier van implementatie (gratis verbetering van efficiëntie in het MAGNET-model) is er gekozen om uit te gaan van een iets minder drastische variant die neerkomt op 33\% reductie in voedselverlies. Dit is ook in lijn met een zeer gangbare aanname in het SSP1-scenario (de 'duurzame' variant van de SSP2) en maakt deze keuze qua effect meer in orde van grootte van de andere aannames. Praktisch in het model betekent dit dat een $11 \%$ efficiëntieverbetering verdeeld wordt over productie, transport/services, en consumenten.

\section{Dieet}

De eiwitstrategie heeft een 60/40-doel voor plantaardig/dierlijk eiwitconsumptie, en dit komt voor Nederland grofweg overeen met een $-30 \%$ inzet voor consumptie dierlijke producten (te realiseren in 2050, van 63\% dierlijk eiwit naar $40 \%$ dierlijk eiwit, zoals ook is geformuleerd door de 'green protein alliance'). Dit komt overeen met een aanpak die standaard in SSP1 geïmplementeerd is. Dit is geïmplementeerd voor alle regio's, met uitzondering van ontwikkelingsregio's met intrinsiek lage vleesconsumptie (sub-Sahara Afrika, Indonesië, India, en Rest Zuid \& Zuidoost Azië).

\section{Afname landbouwgrond}

In het referentiescenario wordt voor Nederland afname van het landbouwareaal van 0,3\% per jaar door ontwikkelingen buiten de landbouw verondersteld op basis Lesschen et al. (2020). Voor Nederland wordt voor de vergroeningsscenario's uitgegaan van een verdubbeling van de ambities in 2050 van huidige akkoorden (bossenstrategie en klimaatakkoord, die tot 2030 lopen). Dit komt neer op 14.000 ha bos op landbouw (in bossenstrategie voor 2030 dus 7.000 ha) en 20.000 ha veen uit productie (in het klimaatakkoord is dat 10.000 ha omzetting naar natuurlijk). Dit is totaal een extra

5 https://www. milieucentraal.nl/media/mbrdwik5/syntheserapport-voedselverspilling-in-nederlandse-huishoudens-2019.pdf Ook op voedinscentrum ongeveer vergelijkbaar: https://www.voedingscentrum.nl/encyclopedie/voedselverspilling.aspx 
reductie van 34.000 ha in 2050. Inclusief de al geïmplementeerde daling voor de referentie komt dit neer op een daling van $0,351 \%$ per jaar, of totaal $12,64 \%$ minder in 2050 (ten opzichte van van $10,8 \%$ minder in baseline). Bij overige regio's in de wereld volgen we extra beschermde gebieden op basis van aannames uitgewerkt voor de SSP1 (Doelman et al., 2018; van Vuuren et al., 2017). Hierbij vindt geen extra herbebossing plaats, maar wel strikte bescherming van bestaand natuurgebied met als doel bescherming van $30 \%$ van het wereldwijde landoppervlak.

\section{Milieuproductiequota}

In het referentiescenario veronderstellen we een bepaalde ontwikkeling van de productie in de dierlijke sectoren op basis bestaand milieubeleid in lijn met Lesschen et al. (2020) en deze 'milieuruimte' is benaderd als een productiequota (inclusief variabele productie belasting/quota rent om productie op quota te houden, zie Figuur B1.5) voor de Nederlandse vleessectoren. Of deze restrictie op basis van bestaand beleid nodig is (i.e. of het milieu productiequota bindend wordt) is afhankelijk van de handelsen vergroeningsaannames in de vier scenario's. Door onder andere belasting van broeikasgassen en dieetverandering kan verwacht worden dat de vraag naar dierlijke producten afneemt. Indien het milieu productiequota bindend blijft zal de productie constant blijven en belasting/quota rent blijven bestaan al de hoogte hiervan dalen als de vraag afneemt. Dit wordt geïllustreerd in Figuur B1.8. De uitgangssituatie wordt gekenmerkt door een milieuproductiequota $\mathrm{Q}^{*}$ en de vraag (D) en aanbodcurve (S). In deze situatie is het milieuproductiequota bindend en de marktprijs is Pm en de quota rent (belasting) is Pm P**. Indien de vraag daalt door bijvoorbeeld dieetverandering of een belasting (e.g. vleestaks), verschuift de vraagcurve naar $D^{*}$. In deze situatie is het milieuproductiequotum nog steeds bindend en de verlaging van de vraag heeft niet geleid tot een productieafname maar is alleen de quota rent (belasting) verlaagd. Dit noemen we in deze studie het 'milieuproductiequota-effect'. Indien de vraag nog verder daalt, wordt het milieuproductiequotum niet meer bindend en zal ook de productie dalen. In Figuur B1.8 wordt dat weergegeven doordat vraag nu daalt naar $\mathrm{D}^{* *}$ en productie naar Q**, wat lager is dan het milieuproductiequota $\left(\mathrm{Q}^{*}\right)$. Indien de milieuruimte niet meer bindend wordt, kan de productie dalen en zal de belasting/quota rent nul zijn $\left(\mathrm{Pm}=\mathrm{p}^{* *}\right)$.

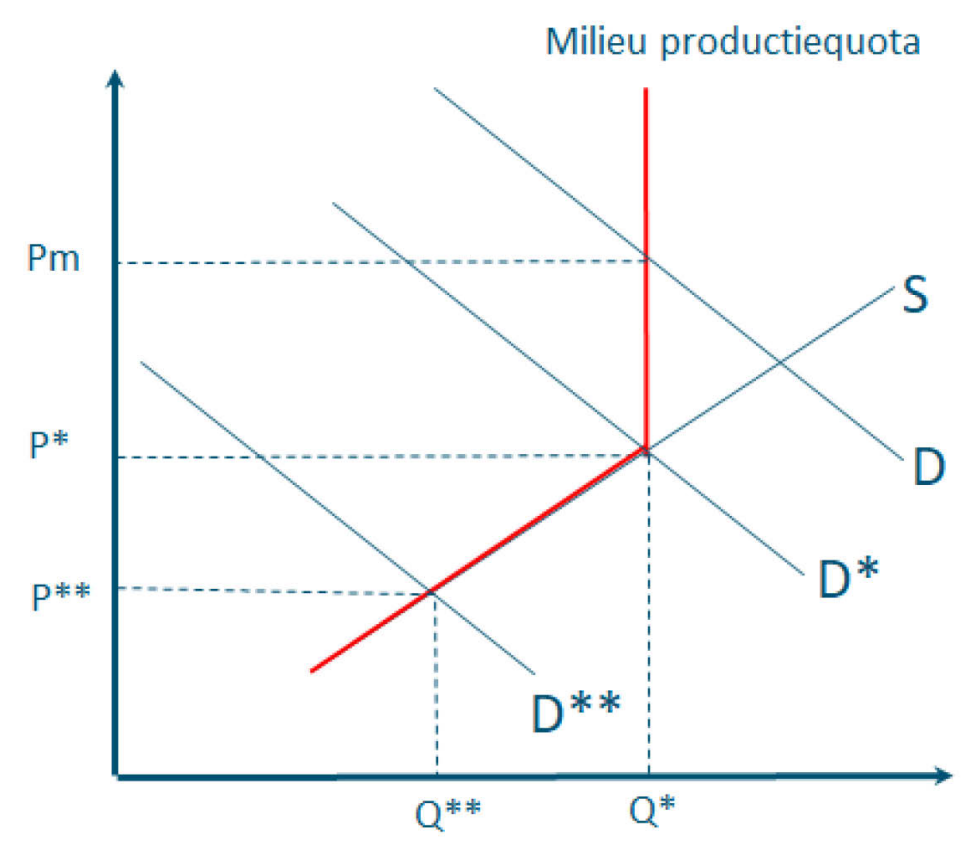

Figuur B1.8 Schematische weergave van een milieuproductiequotum en afnemende vraag, zoals in de vergroeningsscenario's het geval is 
Tabel B1.2 Overzicht aannames voor de vier scenario's

\begin{tabular}{|c|c|c|c|c|}
\hline & $\begin{array}{l}\text { 1. Groene EU } \\
\text { Gesloten: }\end{array}$ & $\begin{array}{l}\text { 2. Groene Wereld } \\
\text { Gesloten: }\end{array}$ & 3. Groene EU Open: & $\begin{array}{l}\text { 4. Groene Wereld } \\
\text { Open: }\end{array}$ \\
\hline & $\begin{array}{l}\text { Eenzijdige } \\
\text { verduurzaming EU, } \\
\text { minder vrijhandel }\end{array}$ & $\begin{array}{l}\text { Wereldwijde } \\
\text { verduurzaming, } \\
\text { minder vrijhandel }\end{array}$ & $\begin{array}{l}\text { Eenzijdige } \\
\text { verduurzaming EU, } \\
\text { meer vrijhandel }\end{array}$ & $\begin{array}{l}\text { Wereldwijde } \\
\text { verduurzaming, meer } \\
\text { vrijhandel }\end{array}$ \\
\hline $\begin{array}{l}\mathrm{CO}_{2} \text {-eq-taks } \\
\text { (Klimaatbeleid) }\end{array}$ & $\begin{array}{l}\text { EU CO}{ }_{2} \text {-eq-taks (USD } \\
205 / \text { ton in 2050) }\end{array}$ & $\begin{array}{l}\text { Wereldwijde } \mathrm{CO}_{2} \text {-eq- } \\
\text { taks (USD 205/ton in } \\
2050 \text { ) }\end{array}$ & $\begin{array}{l}\text { EU CO } \text { CO-eq-taks (USD } \text { 205/ton in 2050) }\end{array}$ & $\begin{array}{l}\text { Wereldwijde } \mathrm{CO}_{2} \text {-eq- } \\
\text { taks (USD 205/ton in } \\
2050 \text { ) }\end{array}$ \\
\hline Voedselverspilling & Reductie (33\%) in EU & $\begin{array}{l}\text { Reductie }(33 \%) \\
\text { wereldwijd }\end{array}$ & Reductie $(33 \%)$ in EU & $\begin{array}{l}\text { Reductie }(33 \%) \\
\text { wereldwijd }\end{array}$ \\
\hline Dieet & $\begin{array}{l}30 \% \text { minder vlees dan } \\
\text { in referentie scenario in } \\
\text { EU }\end{array}$ & $\begin{array}{l}30 \% \text { minder vlees dan } \\
\text { in referentiescenario } \\
\text { (wereldwijd exclusief } \\
\text { ontwikkelingslanden) }\end{array}$ & $\begin{array}{l}30 \% \text { minder vlees dan } \\
\text { in referentiescenario in } \\
\text { EU }\end{array}$ & $\begin{array}{l}30 \% \text { minder vlees dan } \\
\text { in referentie scenario } \\
\text { (wereldwijd exclusief } \\
\text { ontwikkelingslanden) }\end{array}$ \\
\hline Handel (Voorkeur) & $\begin{array}{l}20 \% \text { meer voorkeur } \\
\text { voor binnen EU } \\
\text { geproduceerde } \\
\text { producten in de EU }\end{array}$ & $\begin{array}{l}20 \% \text { meer voorkeur } \\
\text { voor producten in elke } \\
\text { regio }\end{array}$ & & - \\
\hline $\begin{array}{l}\text { Afname } \\
\text { landbouwgrond }\end{array}$ & $\begin{array}{l}\text { Extra bescherming land } \\
\text { zoals SSP1 voor EU }\end{array}$ & $\begin{array}{l}\text { Extra bescherming land } \\
\text { zoals SSP1 wereldwijd }\end{array}$ & $\begin{array}{l}\text { Extra bescherming land } \\
\text { zoals SSP1 voor EU }\end{array}$ & $\begin{array}{l}\text { Extra bescherming land } \\
\text { zoals SSP1 wereldwijd }\end{array}$ \\
\hline $\begin{array}{l}\text { Milieu } \\
\text { productiequota }\end{array}$ & $\begin{array}{l}\text { Voor NL } \\
\text { geïmplementeerd als } \\
\text { een productieplafond op } \\
\text { basis van Lesschen } \\
\text { et al. (2020). }\end{array}$ & $\begin{array}{l}\text { Voor NL } \\
\text { geïmplementeerd als } \\
\text { een productieplafond op } \\
\text { basis van Lesschen } \\
\text { et al. (2020) }\end{array}$ & $\begin{array}{l}\text { Voor NL } \\
\text { geïmplementeerd als } \\
\text { een productieplafond op } \\
\text { basis van Lesschen } \\
\text { et al. (2020) }\end{array}$ & $\begin{array}{l}\text { Voor NL } \\
\text { geïmplementeerd als } \\
\text { een productieplafond op } \\
\text { basis van Lesschen } \\
\text { et al. (2020) }\end{array}$ \\
\hline
\end{tabular}

\section{B1.2.5 Opzet MAGNET-model}

Voor de opzet van het MAGNET-model zijn een aantal keuzes te maken wat betreft onder andere tijdstappen en aggregatieniveau van regio's en sectoren. Deze zullen constant blijven bij de verschillende scenario's.

\section{Perioden}

De meest recente basisdata voor MAGNET (GTAP database) is 2014. De eerste periode zal voor 20142020 berekend worden en voor alle scenario's hetzelfde zijn. Daarna worden de periodes 2020-2030, 2030-2040, 2040-2050 uitgerekend, waar de externe aannames, en dus de uitkomsten, per scenario zullen gaan verschillen. Bij de presentatie van de resultaten zullen we met name focussen op de uitkomst in 2050 .

Er wordt in deze studie geen rekening gehouden met de impact van Covid-19, dus het resultaat voor 2020 kan niet vergeleken worden met de huidige situatie. De inschatting is dat de effecten op lange termijn zeer onzeker zijn. We nemen nu voor de scenario's aan dat een pandemie zich vooral zal uiten in afname van handelsmogelijkheden, zoals beschreven in de scenario-opzet.

\section{Regio's}

De opzet voor regio's is te zien in Figuur B1.9. West- en Oost-Europa worden onderscheiden en diverse belangrijke landen vanuit wereldexport of importperspectief (e.g. Argentinië, Brazilië, USA, China, India), waardoor we op een opsplitsing in 18 regio's uitkomen. 


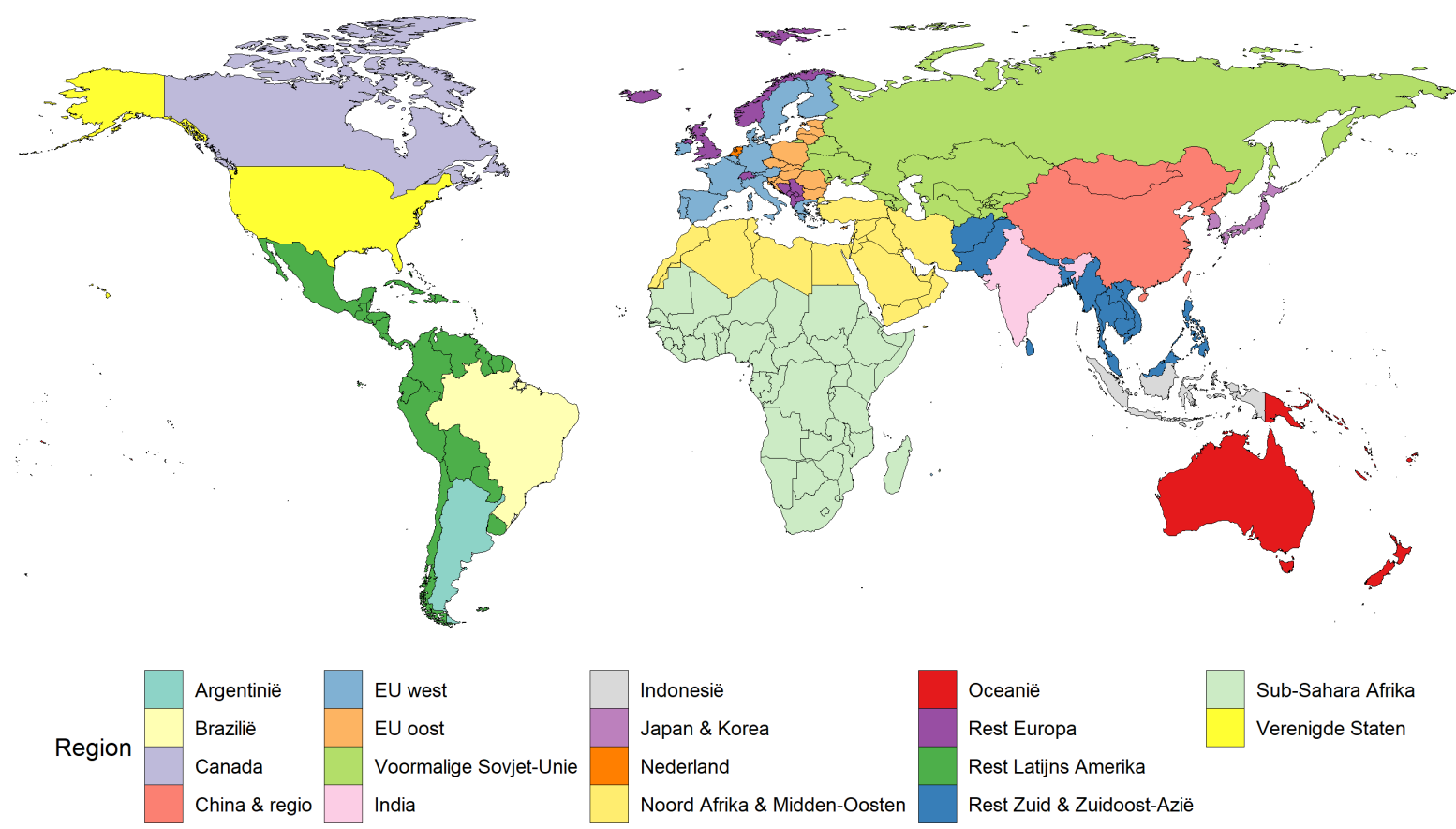

Figuur B1.9 Representatie van regio's in het MAGNET-model

\section{Sectoren}

In MAGNET (en het onderliggende GTAP) wordt algemeen uitgegaan van primaire sectoren en opvolgende verwerkende sectoren. Hieronder een overzicht en hoe dit verder geaggregeerd is voor de figuren om zaken eenvoudiger weer te geven. Het MAGNET-model, gebaseerd op het internationale handelsmodel GTAP, heeft meer detail voor de grondgebonden sectoren en intensieve veehouderij en minder voor de typische Nederlandse sectoren zoals sierteelt, bomen en bollen.

De hoofdresultaten zullen gepresenteerd worden voor drie hoofdaggregaties: Primair (plant), Primair (dier) en Verwerkt, en deze studie zal zich, in deze fase, niet verder in de onderliggende detail sectoren focussen, met uitzondering van een korte blik op de melkveehouderij en vleessector. Op dit niveau van drie hoofdaggregaties zijn de ontwikkelingen op hoofdlijnen te zien. Een gedetailleerder representatie vergt een update van de onderliggende data die buiten de scope deze studie valt.

Tabel B1.3 Overzicht van aanwezige agrifoodsectoren in het MAGNET-model

\begin{tabular}{|c|c|c|}
\hline & Primair & Verwerkte producten: a) \\
\hline \multirow[t]{5}{*}{ Planten } & Rijst & Verwerkte Rijst \\
\hline & Tarwe & \\
\hline & $\begin{array}{l}\text { Groente, fruit, noten, peulvruchten, aardappels, } \\
\text { wortels en knollen }\end{array}$ & \\
\hline & Vezelgewassen & \\
\hline & $\begin{array}{l}\text { Overige gewassen, zoals sierteelt, specerijen, rubber, } \\
\text { tabak, cacao. }\end{array}$ & \\
\hline \multirow[t]{2}{*}{ Dieren } & Rundvee (voor vlees) en paarden & Rund \& paardenvlees \\
\hline & Wol & \\
\hline \multirow[t]{2}{*}{ Vis } & Visserij & Verwerkte vis of vismeel \\
\hline & Aquacultuur & \\
\hline
\end{tabular}

a) Naast de 'other food' voedselverwerkende sector waar veel producten uit primair worden verwerkt en diervoeder die verschillende primaire sectoren als input heeft. 
Elke dierlijke productie heeft een directe verwerkende sector, zoals zuivel in het geval van melk, rundvlees in het geval van rundvee. Voor het plantaardige systeem zijn er de verwerkte rijst, suiker en melasse uit suikergewassen, en plantaardige olie uit oliegewassen. Hiernaast is er nog een grote 'overig voedsel' sector waarin alle overige verwerkte producten zitten. Deze kan zowel plantaardige producten als vlees bevatten.

\section{B1.3 Resultaten scenario's}

\section{B1.3.1 Observaties voor referentiescenario en de 4 vergroeningsscenario's}

In deze sectie worden de resultaten kort per scenario beschreven, met een focus op Nederland. Het referentiescenario wordt iets uitgebreider beschreven omdat het de basis voor de overige scenario's vormt. De overzichtstabellen in de bijlage (onderdeel Bijlage 2, Tabel B1.10 tot Tabel B1.13) geven in meer detail de achterliggende cijfers voor de verschillende variabelen.

\section{B1.3.1.1 Referentiescenario-observaties}

De primaire dierlijke productie in Nederland blijft constant in de periode tot 2050; dit is op basis van Lesschen et al. (2020) geïmplementeerd als een milieu productiequota. Wereldwijd stijgt de dierlijke productie echter met $40 \%$ vanwege een sterk groeiende vraag door bevolkingsgroei en welvaart. In de rest van de EU stijgt de dierlijke productie wel nog met zo'n $10 \%$. Zonder de implementatie van het milieuproductiequotum zou de dierlijke productie in Nederland met bijna $20 \%$ zijn gestegen. Wereldwijd stijgt de totale primaire productie met 30\% terwijl het grondgebruik met circa $10 \%$ een stuk minder stijgt, wat wijst op de bijdrage van, en noodzaak tot, efficiëntere en intensievere productie. In Nederland daalt het agrarisch grondgebruik met 0,3\% per jaar, wat volledig verklaard wordt door aannames over externe ontwikkelingen en niet door ontwikkelingen binnen de landbouw.

In het referentiescenario dalen de reële prijzen voor agrifoodproducten verder conform de lange termijn trend. Dit duidt erop dat productiviteitsstijgingen nog altijd hoger zijn dan de toegenomen vraag. In het algemeen zijn productiviteitsstijgingen in de agrifoodsectoren hoger dan voor het gemiddelde van de economie, wat mede komt doordat productiviteitsstijgingen in veel dienstensectoren beperkt zijn (een kapper heeft nog steeds ongeveer evenveel tijd nodig om iemand te knippen dan 30 jaar geleden) en anderzijds wordt de landbouw gekenmerkt door een vrij inelastische vraag. Dit houdt in dat indien we meer gaan verdienen, we niet veel meer gaan eten boven een bepaald inkomensniveau (wat zeker het geval zal zijn in 2050). Deze daling treedt dan ook met name op bij primair plant en wat minder bij primair dier en verwerkte producten waar inkomenselasticiteiten nog wat hoger zijn.

In Nederland vertalen deze trends zich vooral in een hogere productie van de verwerkte industrie voor de export, mede mogelijk gemaakt door verhoogde import van primaire producten. Door het milieuproductiequotum is productie in primaire sectoren redelijk stabiel. Waar de toegevoegde waarde van de primaire sectoren dalen (gelijke productie en dalende reële prijzen), stijgt die van de voedselverwerkende industrie met $40 \%$. Het belang van de verwerkende industrie neemt dus fors toe in het referentiescenario. De gesegmenteerde factormarkten voor land, arbeid en kapitaal tussen landbouw- en niet-landbouwsectoren (zie sectie 1.4) spelen hier ook een rol omdat in het referentiescenario de factor beloningen in de primaire landbouw achterblijven bij de rest van de economie (waartoe ook de verwerkende industrie behoort). Door de gesegmenteerde factormarkten accepteren werknemers in de agrarische sectoren een lager loon indien het relatief slechter gaat in deze sectoren ten opzichte van de rest van de economie, omdat ze niet de kennis en kunde hebben om direct in andere sectoren met een hoger loon te gaan werken. In het Referentiescenario stijgen de beloningen voor arbeid in de rest van de economie met ongeveer 50\%-62\% terwijl deze in de landbouw met 5\%-12\% stijgen (zie Tabel B1.4). De vraag naar land blijft relatief hoog zodat de grondprijzen met $25 \%$ stijgen. 
Tabel B1.4 Prijzen productiefactor Nederland in referentiescenario (relatieve waarde in 2050, en \% verandering 2014-2050)

\begin{tabular}{llll} 
Productie & Primair & Verwerkt & Totaal economie \\
Land & $1,25(25 \%)$ & $0(0 \%)$ & $1,26(26 \%)$ \\
\hline Ongeschoolde Arbeid & $1,05(5 \%)$ & $1,50(50 \%)$ & $1,48(48 \%)$ \\
\hline Geschoolde Arbeid & $1,12(12 \%)$ & $1,63(62 \%)$ & $1,61(61 \%)$ \\
\hline Kapitaal & $0,68(-32 \%)$ & $1,09(9 \%)$ & $1,09(9 \%)$ \\
\hline Totaal & $0,94(-6 \%)$ & $1,14(14 \%)$ & $1,17(17 \%)$ \\
\hline
\end{tabular}

Vanwege autonome verbeteringen in efficiëntie van broeikasgas gerelateerde inputs dalen de emissies van landbouw in Nederland van 26,2 naar 23,5 $\mathrm{Mt} \mathrm{CO}_{2}$-eq. In het referentiescenario dalen emissies alleen door efficiënter energie- en inputgebruik, terwijl anders dan in de overige scenario's, er geen verbetering in emissie-intensiteit van bijvoorbeeld methaanuitstoot op de boerderij plaatsvindt. Dit laatste komt onder andere omdat de methaanemissie samenhangt met de productieomvang bij dieren en doordat de $\mathrm{CO}_{2}$-prijzen in het referentiescenario niet verder stijgen en daardoor geen extra druk geven om emissie-intensiteit te verlagen. In de EU daalt de landbouwemissie slechts zeer licht, aangezien daar de primaire productie, inclusief de productie van dieren, nog wel stijgt. Wereldwijd stijgen emissies van landbouw gemiddeld met bijna $40 \%$, veroorzaakt door de sterke stijging van de dierlijke productie.

\section{B1.3.2 Groene EU Gesloten: EU vergroent eenzijdig en beschermt de interne markt}

Dit scenario ('Groene EU Gesloten') wordt gekenmerkt door vergroening in de EU door een $\mathrm{CO}_{2}$-eqtaks, reductie voedselverspilling, dieetverandering en extra agrarisch land dat uit productie wordt genomen (onder andere biodiversiteitsbescherming). Aan de handelskant wordt een bescherming van de interne markt geïntroduceerd door $\mathrm{CO}_{2}$-eq-taks compenserende invoertarieven. Ten slotte verschuift de voorkeur voor producten binnen de $\mathrm{EU}+20 \%$ ten koste van invoer uit de rest van de wereld.

De productie van primair dierlijk daalt in Nederland met maar $6 \%$ en de daling wordt veroorzaakt door met name de $\mathrm{CO}_{2}$-eq-taks $(-16 \%)$ en de dieetverandering $(-17 \%)$. Deze daling wordt beperkt door de compenserende invoertarieven ( $9 \%)$, reductie van voedselverspilling (7\%) en met name de macroeconomische effecten (17\%). In totaal daalt de dierlijke productie met $6 \%$ in Nederland waaruit blijkt dat het milieuproductiequota op basis bestaand beleid niet meer bindend is voor de dierlijke sectoren (zie Figuur B1.8). De productie van gewassen stijgt met 7\% door met name de dieetverandering (6\%), de voorkeur voor interne EU-producten (3\%) en de compenserende tarieven aan de EU-grens (4\%). De afname van landbouwgrond doet de primaire gewas productie dalen met $6 \%$.

Compenserende tarieven spelen een belangrijke rol in het op peil houden van de productie in zowel Nederland als de EU. Dit geldt met name voor de dierlijke productie. De productie van verwerkte producten stijgt met $11 \%$ ten opzichte van de referentie uitkomst in 2050 (totale stijging $28 \%$ ) door met name de reductie van voedselverspilling (11\%) waardoor deze export-georiënteerde sectoren een concurrentievoordeel verkrijgen ten opzichte van buitenlandse sectoren. De eenzijdige efficiëntieslag door verlaging van voedselverspilling maakt met name de Nederlandse en Europese voedselverwerkende industrie competitiever. Door deze efficiëntieslag en doordat in de rest van de wereld het consumptieniveau (van dierlijke producten) hoog blijft stijgt de Nederlandse productie en export ten opzichte van het referentiescenario voor de voedselverwerkende industrie. Dit komt bovenop de stijging van de export in het referentiescenario. De export van de primaire sector stijgt in totaal met $8 \%$ ten opzichte van de referentie-uitkomst. Hierin schuilt echter een sterke stijging binnen de $\mathrm{EU}$, en een daling voor export naar buiten de EU. Met name door de $\mathrm{CO}_{2}$-eq-taks compenserende tarieven stijgen exporten en dalen importen tussen Nederland en de rest van de wereld.

De emissies van de Nederlandse dierlijke productie dalen met 30\% ten opzichte van de referentie. Deze daling is minder sterk dan in andere scenario's door het beschermende effect van de compenserende invoertarieven. Op wereldschaal heeft dit scenario dan beperkt effect. De daling van emissies gerelateerd aan primair plant is slechts $1 \%$ en voor primair dier is de daling $3 \%$ ten opzichte van de referentie uitkomst in 2050 . 


\section{B1.3.3 Groene Wereld Gesloten: De wereld doet mee (met vergroening), maar met tanend multilateralisme/minder handel}

Dit scenario ('Groene Wereld Gesloten') wordt gekenmerkt door vergroening wereldwijd door een $\mathrm{CO}_{2}$ eq-taks, reductie voedselverspilling dieetverandering en extra land voor de biodiversiteitsbescherming. Verder verschuift de voorkeur naar producten uit eigen regio met $+20 \%$ ten koste van import uit de rest van de wereld.

In dit scenario daalt de dierlijke productie in Nederland met $22 \%$ en dat is veel sterker dan in het Groene EU Gesloten-scenario. Ten opzichte van dat scenario komt dit door de wereldwijde verlaging van vleesconsumptie (Dieet, $-21 \%$ ) en doordat het concurrentievoordeel dat door de reductie van voedselverspilling niet meer aanwezig is aangezien alle wereldregio's hier nu meer efficiëntie behalen. Het voedselverspillingseffect is zelfs negatief $(-4 \%)$ doordat de totale vraag naar vlees hierdoor afneemt. Het negatieve effect van de $\mathrm{CO}_{2}$-eq-taks $(-7 \%)$ is daartegenover minder negatief omdat alle landen dezelfde $\mathrm{CO}_{2}$-eq-taks geïmplementeerd hebben. De groei van de plantaardige productie in Nederland is $6 \%$ ten opzichte van referentie in 2050 , slechts iets lager dan in het Groene EU Geslotenscenario. De belangrijkste factor $(-10 \%)$ hiervoor is de verlaging van wereldwijde voedselverspilling wat de vraag beperkt. Dit laatste wordt deels gecompenseerd door voorkeur voor producten uit de EU (9\%). Omdat de EU veel gewassen importeert is dit effect aanzienlijk. In dit scenario is ook de productie van de voedselverwerkende industrie in Nederland $2 \%$ lager dan de referentie-uitkomst in 2050. Het behaalde concurrentievoordeel doordat alleen de EU voedselverspilling reduceert treedt in dit scenario niet op omdat dit wereldwijd gebeurt.

Er is een sterke daling van handel (zowel import als export) met de regio's buiten de EU voor alle hoofdsectoren, met een duidelijk effect op het BBP. Door productie en prijsdalingen daalt in dit Groene Wereld Gesloten-scenario de toegevoegde waarde van de primaire sectoren met 3\%, contrasterend met een lichte stijging van $+1 \%$ in het Groene EU Gesloten-scenario. De toegevoegde waarde daalt nu ook voor de verwerkte producten ten opzichte van het referentiescenario. De sterke daling van primaire dierlijke sectoren en de veel beperktere stijging exporten zijn hier mede debet aan.

De emissies van dierlijke productie dalen met 43\% in Nederland en 6\% tussen 2014 en 2050, dit is een substantieel sterkere daling dan wanneer de EU eenzijdig vergroent (respectievelijk een daling van $34 \%$ in Nederland, maar een wereldwijde stijging van 54\%). Hier is duidelijk de sterke invloed aanwezig van de wereldwijde stijging van dierlijke productie vanwege macrotrends, waardoor zelfs bij de wereldwijde vergroeningsscenario's de dierlijke productie nog steeds licht stijgt.

\section{B1.3.1.4 Groene EU Open: EU vergroent eenzijdig met vrije handel/afschaffing tarieven.} Het Groene EU Open-scenario wordt gekenmerkt door vergroening eenzijdig in de $\mathrm{EU}$ door $\mathrm{CO}_{2}$-eqtaks, reductie voedselverspilling, dieetverandering en extra biodiversiteitsbescherming. Daarnaast een graduele afschaffing van importtarieven en exportsubsidies tussen EU en de rest van de wereld. Er is geen verschuiving in voorkeur naar lokale producten.

De Nederlandse productie daalt sterk in de dierlijke sector $(-18 \%)$, maar plantaardig $(1 \%)$ en verwerkt $(5 \%)$ laten nog steeds een kleine stijging zien ten opzichte van het referentiescenario. Dit komt onder andere doordat in de rest van de wereld de vraag nog op peil blijft omdat vergroening daar nog uitblijft. De daling in de dierlijke sectoren is 3 maal sterker dan in Groene EU Geslotenscenario. De invloed van de $\mathrm{CO}_{2}$-eq-taks $(-18 \%)$ en dieetverandering $(-16 \%)$ is nog steeds negatief, maar door het ontbreken van compenserende invoertarieven en het afschaffen van beschermende tarieven (-5\%; invoertarieven zijn relatief hoog in de EU ten opzichte van andere regio's) worden deze niet gecompenseerd.

De Nederlandse export en import stijgen door het wegvallen van tarieven/subsidies en doordat $\mathrm{CO}_{2}$ eq-taks niet gecompenseerd wordt via de invoertarieven. In Nederland heeft dit vooral als effect een verhoging van de import van dierlijke producten, waar internationale concurrentie sterk toeneemt door afbouw van de invoertarieven op verwerkte dierlijke producten en relatief hoge $\mathrm{CO}_{2}$-eq-taks. Daarom stijgt ook door afschaffing van de invoertarieven de import door de verwerkende sector (met name in dierlijke producten) en importeert Nederland meer verwerkte producten (met name verwerkt vlees). 
De emissies van dierlijke productie dalen met $40 \%$ ten opzichte van de referentie-uitkomst in Nederland en met $44 \%$ in totaal. De totale landbouwemissies dalen met $33 \%$ in Nederland ten opzichte van het referentiescenario in 2050. Op wereldniveau resteert slechts een vrij klein effect, met slechts $-1 \%$ daling van emissies ten opzichte van de referentie-uitkomst in 2050.

\section{B1.3.1.5 Groene Wereld Open: De wereld vergroent en liberaliseert.}

Het Groene Wereld Open-scenario wordt gekenmerkt door wereldwijde vergroening door middel van een $\mathrm{CO}_{2}$-eq-taks, reductie voedselverspilling, dieetverandering en extra biodiversiteitsbescherming. Verder is er een graduele afschaffing van importtarieven en exportsubsidies tussen alle regio's en is er geen voorkeurshift naar lokale producten.

Dit is het scenario waarin de agrarische productie in Nederland het meest daalt. Algehele productie en vraag daalt door verlaging voedselverliezen, $\mathrm{CO}_{2}$-eq-taks, verminderde dierlijke consumptie door dieetverandering, en door handelsliberalisatie. Dierlijke productie daalt met $23 \%$, terwijl plantaardig en verwerkt met respectievelijk $2 \%$ en $5 \%$ dalen ten opzichte van de referentie-uitkomst in 2050 . Het afschaffen van tarieven treft de dierlijke sectoren $(-5 \%)$ en voedselverwerkende industrie $(-3 \%)$ ten opzichte van de 'gesloten handel'-scenario's. De wereldwijde reductie van voedselverspilling treft met name de voedselverwerkende industrie en primaire gewassen doordat de wereldwijde vraag vermindert en de EU geen concurrentievoordeel krijgt ten opzichte van andere regio's omdat deze ook hun voedselverspilling beperken.

Daartegenover staat dat dit voor Nederland een scenario is waar het gevolg voor het BBP zelfs licht positief is met een groei van $+0,4 \%$ en opzicht van de referentie in 2050 . Dit ondanks het negatieve $\mathrm{CO}_{2}$-eq-taks effect $(-1 \%)$. Vrijhandel $(0,6 \%)$ en reductie voedselverspilling $(0,7 \%)$ leiden tot een gunstig BBP-effect bij een dalende Nederlandse agroproductie.

De daling van broeikasgasemissies is het hoogst van alle scenario's. De emissies van dierlijke productie dalen met $-42 \%$ in Nederland en $-49 \%$ wereldwijd ten opzichte van referentiescenario in 2050. Voor gewassen is dat $-16 \%$ in Nederland en $-26 \%$ wereldwijd (significante reductie methaan emissies van rijst, wat in Nederland niet zo speelt).

\section{B1.3.2 Productievolume}

Figuur B1.10 toont primaire productievolumes voor 2014 en voor 2050 voor de scenario-uitkomsten, voor Nederland, EU, en Wereldwijd. Duidelijk is de sterke daling van dierlijke productie bij alle vergroeningsscenario's. In het Groene EU Gesloten-scenario wordt deze daling enigszins beperkt door compenserende invoertarieven en de reductie van voedselverspilling. De plantaardige productie stijgt in Nederland, behalve in het Groene Wereld Open-scenario. Op wereldniveau krijgen we alleen substantiële effecten wanneer de vergroening wereldwijd wordt ingezet. De vergroening leidt dan tot een substantiële reductie van dierlijke productie en een beperkte daling van plantaardige productie. De daling komt onder andere door reductie voedselverspilling en door beprijzing broeikasgasemissies. Tezamen met de dieetverandering zorgt dit voor behoorlijke afname dierlijke productie. De dieetverandering heeft ceteris paribus een positief effect op de plantaardige productie.
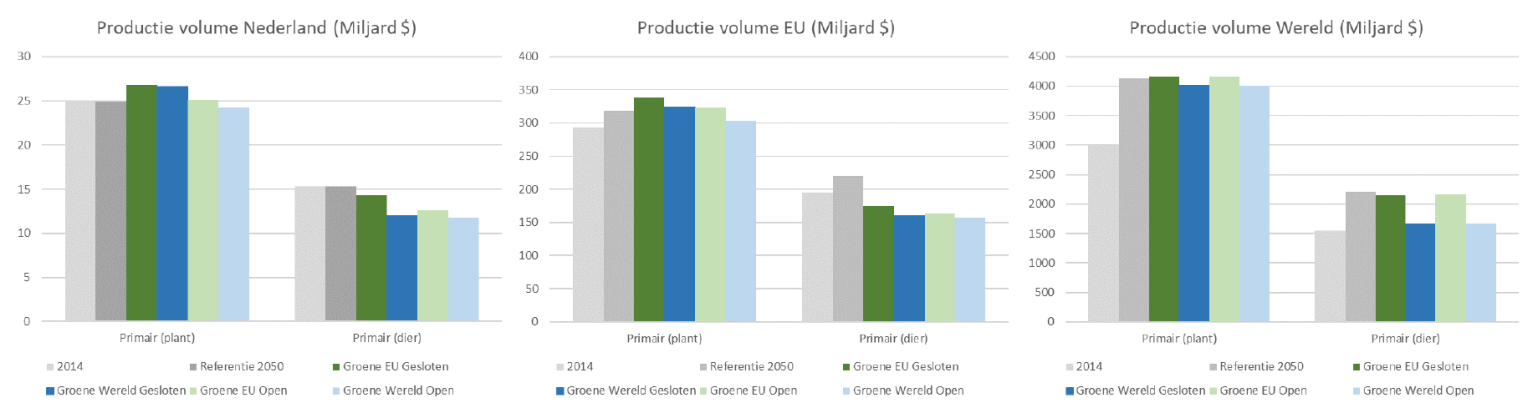

Figuur B1.10 Productievolumes 
In de vergroeningsscenario's daalt de dierlijke productie in de rest van de EU sterker dan in Nederland het geval is. Hier speelt het milieuruimte of 'milieuproductiequota' effect (zie Figuur B1.5) op basis van bestaand milieubeleid een rol dat de uitbreiding beperkt in het referentiescenario en bij vergroening de inkrimping ook beperkt. Ook het positieve effect op de voedselverwerkende industrie is alleen in Nederland duidelijk aanwezig. Hier speelt de geringe daling van de primaire dierlijke productie een rol en daarnaast doordat de op exportgerichte Nederlandse voedselverwerkende industrie meer profiteert van het reduceren van voedselverspilling. De primaire (plant) sector lijkt in Oost-Europa harder geraakt te worden dan in West-Europa, dit heeft onder andere te maken met de relatief hoge emissie intensiteit van de primair (plantaardige) sector in Oost-Europa.

Tabel B1.5 Productievolumes voor Europese regio's en rest van de Wereld, in miljard USD (\% tussen haakjes is verschil ten opzichte van referentie in 2050)

\begin{tabular}{|c|c|c|c|c|c|c|}
\hline Region_agg2 & 2014 & 2050: Referentie & 2050: Groen EU, Gesloten & 2050: Groen Wrld, Gesloten & 2050: Groen EU, Open & 2050: Groen Wrld, Open \\
\hline$\boxminus \mathbf{N L}$ & 145 & 162 & $175(8 \%)$ & $158(-2 \%)$ & $166(2 \%)$ & $153(-5 \%)$ \\
\hline Primair (plant) & 25.1 & 24.9 & $26.8(8 \%)$ & $26.6(7 \%)$ & $25.1(1 \%)$ & $24.2(-3 \%)$ \\
\hline Verwerkt & 105 & 122 & $134(10 \%)$ & $120(-2 \%)$ & $128(5 \%)$ & $117(-4 \%)$ \\
\hline$\Xi$ EU West & 1412 & 1565 & $1550(-1 \%)$ & $1457(-7 \%)$ & $1504(-4 \%)$ & $1418(-9 \%)$ \\
\hline Primair (plant) & 216 & 238 & $256(8 \%)$ & $244(3 \%)$ & $244(3 \%)$ & $227(-5 \%)$ \\
\hline$\boxminus$ EU East & 258 & 256 & $246(-4 \%)$ & $232(-10 \%)$ & $242(-6 \%)$ & $229(-11 \%)$ \\
\hline Primair (plant) & 51.2 & 55.4 & $55.4(0 \%)$ & $52.5(-5 \%)$ & $54.5(-2 \%)$ & $51.5(-7 \%)$ \\
\hline Primair (dier) & 36.0 & 37.5 & $29.4(-22 \%)$ & $27.4(-27 \%)$ & $28.0(-25 \%)$ & $27.1(-28 \%)$ \\
\hline Verwerkt & 170 & 163 & $161(-1 \%)$ & $152(-7 \%)$ & $159(-2 \%)$ & $150(-8 \%)$ \\
\hline$\boxminus$ Europe other & 344 & 369 & $359(-3 \%)$ & $372(1 \%)$ & $358(-3 \%)$ & $351(-5 \%)$ \\
\hline Primair (plant) & 2680 & 3778 & $3788(0 \%)$ & $3647(-3 \%)$ & $3800(1 \%)$ & $3662(-3 \%)$ \\
\hline Primair (dier) & 1308 & 1938 & $1925(-1 \%)$ & $1462(-25 \%)$ & $1949(1 \%)$ & $1483(-23 \%)$ \\
\hline Verwerkt & 5710 & 7371 & $7343(0 \%)$ & $7134(-3 \%)$ & $7357(0 \%)$ & $7094(-4 \%)$ \\
\hline$\boxminus$ World & 11858 & 15439 & $15386(0 \%)$ & $14461(-6 \%)$ & $15374(0 \%)$ & $14391(-7 \%)$ \\
\hline Primair (plant) & 3006 & 4135 & $4165(1 \%)$ & $4015(-3 \%)$ & $4162(1 \%)$ & $4005(-3 \%)$ \\
\hline Primair (dier) & 1545 & 2205 & $2146(-3 \%)$ & $1658(-25 \%)$ & $2158(-2 \%)$ & $1674(-24 \%)$ \\
\hline Verwerkt & 7307 & 9098 & $9074(0 \%)$ & $8788(-3 \%)$ & $9054(0 \%)$ & $8712(-4 \%)$ \\
\hline
\end{tabular}

\section{B1.3.2.1 Decompositie productievolume}

Figuur B1.11 toont de decompositie van de productievolumes in Nederland onder verschillende scenario's. De totale verandering van 2014-2050 is opgesplitst in de verschillende onderdelen die in box B1.2 nader zijn uitgelegd. In bijlage 0 zijn de decomposities voor andere regio's getoond. 
Box B1.2 Decompositieanalyse

Het referentiescenario en de 4 vergroeningsscenario's zijn een samenstelling van vele aannames die elkaar deels versterken en deels mitigeren. Om meer zicht te krijgen op de invloed van specifieke aannames kan MAGNET decompositieanalyses uitvoeren waarin het pakket van maatregelen wordt uiteengerafeld in een aantal categorieën van gelijksoortige aannames. Via een decompositie kan het model schatten hoe groot de impact van de verschillende aannames is op het uiteindelijke resultaat (\% verandering ten opzicht van 2014). In de uitkomsten wordt voor elke van deze bijdrages dus een procentuele verandering uitgerekend, waarbij de individuele bijdragen dan optellen tot de procentuele verandering van het eindresultaat. We delen hier de bijdrages op in:

$\mathrm{CO}_{2}$ eq-taks:

Dieet:

Voedselverspilling:

Handel (Voorkeur):

Handel (Tarieven):
Effect van $\mathrm{CO}_{2}$ eq-taksen de MAC-curves, wat een prijsverhogend effect heeft.

Effect van $-30 \%$ vleesconsumptie, wat een lagere vraag naar dierlijk producten geeft en een hogere vraag naar plantaardige producten. De indirecte vraag naar voerdergewassen daalt ook.

Effect van 33\% minder voedselverspilling in de hele keten. De implementatie komt neer op een efficiëntieslag met een verlagend effect op de marktprijs.

Implementatie van de '20\%' lokale preferentie. Sterk effect op handelsstromen, waarbij voorkeur voor producten binnen EU duidelijk handelsstromen verlaagt.

Implementatie van compenserende tarieven of afschaffing tarieven. Helpen productie/ export op peil te houden bij implementatie van de $\mathrm{CO}_{2}$-eq-taks in het groen gesloten EU-scenario waar deze compenserende tarieven in de verhaallijn worden verondersteld. Voor scenario's waar handelsbelemmeringen worden verlaagd betekent dit dus verlaging barrières, met wat meer handel tot gevolg, gezien de reguliere importtarieven heeft dit vooral effect op vlees. Zie ook Tabel B1.4.

Afname landbouwgrond: De afname van landbouwareaal door ontwikkelingen buiten de landbouw (extra aanname Nederland) en door extra bescherming biodiversiteit. Wereldwijd is dit met name afname landbouwgronden wat een direct verhogend prijseffect heeft en leidt tot licht dalende primaire productie.

Milieuproductiequota: De aanname voor een bindende milieu ruimte voor veeteelt op basis van bestaand milieubeleid in de referentie (Lesschen et al., 2020). Dit is geïmplementeerd via een milieuproductiequota en bijbehorende simpele productiebelasting/quota rent.

Macro:
Macro-effecten (BBP, populatie) en land specifieke effecten van het referentiescenario, productiviteit aannames van industrie maar ook gewasopbrengsten en voederconversies, energieprijzen. Deze effecten drijven de vraag, productie etc. 


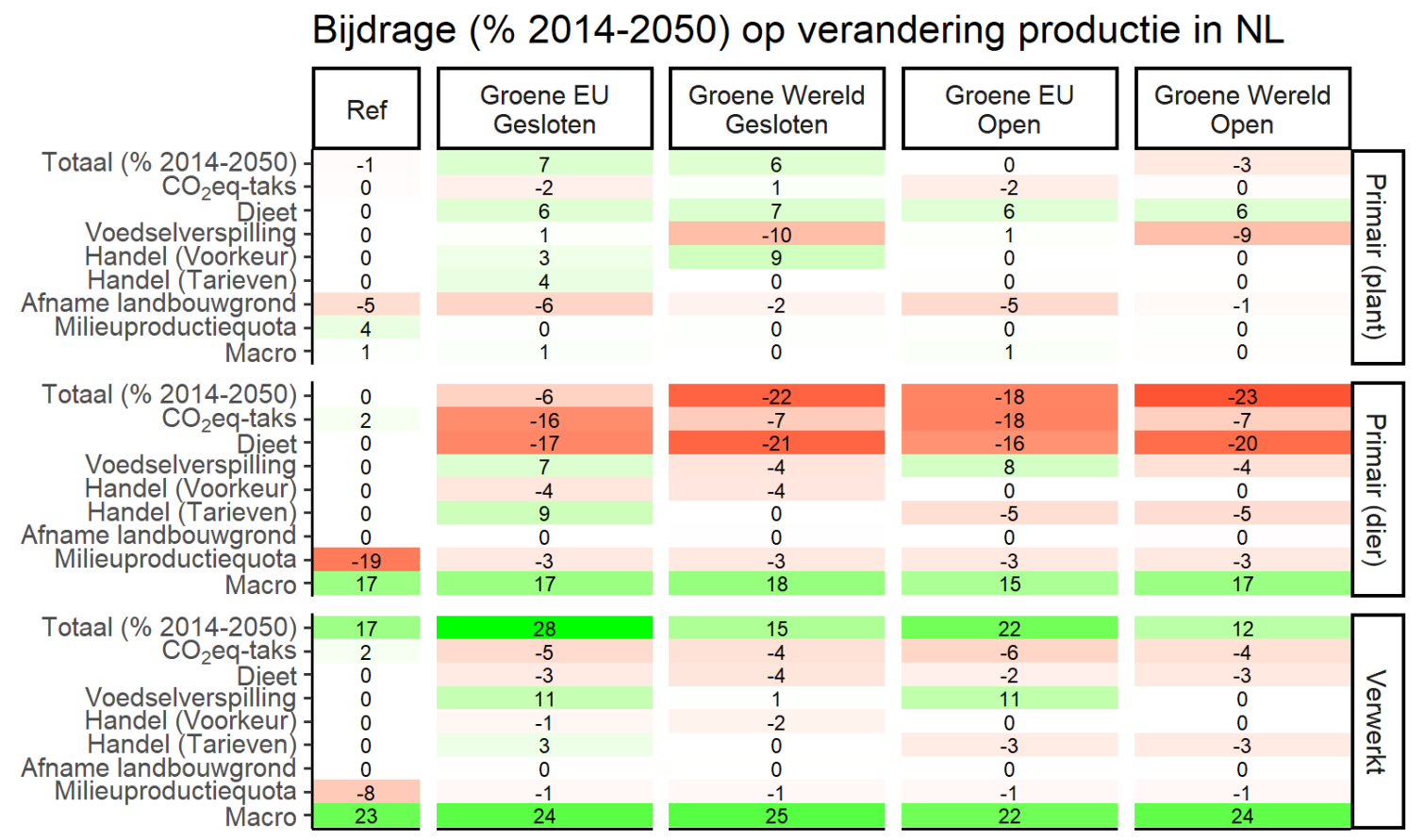

Figuur B1.11 Decompositie van productieverandering (2014-2050), Nederland

De decompositieanalyse rafelt het totale effect uiteen naar de bijdrage van alle separate aannames. Figuur B1.11 toont de decompositieanalyse voor de Nederlandse productie. Hieruit blijkt dat de macroeffecten BBP en populatiegroei met name leiden tot groei voor dierlijke en verwerkte producten door hogere inkomenselasticiteiten (als besteedbaar inkomen groeit wordt een groter deel van het inkomen besteed aan dierlijke producten en verwerkte producten dan plantaardige producten (zoals rijst en granen). Voor plantaardige producten is dit macro effect verwaarloosbaar.

In het referentiescenario wordt de potentiële groei van dierlijke productie in Nederland op basis van macro-effecten (17\%) en de beperkte $\mathrm{CO}_{2}$-eq-taks van de ETS tot 2020 (2\%) wordt in Nederland niet bereikt doordat het huidige milieubeleid bindend is $(-19 \%$, het milieuproductiequota effect). Hierdoor is de groei in het referentiescenario niet $19 \%$, wat op basis van de macro-effecten en $\mathrm{CO}_{2}$-eq-taks theoretisch verwacht kan worden maar blijft de productie constant. Dit wordt in het model bereikt door een belasting (quota rent, zie Figuur B1.5). Het huidige milieubeleid voor dierlijke sectoren werkt ook negatief door in de voedselverwerkende industrie $(-8 \%)$. De afname van landbouwgrond treft met name de plataardige sectoren $(-5 \%)$. In de vier vergroeningsscenario's daalt de productie van dieren zover dat het milieuproductiequota op basis bestaand beleid niet meer bindend is en daarom is de compenserende productie taks (quota rent) niet meer nodig en verdwijnt het effect (er is een restant aanwezig van $3 \%$ aangezien het milieuproductiequota nog wel geïmplementeerd is in de periode 2014-2020). Het resterende negatieve effect van de categorie afname landbouwgrond komt door de introductie van extra herbebossing/uit productie halen van veengrond en extra bescherming van biodiversiteitsrijke gebieden (dat laatste punt heeft vooral effect in de rest van de Wereld).

Het Groene EU Gesloten-scenario leidt tot hoogste agrifoodproductie in Nederland. Wereldwijde vergroening en open markten verlagen de Nederlandse productie. Reductie van voedselverspilling eenzijdig in de EU leidt tot kostenverlaging en concurrentievoordeel wat zeker voor de exportgeoriënteerde voedselverwerkende industrie een positief effect op de productie heeft.

Wat betreft de biodiversiteitsbescherming (afname landbouwgrond), is er een compenserend effect vooral voor plantaardige productie bij invoering biodiversiteitsbescherming wereldwijd. In de rest van de wereld heeft bescherming een grotere impact omdat daar meer biodiversiteit beschermd wordt vanwege de aanwezigheid van meer natuurgebied wat nog niet beschermd is. Dit leidt daar tot een relatief hogere landprijs en daardoor productieverandering dan in de EU (maatregelen pakken strenger uit in extra bescherming tropische gebieden, waar in EU minder bossen met grote biodiversiteit 
beschikbaar zijn of al voor een groter deel beschermd is). Dus het negatieve effect van de extra biodiversiteitsbescherming in EU-setting wordt daarmee deels opgeheven.

\section{B1.3.2.2 Detail sectoren}

Indien men kijkt naar detail met betrekking tot de sectoren, dan valt op dat binnen de dierensectoren de melkveehouderij er positiever uitkomt dan de vleessectoren.

Tabel B1.6 Productievolumes met de primaire (dier)sector uitgesplitst naar melk- en vleessectoren in miljard USD (\% tussen haakjes is verschil ten opzichte van referentie in 2050)

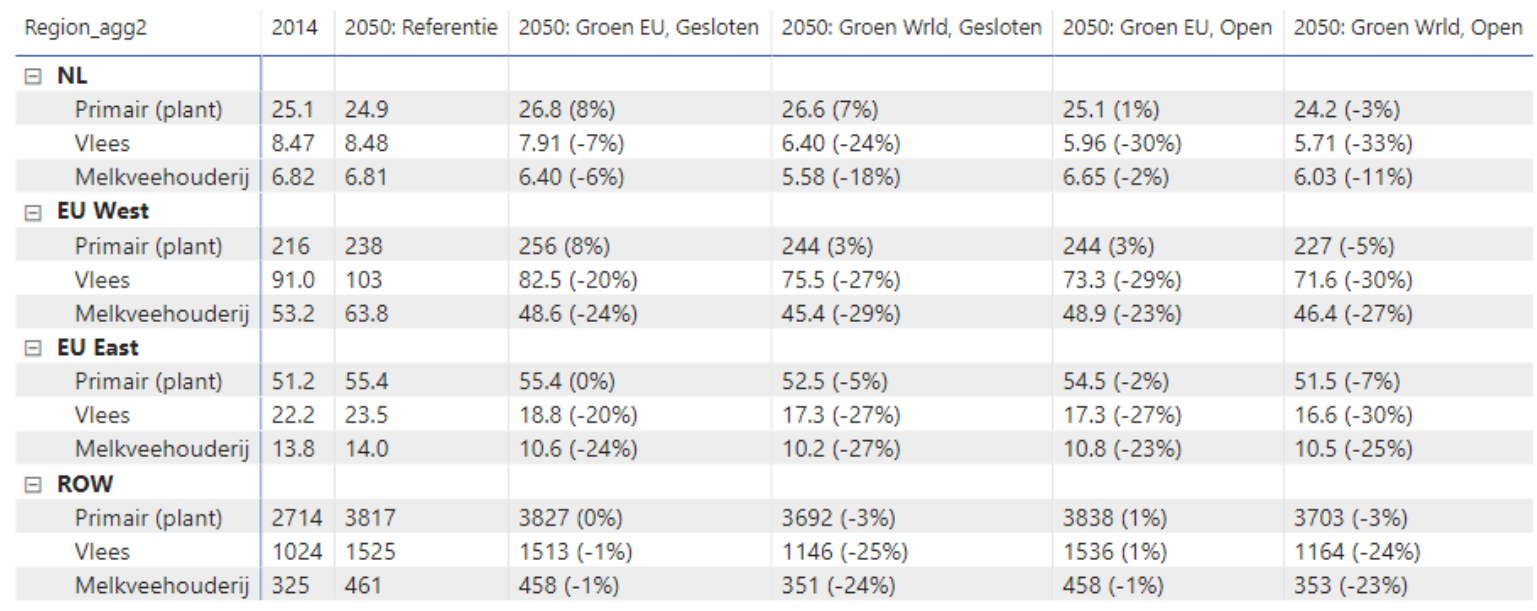

De melkveehouderij krimpt meer indien de vergroening wereldwijd is dan alleen binnen de EU $(-11 \%$ tot $-18 \%$ versus, $-2 \%$ tot $-6 \%$ ). Dit komt met name door dieetverandering, $\mathrm{CO}_{2}$-eq-taks, en de reductie van voedselverspilling die tot minder vraag leiden voor de sterk internationaal gerichte melkveehouderij (zie Figuur B1.12). Vanwege het internationale karakter van deze sector zijn de open handel scenario's altijd gunstiger met betrekking tot productieontwikkeling dan de gesloten handel scenario's (4\% hogere productie in geval Groene EU Open scenario en 6\% in geval Groene Wereld Open scenario's ten opzichte van de gesloten varianten). Voor de sterk met import concurrerende vleessectoren is dit beeld omgekeerd. Voor deze sectoren zijn de open handel scenario's veel bedreigender. In het geval dat de EU eenzijdig vergroent is vermindering dierlijke productie $7 \%$ bij gesloten handel en $-30 \%$ bij open handel. De compenserende $\mathrm{CO}_{2}$-invoerbelasting $(+14 \%)$ en de relatief hoge tariefbescherming $(-9 \%,-10 \%)$ spelen een grote rol in dit verschil (zie Handle (tarieven effect). De wereldwijde vergroeningsscenario's zijn ook negatiever voor de vleessectoren omdat de vraag naar vlees nog meer terugloopt door dieetverandering, vermindering voedselverspilling en $\mathrm{CO}_{2}$ eq-taks. 


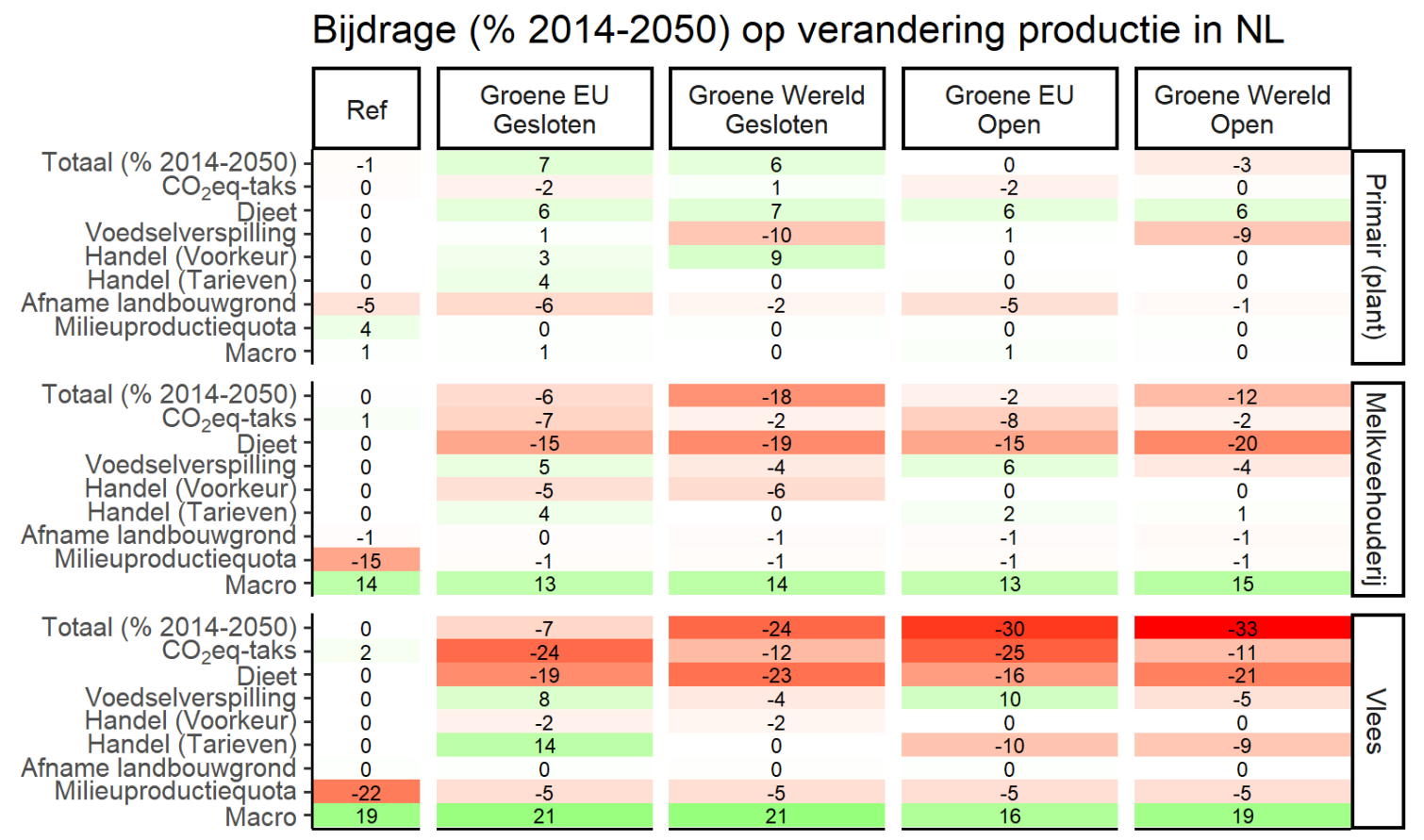

Figuur B1.12 Decompositie van productieverandering met detail vlees en melk (2014-2050), Nederland

\section{B1.3.3 Landgebruik}

Figuur B1.13 toont landgebruik voor 2014 en voor 2050 voor de scenario uitkomsten, voor Nederland, de EU, en Wereldwijd. De combinatie van de voorgeschreven daling van landbouwareaal in het referentiescenario in Nederland met het dierlijke milieuproductiequota uit zich in een sterke reductie van grasland (i.e. primair dierlijk) en in mindere mate van landgebruik voor primair plant (zie ook Figuur B1.14). Wanneer we in Nederland en Europa de referentie-uitkomst in 2050 met de scenario's vergelijken, is duidelijk dat het graslandareaal minder hard daalt dan de productie: er vindt dus extensivering plaats. Het blijft economisch interessant om het land te blijven bewerken maar minder intensief. Het land is in Nederland zo vruchtbaar, zo schaars en wordt zo intensief bewerkt dat het in productie blijft ook al neemt de intensiteit af. Er zijn bijna geen marginale gronden. Op wereldschaal neemt het areaal substantieel af in het geval van wereldwijde vergroening. De lagere vraag naar landbouwproducten leidt hier tot uit productie nemen of niet uitbreiden van agrarisch land. Land op wereldschaal is minder schaars en minder productieve gebieden zullen uit productie worden genomen omdat het niet meer rendabel is.
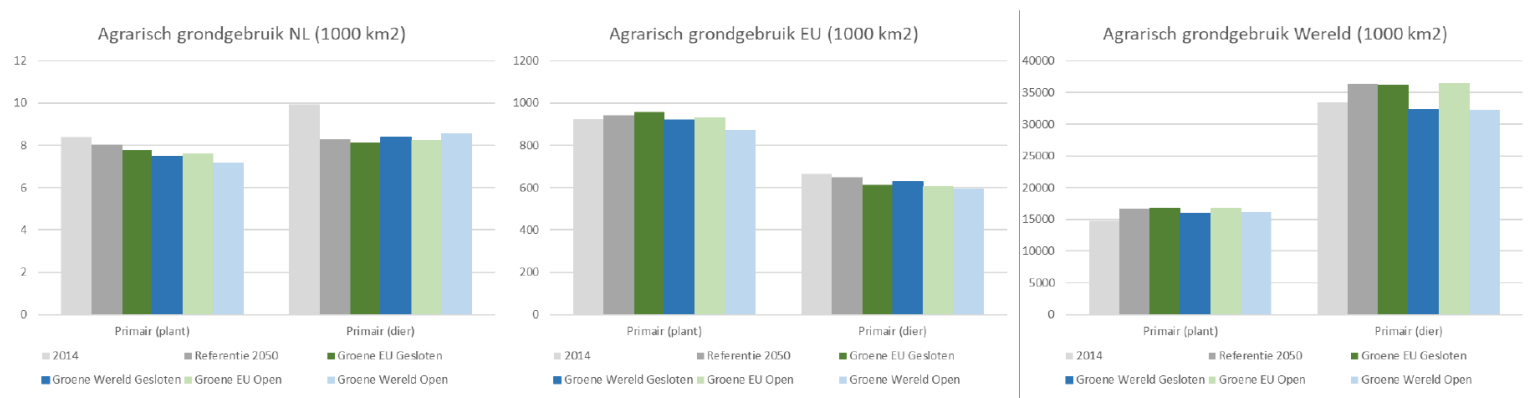

Figuur B1.13 Landgebruik 
Tabel B1.7 Landgebruik in $1.000 \mathrm{~km}^{2}$ voor Europese regio's en rest van de Wereld (\% tussen haakjes is verschil ten opzichte van referentie in 2050)

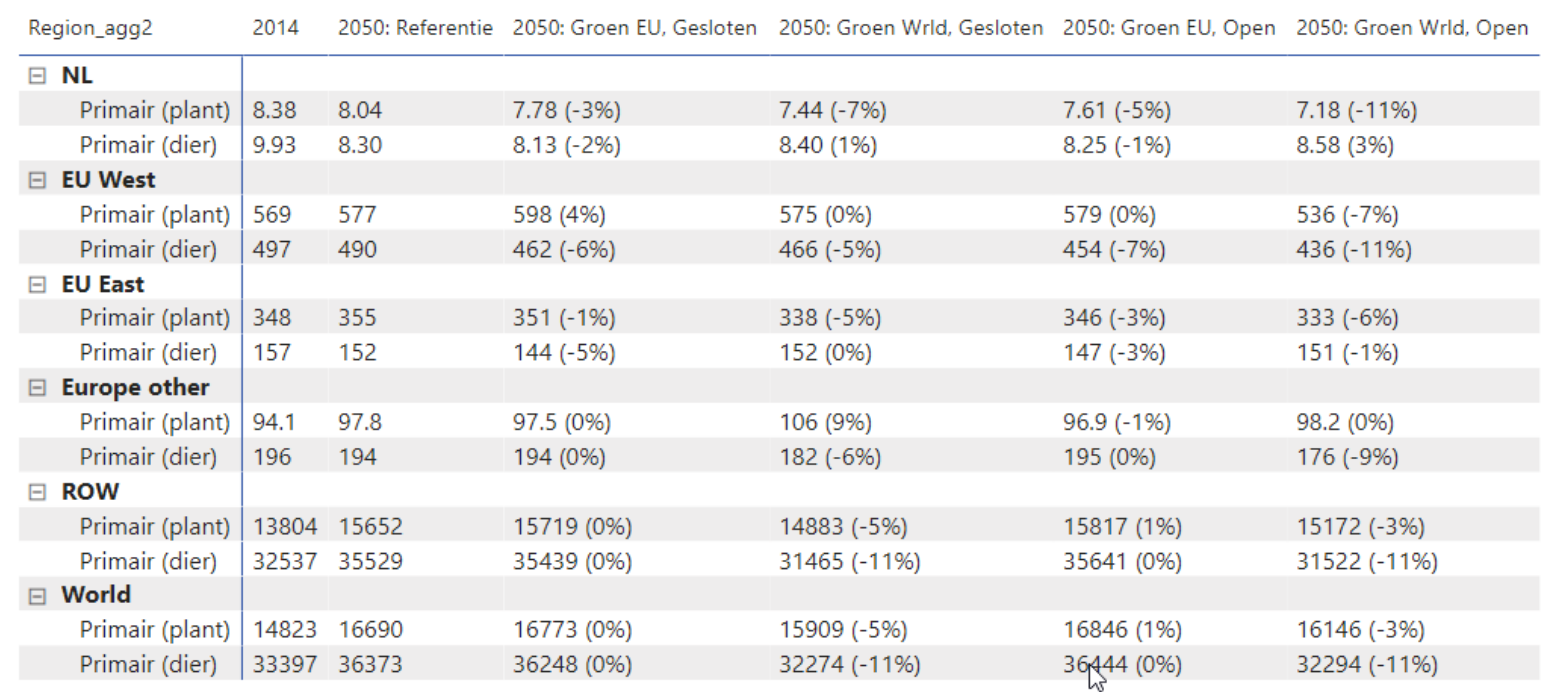

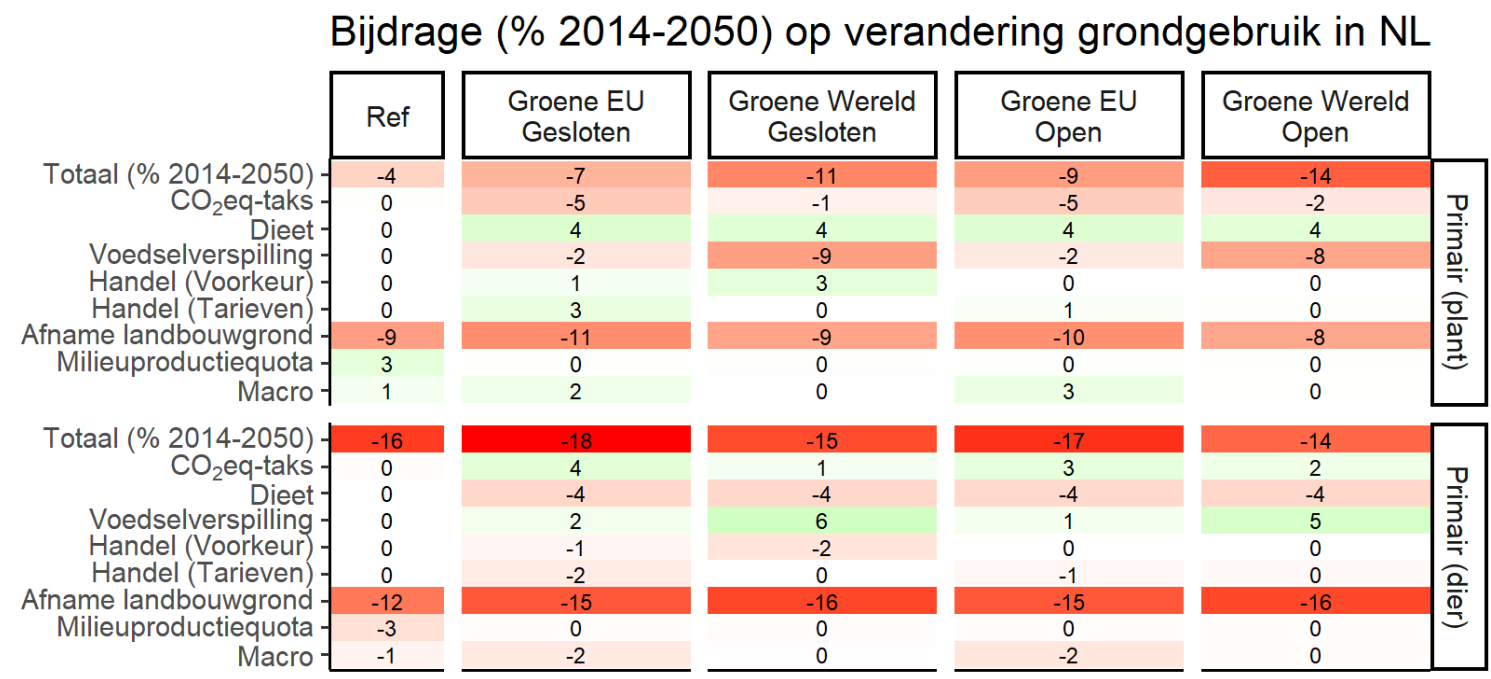

Figuur B1.14 Decompositie van verandering grondgebruik (2014-2050), Nederland

\section{B1.3.4 Broeikasgasemissies}

Figuur B1.15 toont broeikasgasemissies voor 2014 en voor 2050 voor de scenario-uitkomsten, voor Nederland, EU, en Wereldwijd. Duidelijk is de circa $40 \%$ afname van emissies in de primair dierlijke sector en een iets lagere daling in de plantaardige sector. De primair plantaardige sector daalt qua emissie intensiteit en productievolume minder dan de dierlijke sector).
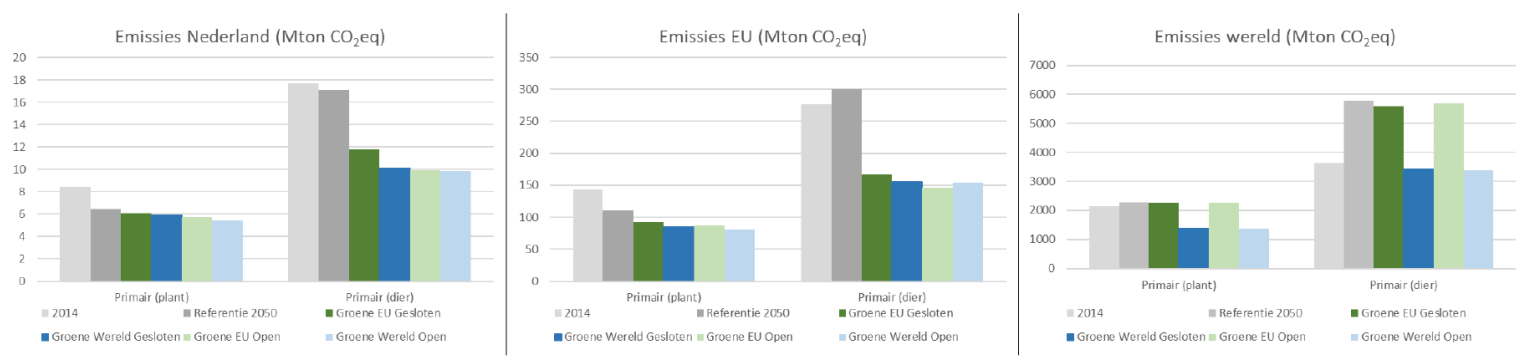

Figuur B1.15 Landbouwemissies 
Hoewel het lastig is de emissiedalingen direct te vergelijken met andere studies, is de daling van de emissies van richting de $50 \%$ wel in lijn met bijvoorbeeld de voorgenomen scenario's van Lesschen et al. 2020 (zie bijvoorbeeld Figuur 13 in die publicatie). En hoewel de scope en definities anders zijn, dalen volgens het PBL in een recent rapport, in een scenario met eenzelfde dieetaanname, de emissies met bijna 40\% (Westhoek, 2019).

Tabel B1.8 Totale emissies van primaire sectoren in $\mathrm{Mt} \mathrm{CO}_{2}$-eq voor Europese regio's en rest van de Wereld (\% tussen haakjes is verschil ten opzichte van referentie in 2050)

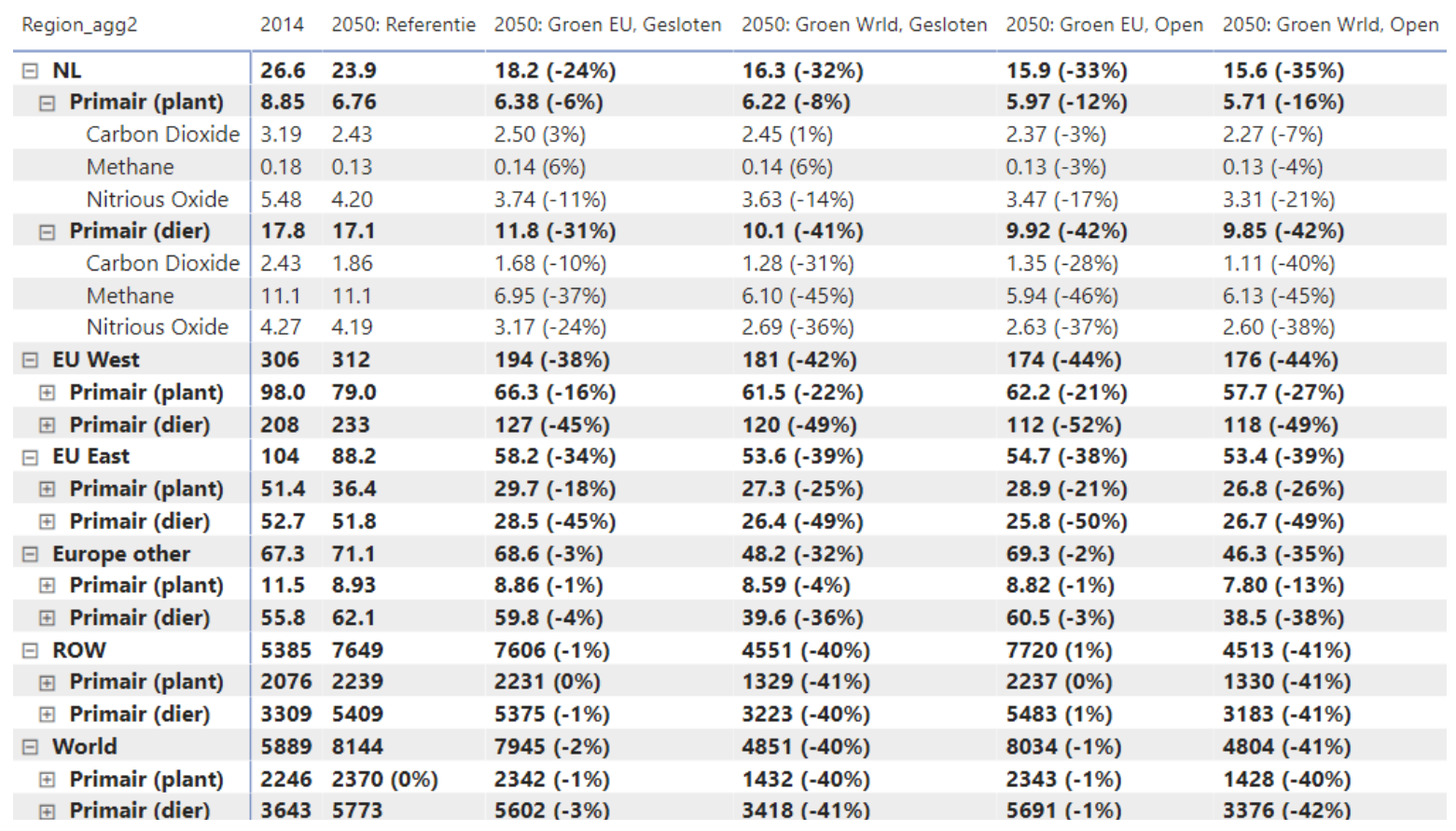

Opdeling naar type broeikasgas (zie Figuur B1.16) laat zien dat methaan relatief de grootste bron van afname is ten opzichte van van de referentie 2050-uitkomsten. Wereldwijd speelt dit ook een belangrijke rol (ook voor planten, waar methaanemissies van rijstteelt een belangrijke bron zijn).
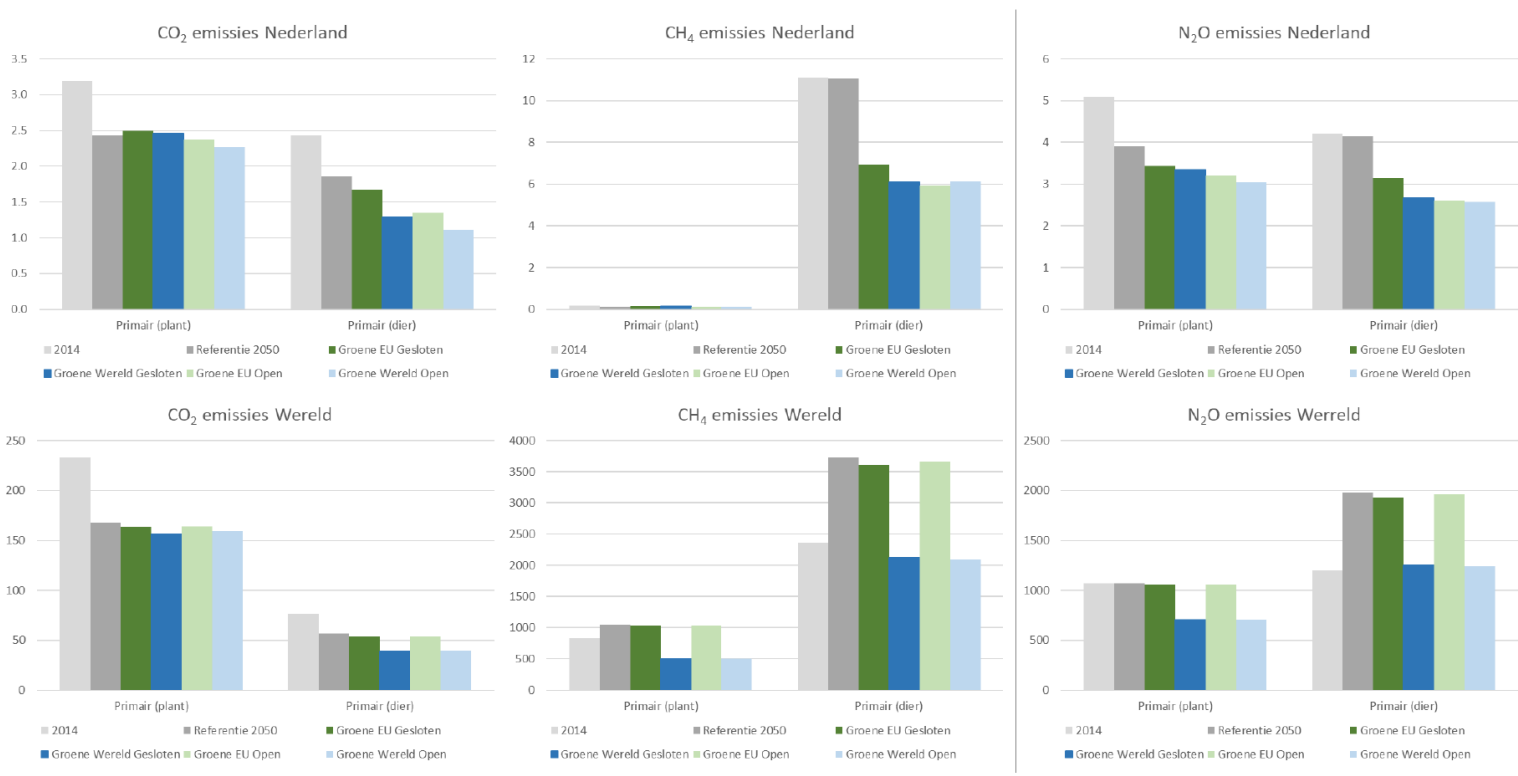

Figuur B1.16 Emissies Nederland en Wereld, per broeikasgas 
De afname van broeikasgasemissies in de referentie komt enerzijds door een aanwezige autonome verbetering qua efficiëntie van inputs door technologische vooruitgang, anderzijds een licht verschuiven van energie-intensieve gewassen naar bijvoorbeeld iets meer productie van tarwe en andere granen. De methaanemissies zijn veelal verbonden aan de activiteiten op de boerderij die minder eenvoudig gereduceerd kunnen worden tenzij de consumptie sterk vermindert. De beprijzing van emissies is in de referentie beperkt waardoor technische mogelijkheden niet worden geïntroduceerd (deze worden geïntroduceerd in model via de MAC-curves en zonder beprijzing wordt er geen vooruitgang geboekt). De $\mathrm{N}_{2} \mathrm{O}$-emissies zijn in de plantaardige sector vooral verbonden aan kunstmestgebruik (en kunnen dus autonoom afnemen door energiebesparing) maar voor de dierlijke sector voornamelijk als 'activiteit' emissie op de boerderij, die net als bij $\mathrm{CH}_{4}$ alleen spontaan afnemen bij reductie consumptie of bij beprijzing van emissies in combinatie met implementatie van de MACcurves.

\section{B1.3.4.1 Decompositie emissies}

Uit de decompositie van de invloed van aannames op emissies, zie Figuur B1.17, is duidelijk dat voor de primaire dierlijke sector de emissies voornamelijk dalen door $\mathrm{CO}_{2}$-eq-taks en dieetverandering. In de plantaardige sector zijn naast de $\mathrm{CO}_{2}$-eq-taks ook efficiëntieverbetering in de keten (door macroproductiviteit, substitutie-effecten en vermindering voedselverspilling) belangrijk. Deze efficiëntieverbeteringen op het gebruik van inputs zoals kunstmest en energie worden veroorzaakt door technologische trends (die geïmplementeerd zijn als externe aannames) en door substitutieeffecten weg van duurdere inputs (bijvoorbeeld door de $\mathrm{CO}_{2}$-eq-taks op kunstmest schakelen boeren over op organische mest). In bijlage 0 zijn de decomposities voor andere regio's getoond.

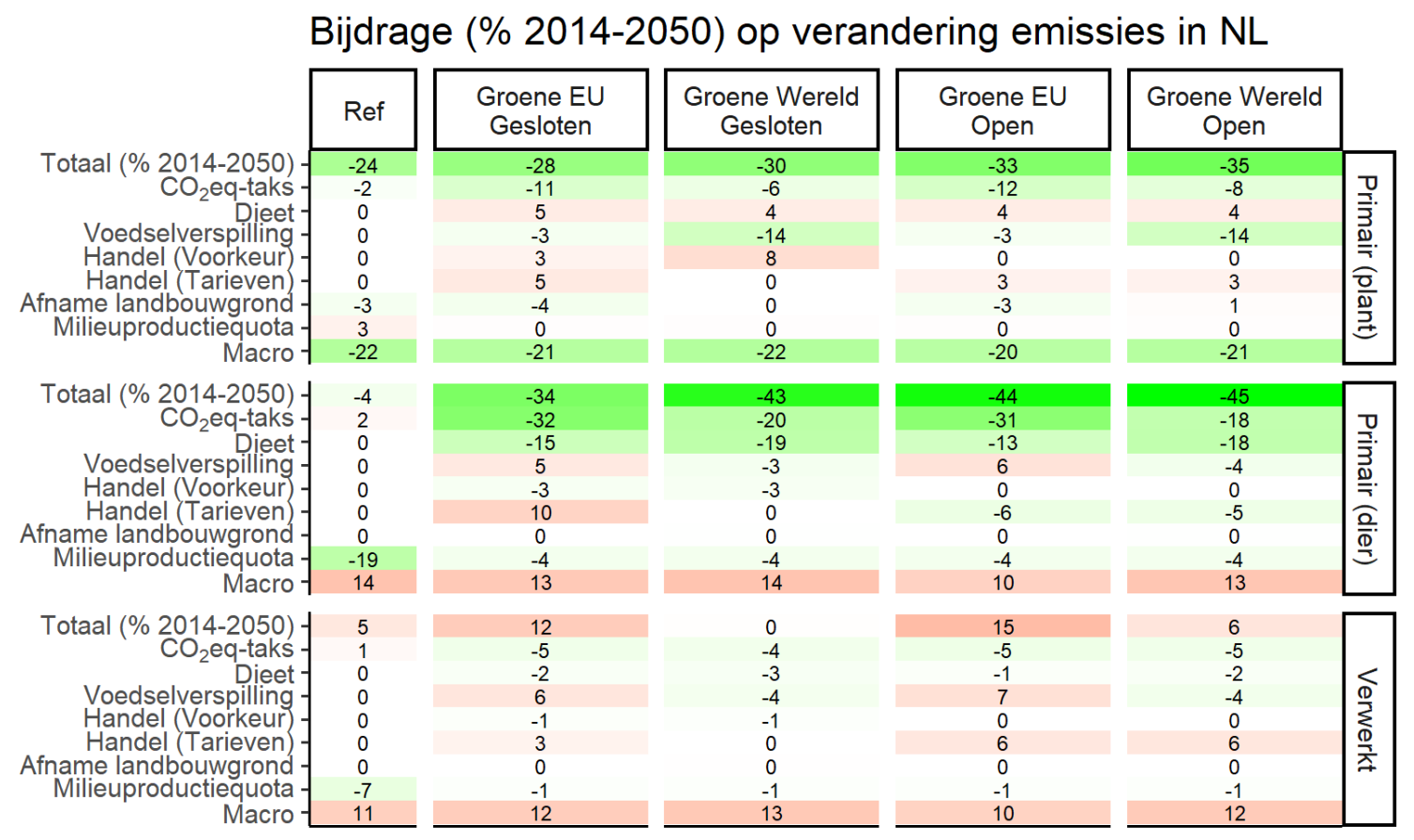

Figuur B1.17 Decompositie van emissieverandering (2014-2050), Nederland

\section{B1.3.5 Prijzen}

Figuur B1.18 toont productieprijzen (voor agrifood evenals voor geaggregeerde diensten ('services'), industrie en energiesectoren) voor 2014 en voor 2050 voor de scenario-uitkomsten voor Nederland en Figuur B1.19 toont deze prijzen voor de wereld.

In het referentiescenario is reeds sprake van een daling van prijzen in agrifoodsectoren conform historische trends. Dit komt door relatief hoge productiviteitsgroei in de agrifoodsectoren in combinatie met relatief lage inkomenselasticiteiten. De combinatie van hoge productiviteitsgroei (minder productiefactoren nodig om hetzelfde te produceren) gecombineerd met een inelastische 
vraag leidt tot een dalend aandeel van de landbouw in de economie (BBP). In het referentiescenario stijgen met name de prijzen van diensten en energie (dit laatste is een externe model aanname gebaseerd op het IEA-scenario). Vooral het scenario Groene EU Gesloten EU geeft een verhoging van de prijs voor plantaardige productie door de groei van deze sector, terwijl de prijs van primair dierlijke producten daalt door dalende vraag.

Productieprijzen Nederland 2050 (percentage verandering tov 2014)

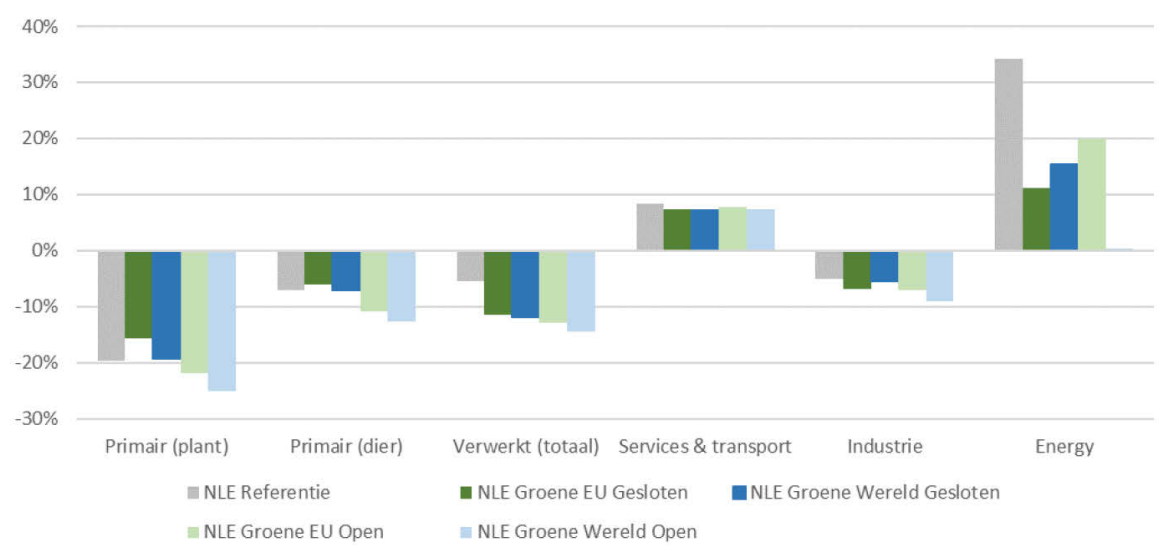

Figuur B1.18 Productieprijzen Nederland

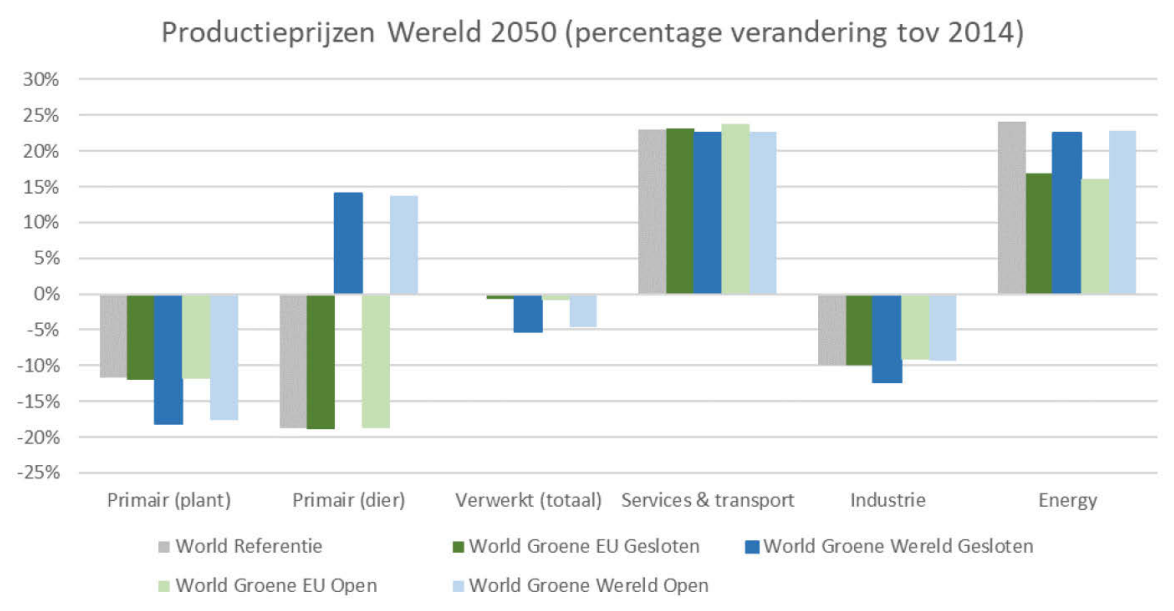

Figuur B1.19 Productieprijzen Wereld 
Tabel B1.9 Index productieprijzen voor Europese regio's en rest van de Wereld (\% tussen haakjes is verschil ten opzichte van referentie in 2050)

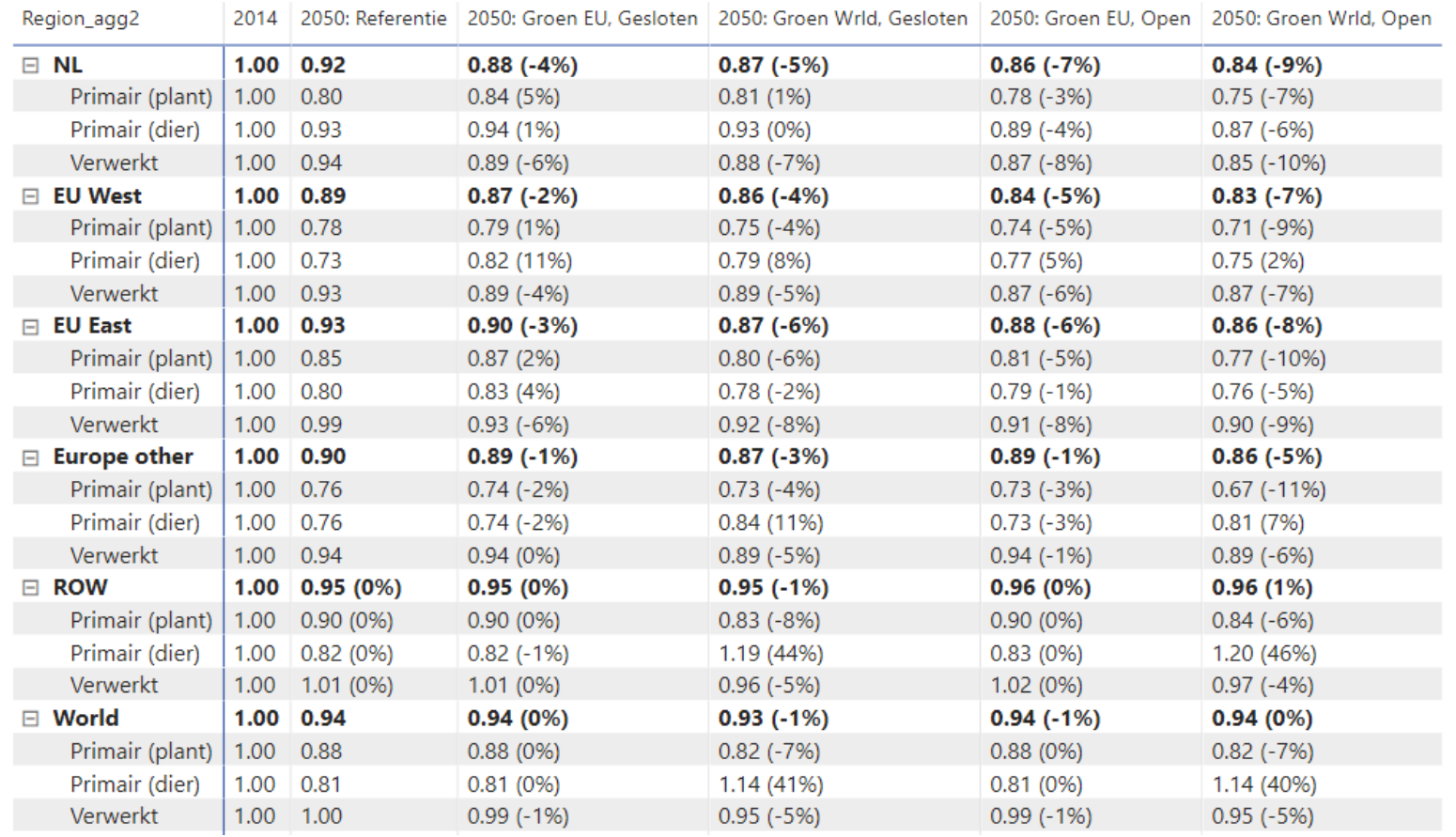

\section{B1.3.5.1 Decompositie productieprijzen}

Figuur B1.20 geeft de decompositie van prijsveranderingen in Nederland (bijlage 0 geeft extra grafieken voor Europese en Wereldregio's). Dalende prijzen in het referentiescenario worden met name bepaald door macro trends (met name de relatief hoge productiviteitsgroei ten opzichte van andere sectoren en beperkte groei van de vraag als het inkomen stijgt). De daling is relatief sterk in plantaardige sectoren $(-21 \%)$, waar de vraag ook minder elastisch is dan voor vlees $(-18 \%)$ en verwerkte producten $(-7 \%)$.

$\mathrm{Er}$ is een sterke stijging van prijzen vooral in dierlijke sector bij introductie van de $\mathrm{CO}_{2}$-eq-taks (19\% tot $25 \%)$ terwijl deze voor plantaardige productie (4\%-10\%) en verwerkte industrie (2\%-6\%) beperkter is. De hogere prijsstijgingen binnen de gespecificeerde ranges doen zich telkens voor als de gehele wereld vergroent. Dit effect wordt licht versterkt door compenserende invoertarieven (6\% in Groene EU Gesloten) en voorkeursverschuiving naar lokale producten. Dieetveranderingen en met name de reductie van voedselverspilling verlagen de prijs. Liberalisering van de wereldhandel heeft een beperkt drukkend effect op de prijzen. Voor de wereld in z'n geheel is dit een sterker effect dan in EU vanwege de reeds efficiëntere productie in de EU, die volgens de basisdata van het model aanwezig is. Het effect van de handelsvoorkeur voor binnenlandse producten is positief op de prijs (3\%-4\%) indien dit effect alleen binnen de EU optreedt, maar negatief $(-3 \%,-6 \%)$ indien dit wereldwijd gebeurt. 


\section{Bijdrage (\% 2014-2050) op productieprijs in NL}
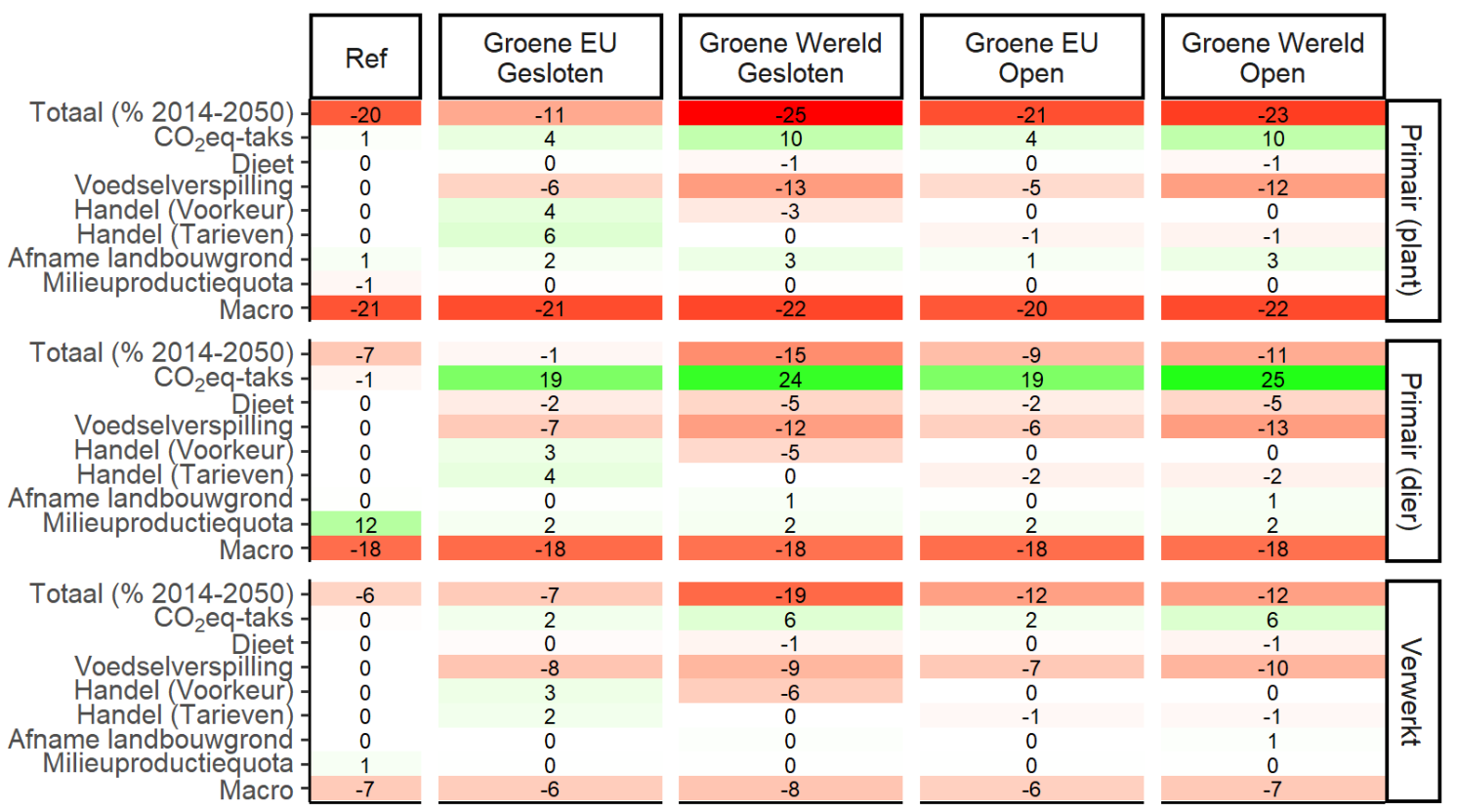

Figuur B1.20 Decompositie van prijsverandering (2014-2050), Nederland

\section{B1.3.6 Handel}

Figuur B1.21 toont import- en exportvolumes voor 2014 en voor 2050 voor de scenario-uitkomsten, voor Nederland van/naar de wereld uitgezonderd de EU, of van/naar EU regio's. Tabel B1.10 en Tabel B1.11 geven meer detail ook voor de twee EU-regio's.

De export wordt negatief beïnvloed door de $\mathrm{CO}_{2}$-eq-taks, maar gecompenseerd door compenserende tarieven en een betere concurrentiepositie door efficiëntie (minder voedselverspilling in de keten). Vooral het Groene Wereld, Gesloten scenario heeft een sterke negatieve impact op verwerkte export naar rest van de wereld door sterkere voorkeur voor lokale producten.
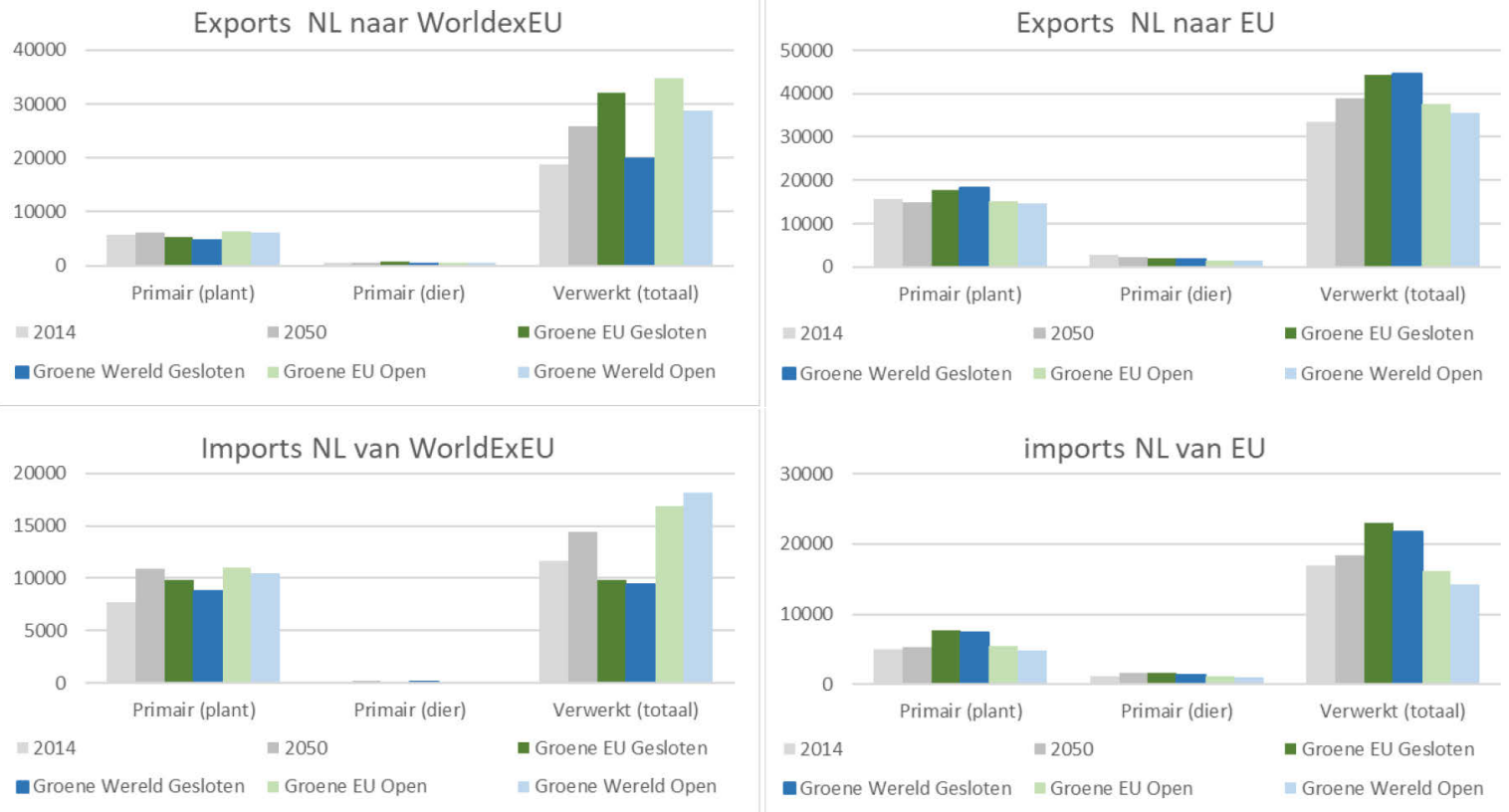

Figuur B1.21 Export- en importvolumes (miljoen dollar) Nederland 
Tabel B1.10 Exportvolumes in miljard USD voor Europese regio's (\% tussen haakjes is verschil ten opzichte van referentie in 2050)

\begin{tabular}{|c|c|c|c|c|c|c|}
\hline Region_agg2 & 2014 & 2050: Referentie & 2050: Groen EU, Gesloten & 2050: Groen Wrld, Gesloten & 2050: Groen EU, Open & 2050: Groen Wrld, Open \\
\hline$\boxminus \mathbf{N L}$ & 77.3 & 88.8 & $102(15 \%)$ & $89.4(1 \%)$ & $96.0(8 \%)$ & $86.9(-2 \%)$ \\
\hline$\boxminus$ Primair (plant) & 21.5 & 21.2 & $23.2(9 \%)$ & $23.0(8 \%)$ & $21.5(1 \%)$ & $20.7(-2 \%)$ \\
\hline EU & 15.7 & 15.0 & $17.8(19 \%)$ & $18.2(22 \%)$ & $15.1(1 \%)$ & $14.5(-3 \%)$ \\
\hline WorldExEU & 5.82 & 6.20 & $5.36(-14 \%)$ & $4.75(-23 \%)$ & $6.33(2 \%)$ & $6.14(-1 \%)$ \\
\hline$\boxminus$ Primair (dier) & 3.33 & 2.74 & $2.60(-5 \%)$ & $2.01(-27 \%)$ & $2.06(-25 \%)$ & $2.02(-26 \%)$ \\
\hline EU & 2.72 & 2.18 & $1.89(-13 \%)$ & $1.64(-25 \%)$ & $1.58(-27 \%)$ & $1.42(-35 \%)$ \\
\hline EU & 33.6 & 38.9 & $44.4(14 \%)$ & $44.6(15 \%)$ & $37.7(-3 \%)$ & $35.5(-9 \%)$ \\
\hline WorldExEU & 18.9 & 25.9 & $32.0(23 \%)$ & $19.8(-24 \%)$ & $34.8(34 \%)$ & $28.8(11 \%)$ \\
\hline$\boxminus$ EU West & 364 & 416 & $472(13 \%)$ & $393(-6 \%)$ & $450(8 \%)$ & $393(-6 \%)$ \\
\hline$\boxplus$ Primair (plant) & 58.3 & 61.0 & $74.0(21 \%)$ & $66.0(8 \%)$ & $64.8(6 \%)$ & $57.2(-6 \%)$ \\
\hline 由 Primair (dier) & 15.3 & 17.9 & $18.8(5 \%)$ & $14.9(-17 \%)$ & $15.5(-14 \%)$ & $15.9(-12 \%)$ \\
\hline Ð Verwerkt & 51.2 & 54.8 & $59.7(9 \%)$ & $51.0(-7 \%)$ & $58.0(6 \%)$ & $50.9(-7 \%)$ \\
\hline
\end{tabular}

Tabel B1.11 Importvolumes in miljard USD voor Europese regio's (\% tussen haakjes is verschil ten opzichte van referentie in 2050)

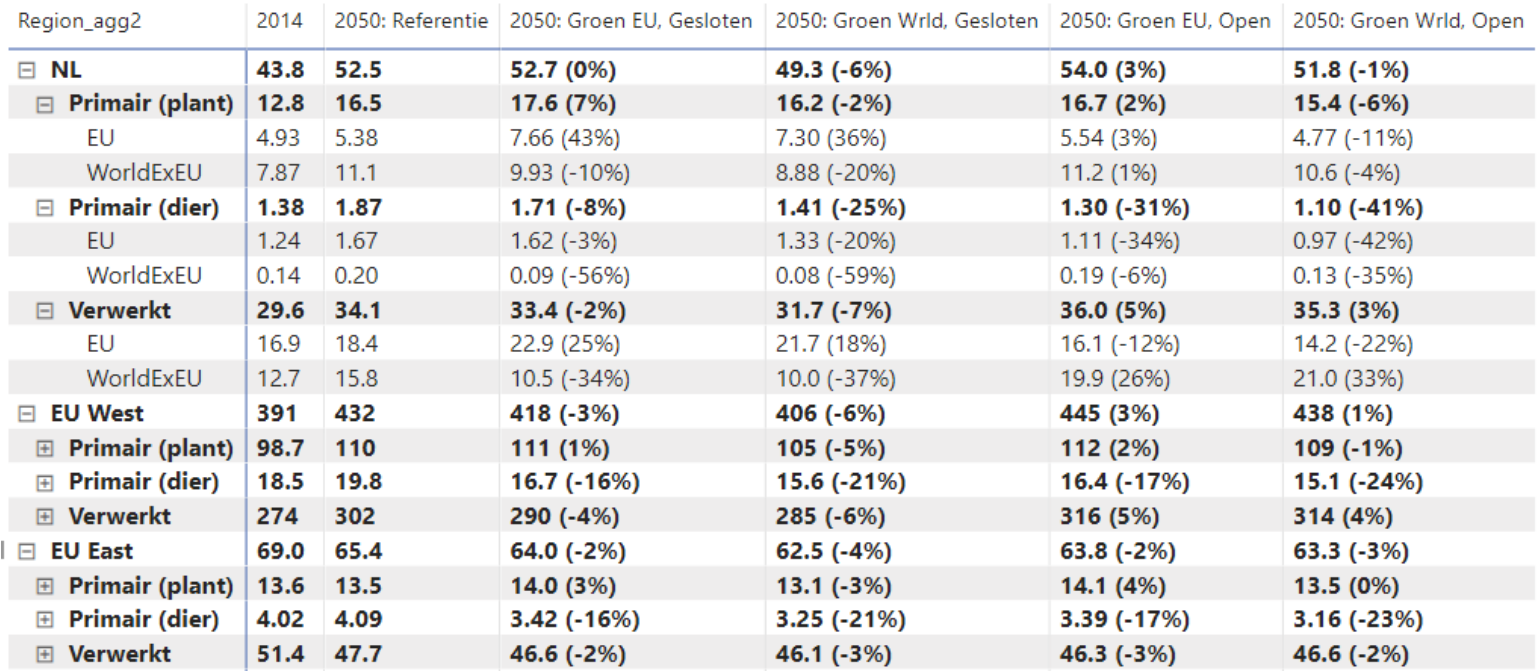

\section{B1.3.6.1 Decompositie export en import}

Figuur B1.22 en Figuur B1.23 geven de decompositie van import en export van Nederland naar/van buiten de EU. In bijlage 0 zijn deze grafieken ook voor de EU als geheel te zien.

In de decompositie is duidelijk te zien hoe de export na toepassing van $\mathrm{CO}_{2}$-eq-taks in het Groene $\mathrm{EU}$, Gesloten-scenario op peil gehouden wordt door de compenserende tarieven. In het Groene Wereld, Gesloten-scenario is duidelijk dat de verschuiving in voorkeur naar meer lokale producten een sterk drukkend effect heeft op zowel import als export. In scenario's met eenzijdige vergroening is ook opnieuw te zien hoe de reductie van voedselverspilling een exportvoordeel oplevert. Het afschaffen van tarieven/subsidies heeft met name een effect van verhoogde import in de verwerkte sector, maar heeft verder een redelijk klein effect. 


\section{Bijdrage (\% 2014-2050) op export NL naar WorldExEU}

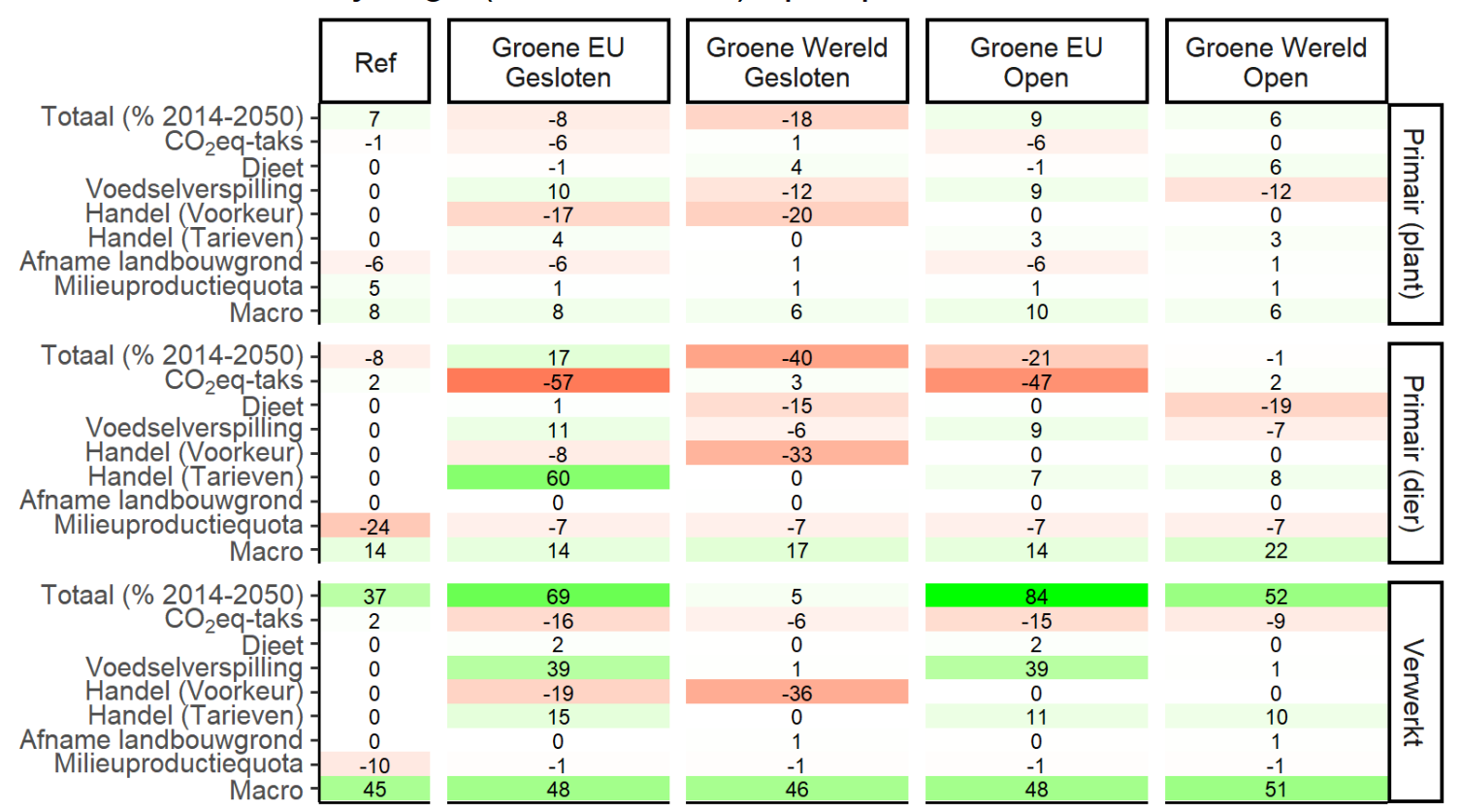

Figuur B1.22 Decompositie van exportverandering (2014-2050), Nederland naar Wereld buiten EU

\section{Bijdrage (\% 2014-2050) op import NL van WorldExEU}

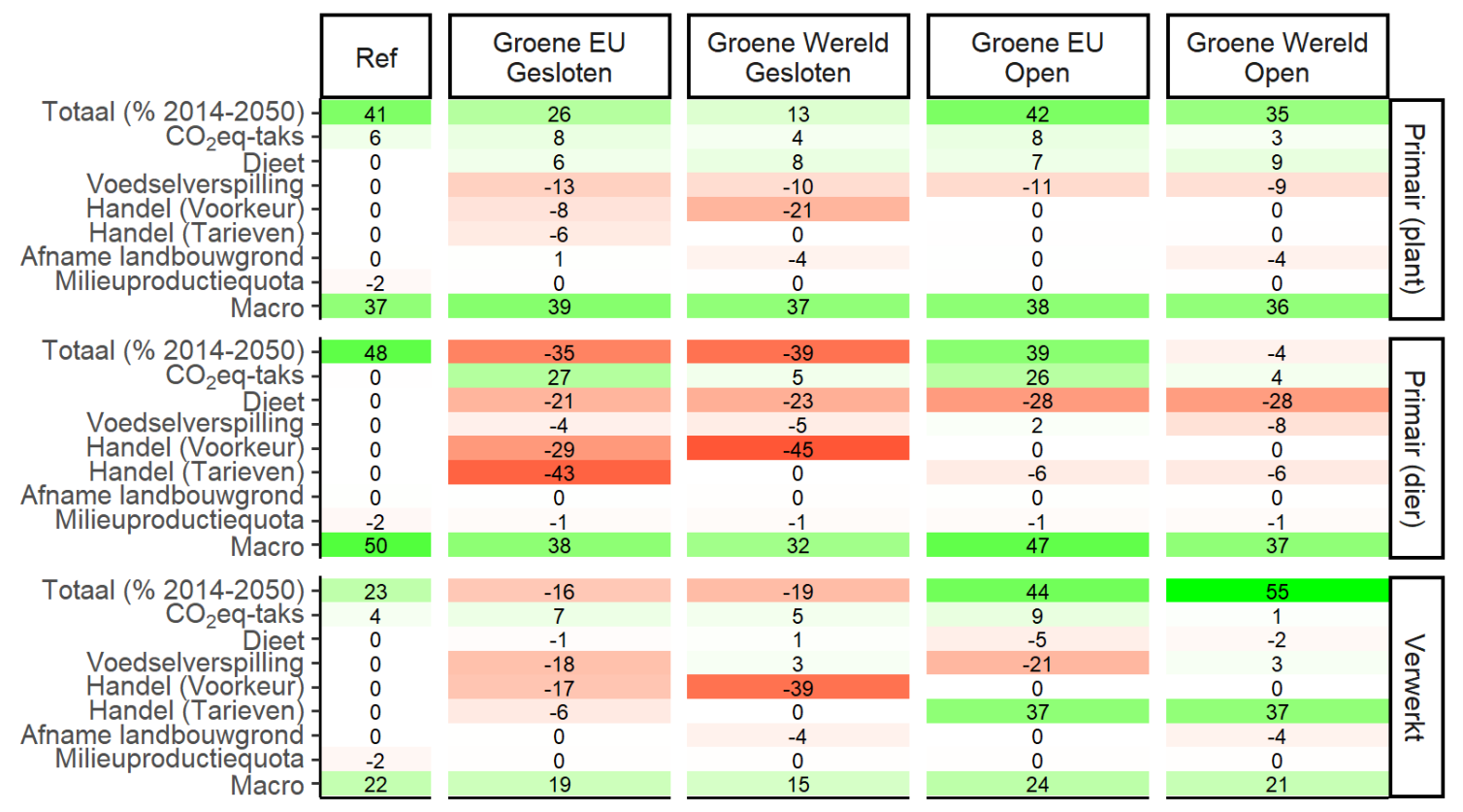

Figuur B1.23 Decompositie van importverandering (2014-2050), Nederland van Wereld buiten EU

\section{B1.3.6.2 Handel Nederland naar/van verschillende regio's}

Figuur B1.24 toont export- en importvolumes (primair totaal + verwerkt) voor 2014 en voor 2050 voor de scenario uitkomsten, voor Nederland naar alle regio's zoals geïmplementeerd in het MAGNET. 


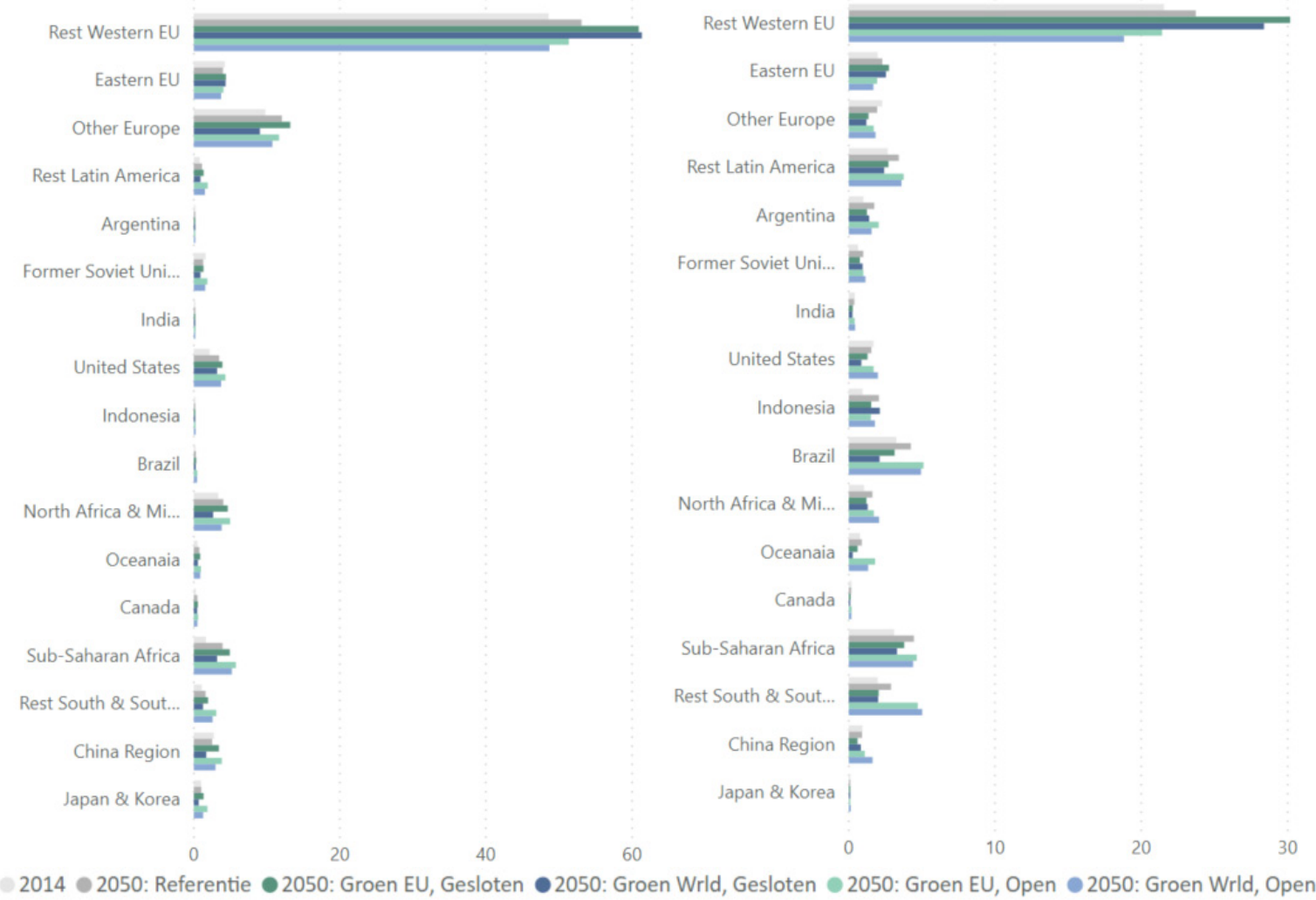

Figuur B1.24 Export- en importvolumes Nederland, per exportregio (Totaal Verwerkt + Primair)

\section{B1.3.6.3 Zelfvoorzieningsgraad}

Uit Figuur B1.25 is duidelijk dat hoewel voor de primaire sector de zelfvoorzieningsgraad zal dalen, dit effect al sterk aanwezig is in het referentiebeeld vanwege verhoogde import ten behoeve van een stijgende verwerkende industrie. In de scenario's verschuift dat beeld nauwelijks. In het Groene EU Gesloten-scenario, met beschermende importtarieven, is zelfs een lichte stijging in de zelfvoorzieningsgraad te zien.
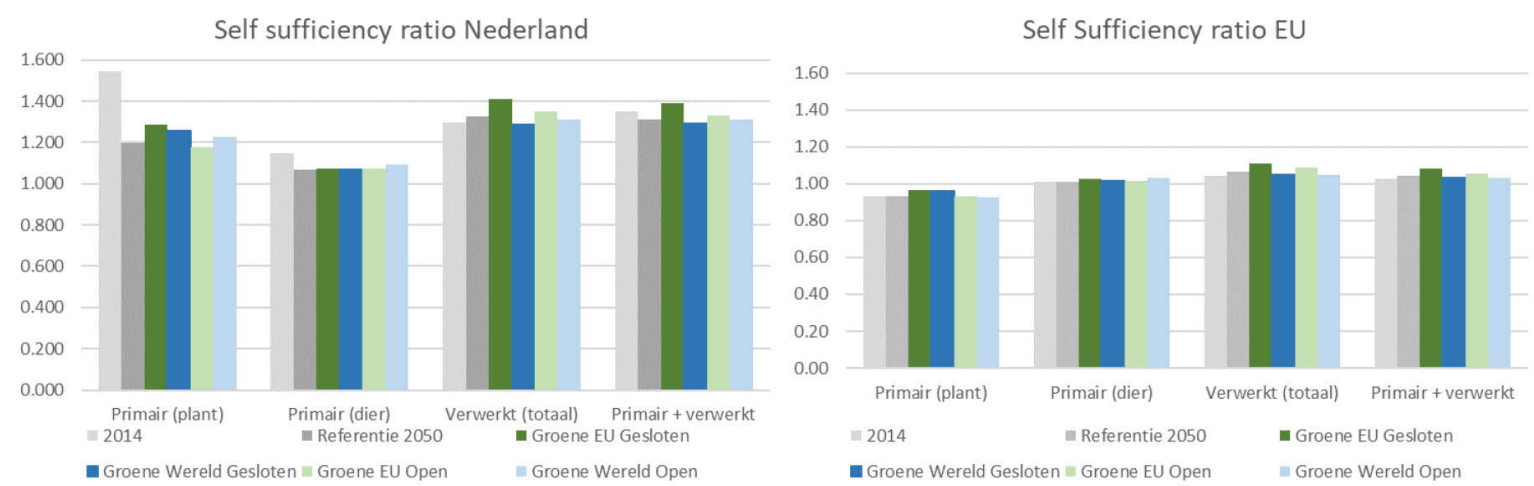

Figuur B1.25 Zelfvoorzieningsgraad Nederland en EU

\section{B1.3.7 BBP en toegevoegde waarde}

Figuur B1.26 laat het effect op het totale BBP ten opzichte van de referentie-uitkomst in 2050 zien. Het effect op het totale BBP is redelijk beperkt. Het effect op toegevoegde waarde in de primaire sector is uiteraard significanter (zie volgende grafiek). De BBP-effecten van deze vergroening in de landbouwsectoren zijn beperkt. De totale BBP-groei van 77\% in de 2014-2050 periode wordt met 
name verklaard door macro-effecten (productiviteitsstijging en bevolkingsgroei). Het pakket aan aannames heeft een beperkt effect, zoals zichtbaar is in Figuur B1.26. De impact is 0,5\% tot bijna $1 \%$ negatief in de gesloten scenario's en het Groene EU Open-scenario. Het Groene Wereld Open-scenario heeft zelfs een klein positief effect op BBP, wat verassend is omdat dit toch behoorlijke vergroening inhoudt. Figuur B1.27 (de decompositieanalyse) toont dat het $\mathrm{CO}_{2}$-eq-takseffect negatief is ter grootte van $2 \%$ à $3 \%$ in de Groene EU-scenario's en ongeveer $1 \%$ indien de Groene Wereld-scenario's. Het negatieve effect bij eenzijdige vergroening door de EU is iets hoger bij de open wereld dan bij de gesloten wereld. De reductie van voedselverspilling heeft in alle scenario's een positief effect op het BBP van driekwart procent. Handelsliberalisatie draagt ongeveer een half procent bij aan het BBP. Preferentieveranderingen naar binnenlands geproduceerde producten hebben een positief effect $(0,3 \%)$ op het Nederlandse BBP indien dit alleen in de EU plaatsvindt maar is behoorlijk negatief $(-0,9)$ indien dit wereldwijd gebeurt en ook de Nederlandse exportmarkten raakt.

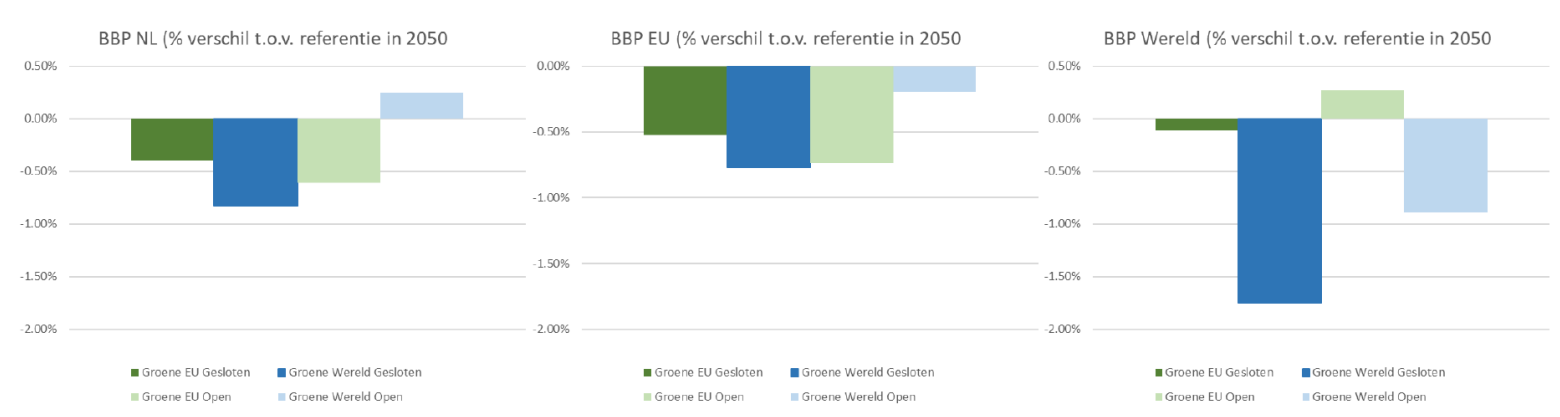

Figuur B1.26 BBP-verandering ten opzichte van referentie in 2050

\begin{tabular}{|c|c|c|c|c|c|}
\hline \multirow[b]{3}{*}{ Totaal (\% 2014-2050) } & \multicolumn{5}{|c|}{ Bijdrage (\% 2014-2050) op verandering BBP in NL } \\
\hline & Ref & $\begin{array}{c}\text { Groene EU } \\
\text { Gesloten }\end{array}$ & $\begin{array}{c}\text { Groene Wereld } \\
\text { Gesloten }\end{array}$ & $\begin{array}{l}\text { Groene EU } \\
\text { Open }\end{array}$ & $\begin{array}{c}\text { Groene Wereld } \\
\text { Open }\end{array}$ \\
\hline & 77.5 & 76.8 & 76 & 76.4 & 77.9 \\
\hline $\mathrm{CO}_{2}$ eq-taks & -0.3 & -2.3 & -1.3 & -2.9 & -1.3 \\
\hline Dieet & 0 & 0 & 0 & 0 & 0 \\
\hline Voedselverspilling & 0 & 0.8 & 0.8 & 0.8 & 0.7 \\
\hline Handel (Voorkeur) & 0 & 0.3 & -0.9 & 0 & 0 \\
\hline Handel (Tarieven) & 0 & 0.4 & 0 & 0.6 & 0.6 \\
\hline Afname landbouwgrond & 0 & 0 & 0 & 0 & 0 \\
\hline Milieuproductiequota & 0 & 0 & 0 & 0 & 0 \\
\hline Macro & 77.8 & 77.6 & 77.4 & 77.9 & 77.8 \\
\hline
\end{tabular}

Figuur B1.27 Decompositie van BBP-verandering (2014-2050), Nederland

Waar de toegevoegde waarde van de primaire sectoren daalt in de referentie (gelijke productie en dalende reële prijzen), stijgt die van de voedselverwerkende industrie met $40 \%$. Het belang van de verwerkende industrie neemt dus fors toe in het referentiescenario. De gesegmenteerde factormarkten voor land, arbeid en kapitaal tussen landbouw en niet landbouw sectoren (zie sectie 1.4) spelen hier ook een rol omdat in het referentiescenario de factor beloningen in de primaire landbouw achterblijven bij de rest van de economie, waartoe ook de verwerkende industrie behoort. De beloningen voor arbeid stijgen in de rest van de economie met ongeveer $50 \%-62 \%$ terwijl deze in de landbouw met 5\%-12\% stijgen (zie Tabel B1.4). De vraag naar land blijft relatief hoog zodat de grondprijzen met $25 \%$ stijgen. 

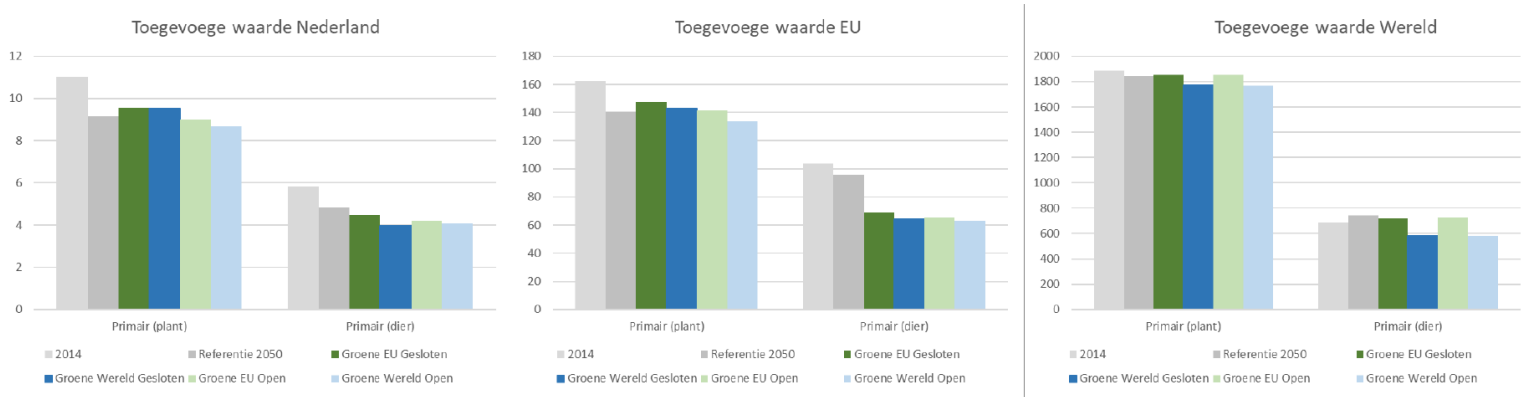

Figuur B1.28 Toegevoegde waarde (miljard USD)

Tabel B1.12 Toegevoegde waarde in miljard USD voor Europese regio's en rest van de Wereld (\% tussen haakjes is verschil ten opzichte van referentie in 2050)

\begin{tabular}{c|llllll} 
Region_agg2 & 2014 & $2050:$ Referentie & $2050:$ Groen EU, Gesloten & $2050:$ Groen Wrld, Gesloten & 2050: Groen EU, Open & 2050: Groen Wrid, Open \\
\hline 日 NL & 37.6 & 38.0 & $39.7(4.4 \%)$ & $36.8(-3.3 \%)$ & $38.3(0.8 \%)$ & $36.0(-5.3 \%)$ \\
Primair (plant) & 11.0 & 9.14 & $9.57(4.7 \%)$ & $9.55(4.5 \%)$ & $8.99(-1.6 \%)$ & $8.70(-4.8 \%)$ \\
Primair (dier) & 5.80 & 4.84 & $4.48(-7.4 \%)$ & $3.97(-18 \%)$ & $4.19(-13 \%)$ & $4.07(-16 \%)$ \\
Verwerkt & 20.7 & 24.0 & $25.6(6.7 \%)$ & $23.2(-3.2 \%)$ & $25.1(4.5 \%)$ & $23.2(-3.3 \%)$ \\
日 EU West & 441 & 433 & $423(-2.1 \%)$ & $403(-6.9 \%)$ & $412(-4.8 \%)$ & $390(-9.8 \%)$ \\
Primair (plant) & 127 & 110 & $117(5.8 \%)$ & $113(2.3 \%)$ & $112(1.4 \%)$ & $105(-5.2 \%)$ \\
Primair (dier) & 69.7 & 65.0 & $51.3(-21 \%)$ & $48.2(-26 \%)$ & $48.8(-25 \%)$ & $46.9(-28 \%)$ \\
Verwerkt & 245 & 257 & $255(-0.7 \%)$ & $242(-6.0 \%)$ & $251(-2.4 \%)$ & $239(-7.1 \%)$ \\
EU East & 91.5 & 83.7 & $80.2(-4.2 \%)$ & $76.9(-8.1 \%)$ & $79.3(-5.2 \%)$ & $75.9(-9.3 \%)$ \\
Primair (plant) & 24.7 & 21.0 & $21.0(0.2 \%)$ & $20.7(-1.5 \%)$ & $20.9(-0.4 \%)$ & $20.3(-3.2 \%)$ \\
Primair (dier) & 18.6 & 15.9 & $12.9(-19 \%)$ & $12.3(-22 \%)$ & $12.5(-21 \%)$ & $12.0(-24 \%)$ \\
Verwerkt & 48.2 & 46.8 & $46.3(-1.1 \%)$ & $43.9(-6.2 \%)$ & $45.9(-1.9 \%)$ & $43.6(-6.9 \%)$ \\
ROW & 3908 & 4497 & $4483(-0.3 \%)$ & $4206(-6.5 \%)$ & $4490(-0.1 \%)$ & $4181(-7.0 \%)$ \\
Primair (plant) & 1721 & 1702 & $1707(0.3 \%)$ & $1630(-4.3 \%)$ & $1713(0.6 \%)$ & $1633(-4.1 \%)$ \\
Primair (dier) & 596 & 659 & $654(-0.7 \%)$ & $514(-22 \%)$ & $662(0.3 \%)$ & $517(-22 \%)$
\end{tabular}

\section{B1.3.8 Werkgelegenheid}

Figuur B1.29 toont de ontwikkeling van werkgelegenheid (voor de agrifoodsector evenals geaggregeerde Services, Industrie en Energie sectoren) voor 2014 en voor 2050 voor de scenario uitkomsten, voor Nederland, EU, en Wereldwijd. In alle scenario's wordt de al aanwezige geprojecteerde daling van werkgelegenheid in de primaire sector versterkt.

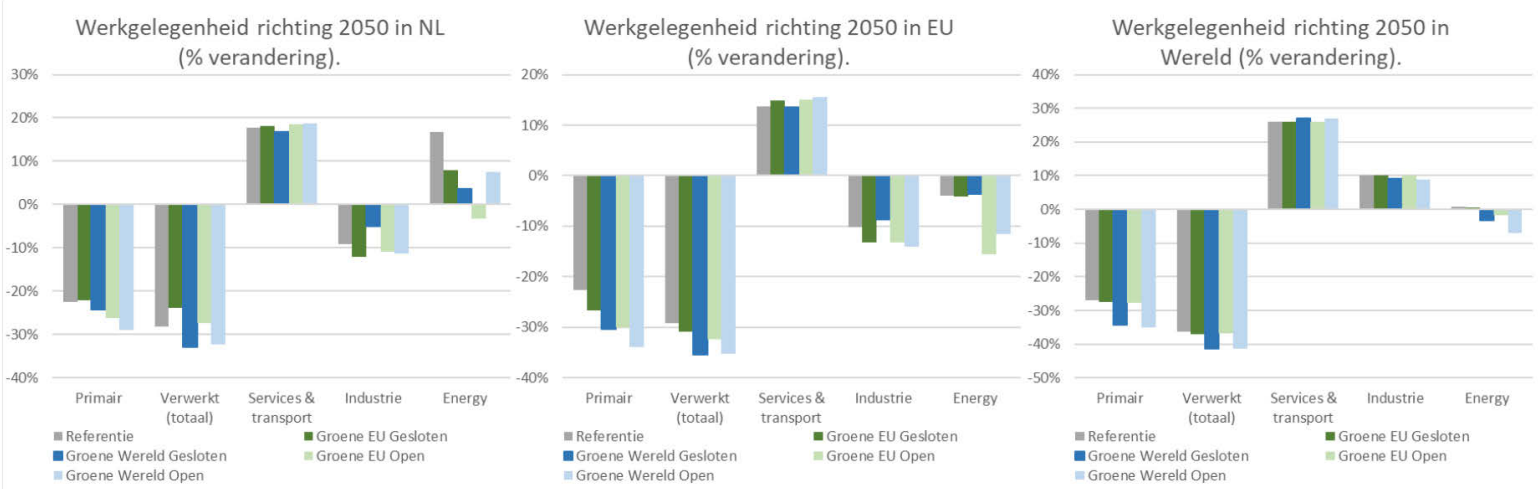

Figuur B1.29 Werkgelegenheid landbouw en overige economische sectoren 
Tabel B1.13 Werkgelegenheid voor Europese regio's en rest van de Wereld (\% tussen haakjes is verschil ten opzichte van referentie in 2050)

\begin{tabular}{|c|c|c|c|c|c|c|c|}
\hline \multicolumn{2}{|c|}{ Region_agg2 } & 2014 & \multirow{2}{*}{$\begin{array}{l}\text { 2050: Referentie } \\
\mathbf{7 . 8 3}\end{array}$} & \multirow{2}{*}{$\begin{array}{l}\text { 2050: Groen EU. Gesloten } \\
\mathbf{7 . 9 9}(\mathbf{2 \% )}\end{array}$} & \multirow{2}{*}{$\begin{array}{l}\text { 2050: Groen Wrid, Gesloten } \\
\mathbf{7 . 5 5}(-\mathbf{4} \%)\end{array}$} & \multirow{2}{*}{$\begin{array}{l}\text { 2050: Groen EU, Open } \\
\mathbf{7 . 5 9}(\mathbf{- 3 \% )}\end{array}$} & \multirow{2}{*}{$\begin{array}{l}\text { 2050: Groen Wrld, Open } \\
\mathbf{7 . 2 4}(\mathbf{- 8} \%)\end{array}$} \\
\hline$\boxminus$ & NL & 10.3 & & & & & \\
\hline & Primair (plant) & 5.01 & 3.92 & $4.07(4 \%)$ & $4.11(5 \%)$ & $3.89(-1 \%)$ & $3.74(-5 \%)$ \\
\hline & Primair (dier) & 2.15 & 1.64 & $1.51(-8 \%)$ & $1.31(-20 \%)$ & $1.40(-15 \%)$ & $1.35(-17 \%)$ \\
\hline & Verwerkt & 3.17 & 2.28 & $2.41(6 \%)$ & $2.13(-7 \%)$ & $2.30(1 \%)$ & $2.15(-6 \%)$ \\
\hline 曰 & EU West & 186 & 145 & $139(-4 \%)$ & $132(-9 \%)$ & $134(-7 \%)$ & $128(-12 \%)$ \\
\hline & Primair (plant) & 65.2 & 50.8 & $53.7(6 \%)$ & $51.6(2 \%)$ & $51.3(1 \%)$ & $47.9(-6 \%)$ \\
\hline & Primair (dier) & 37.8 & 31.3 & $24.5(-22 \%)$ & $23.1(-26 \%)$ & $23.4(-25 \%)$ & $22.6(-28 \%)$ \\
\hline & Verwerkt & 83.4 & 62.6 & $61.0(-3 \%)$ & $57.2(-9 \%)$ & $59.7(-5 \%)$ & $57.2(-9 \%)$ \\
\hline$\boxminus$ & EU East & 32.4 & 18.4 & $17.0(-8 \%)$ & $16.3(-12 \%)$ & $16.7(-10 \%)$ & $16.0(-13 \%)$ \\
\hline & Primair (plant) & 11.6 & 7.86 & $7.83(0 \%)$ & $7.55(-4 \%)$ & $7.73(-2 \%)$ & $7.42(-6 \%)$ \\
\hline & Primair (dier) & 9.61 & 6.28 & $5.06(-19 \%)$ & $4.89(-22 \%)$ & $4.92(-22 \%)$ & $4.77(-24 \%)$ \\
\hline & Verwerkt & 11.2 & 4.29 & $4.09(-5 \%)$ & $3.83(-11 \%)$ & $4.01(-7 \%)$ & $3.84(-11 \%)$ \\
\hline$\boxminus$ & ROW & 1801 & 1241 & $1236(0 \%)$ & $1127(-9 \%)$ & $1241(0 \%)$ & $1122(-10 \%)$ \\
\hline & Primair (plant) & 838 & 594 & $595(0 \%)$ & $567(-5 \%)$ & $595(0 \%)$ & $561(-6 \%)$ \\
\hline & Primair (dier) & 283 & 220 & $219(-1 \%)$ & $168(-24 \%)$ & $220(0 \%)$ & $167(-24 \%)$ \\
\hline & Verwerkt & 680 & 426 & $422(-1 \%)$ & $392(-8 \%)$ & $426(0 \%)$ & $394(-8 \%)$ \\
\hline & Total & 2030 & 1412 & $1400(-1 \%)$ & $1283(-9 \%)$ & $1400(-1 \%)$ & $1273(-10 \%)$ \\
\hline
\end{tabular}

\section{B1.3.9 Europese en wereldwijde effecten}
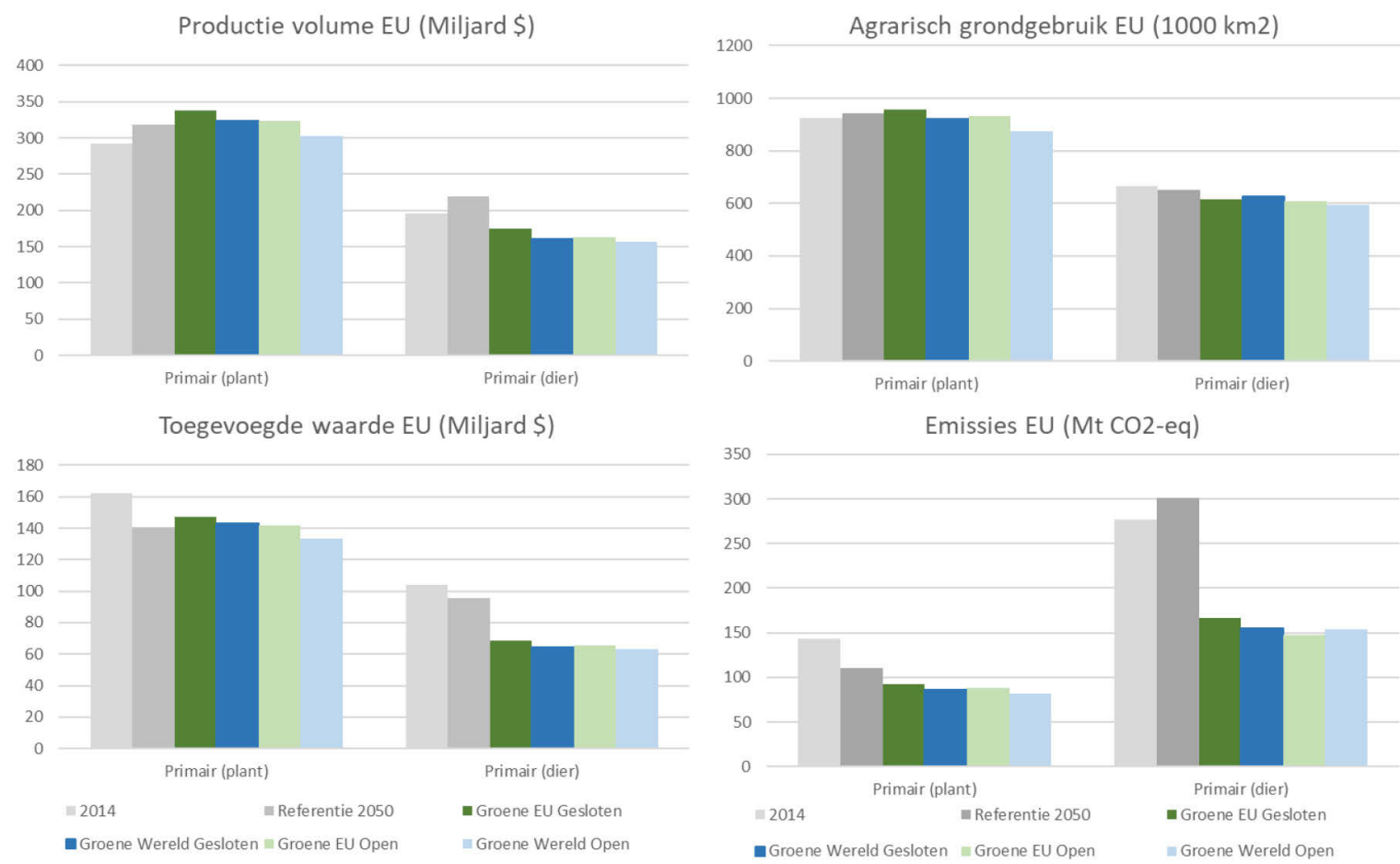

Figuur B1.30 Kernvariabelen EU

Hoewel de EU-situatie lijkt op de Nederlandse, zijn er enkele opvallende verschillen. Terwijl door huidig milieubeleid de dierlijke sectoren in Nederland constant blijven in het referentiescenario, blijven deze in de EU verder stijgen. De emissies gekoppeld aan de dierlijke sectoren blijven in de EU in het referentiescenario daarom ook stijgen. De vier vergroeningsscenario's hebben, ten opzichte van de referentie 2050, een grotere negatieve impact in de EU dan in Nederland. Productiedaling is $-20 \%$ in gesloten EU-scenario en $-27 \%$ tot $-29 \%$ in de overige scenario's, terwijl dit voor Nederland respectievelijk $-6 \%$ en $-18 \%$ tot $-23 \%$ was. Hierbij moet wel opgemerkt worden dat in de referentie de dierlijke productie in de EU wel nog stijgt met 12\% in de periode 2014-2050, waar deze in Nederland niet stijgt vanwege het milieuproductiequota. Voor de Europese dierlijke productie is de dieetverandering de grootste factor $(-17 \%$ tot $-21 \%$, zie Figuur B1.31) en vergelijkbaar met Nederland. De invloed van de $\mathrm{CO}_{2}$-eq-taks is minder negatief in de EU ten opzichte van Nederland mede doordat de EU in haar geheel 
meer gericht is op binnenlandse vraag en minder op de meer concurrerende exportmarkten zoals Nederland.

De emissies gelinkt aan dierlijke productie dalen met $48 \%$ in het gesloten EU-scenario en $52 \%-55 \%$ in de overige scenario's terwijl dit voor Nederland respectievelijk $30 \%$ en $39 \%-41 \%$ was. Ten opzichte van de beginsituatie is de daling in Groene EU Gesloten-scenario in Nederland $40 \%$ terwijl in de EU de daling $44 \%$ is. Voor de overige drie scenario's is de daling vergelijkbaar ter grootte van $45 \%$. De effecten van de individuele vergroenings- en handelsaannames is vergelijkbaar met Nederland al zijn alle aan handel gerelateerde effecten wat minder sterk wat betreft impact op emissies. Zo is het effect van broeikasgastaks compenserende tarieven $7 \%$ voor de EU en $10 \%$ voor Nederland vanwege de grotere exportgerichtheid (zie Figuur B1.32).

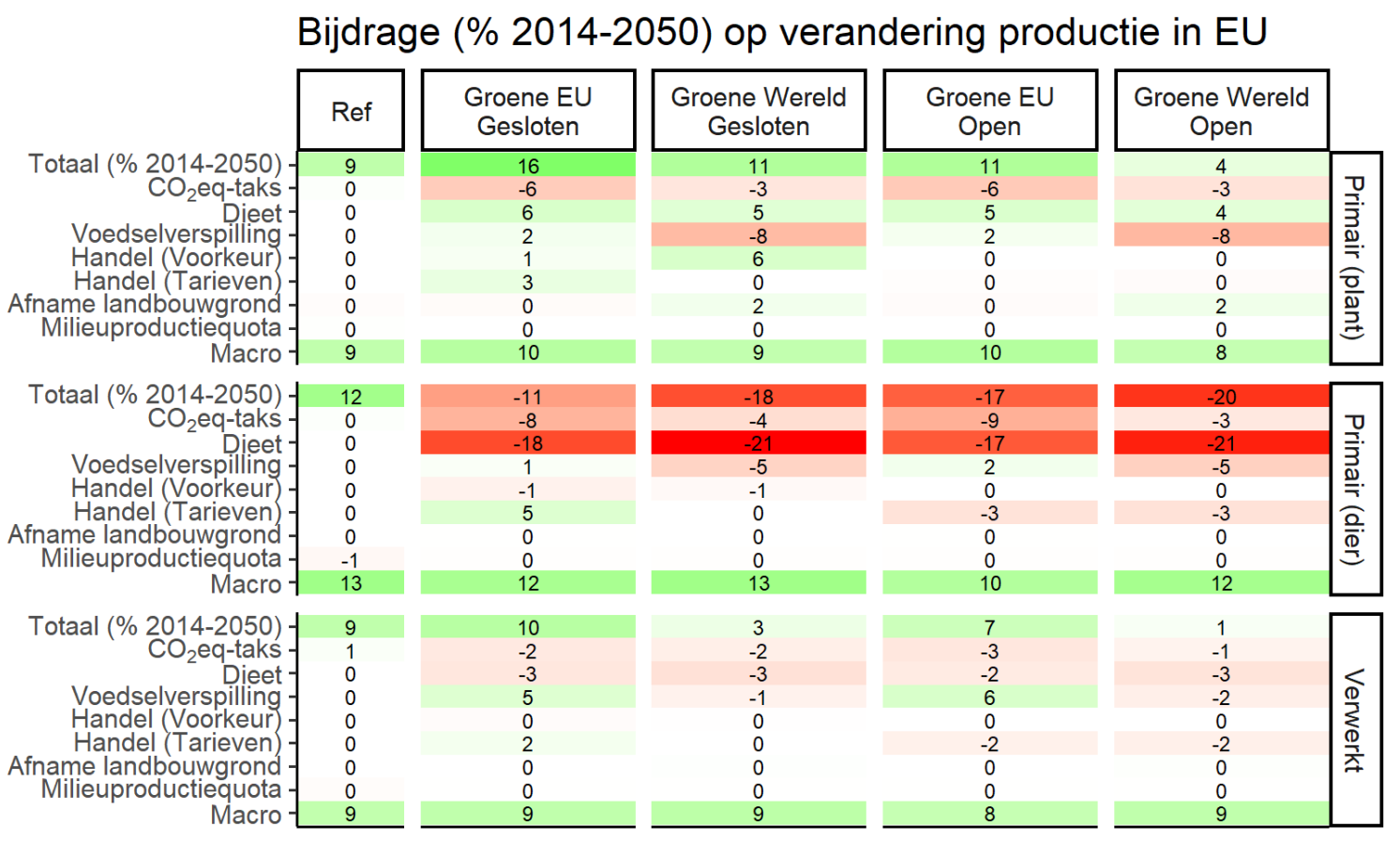

Figuur B1.31 Bijdrage scenarioaannames met betrekking tot verandering productie in de EU (\%)

\section{Bijdrage (\% 2014-2050) op verandering emissies in de EU}

\begin{tabular}{|c|c|c|c|c|c|c|}
\hline & Ref & $\begin{array}{l}\text { Groene EU } \\
\text { Gesloten }\end{array}$ & $\begin{array}{c}\text { Groene Wereld } \\
\text { Gesloten }\end{array}$ & $\begin{array}{l}\text { Groene EU } \\
\text { Open }\end{array}$ & $\begin{array}{c}\text { Groene Wereld } \\
\text { Open }\end{array}$ & \\
\hline $\begin{array}{r}\text { Totaal (\% 2014-2050) } \\
\mathrm{CO}_{2} \text { eq-taks } \\
\text { Djeet } \\
\text { Voedselverspilling } \\
\text { Handel (Voorkeur) } \\
\text { Handel (Tarieven) } \\
\text { Afname landbouwgrond } \\
\text { Milieuproductiequota } \\
\text { Macro }\end{array}$ & $\begin{array}{c}-23 \\
-2 \\
0 \\
0 \\
0 \\
0 \\
0 \\
0 \\
-21\end{array}$ & $\begin{array}{c}-35 \\
-17 \\
3 \\
-2 \\
1 \\
4 \\
0 \\
0 \\
-19\end{array}$ & $\begin{array}{c}-40 \\
-12 \\
2 \\
-10 \\
4 \\
0 \\
2 \\
0 \\
-20\end{array}$ & $\begin{array}{c}-39 \\
-17 \\
3 \\
-2 \\
0 \\
1 \\
0 \\
0 \\
-18\end{array}$ & $\begin{array}{c}-43 \\
-13 \\
2 \\
-10 \\
0 \\
1 \\
2 \\
0 \\
-19\end{array}$ & 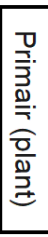 \\
\hline $\begin{array}{r}\text { Totaal (\% 2014-2050) } \\
\mathrm{CO}_{2} \text { eq-taks } \\
\text { Djeet } \\
\text { Voedselverspilling } \\
\text { Handel (Voorkeur) } \\
\text { Handel (Tarieven) } \\
\text { Afname landbouwgrond } \\
\text { Milieuproductiequota } \\
\text { Macro }\end{array}$ & $\begin{array}{c}8 \\
0 \\
0 \\
0 \\
0 \\
0 \\
0 \\
-1 \\
9\end{array}$ & $\begin{array}{c}-40 \\
-27 \\
-16 \\
0 \\
-1 \\
7 \\
0 \\
0 \\
7\end{array}$ & $\begin{array}{l}-44 \\
-18 \\
-18 \\
-5 \\
-1 \\
0 \\
0 \\
0 \\
8\end{array}$ & $\begin{array}{c}-47 \\
-26 \\
-15 \\
1 \\
0 \\
-4 \\
0 \\
0 \\
6\end{array}$ & $\begin{array}{c}-45 \\
-16 \\
-18 \\
-5 \\
0 \\
-3 \\
0 \\
0 \\
8\end{array}$ & 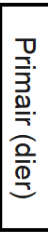 \\
\hline $\begin{array}{r}\text { Totaal (\% 2014-2050) } \\
\mathrm{CO}_{2} \text { eq-taks } \\
\text { Dijeet } \\
\text { Voedselverspilling } \\
\text { Handel (Voorkeur) } \\
\text { Handel (Tarieven) } \\
\text { Afname landbouwgrond } \\
\text { Milieuproductiequota } \\
\text { Macro }\end{array}$ & $\begin{array}{c}-7 \\
0 \\
0 \\
0 \\
0 \\
0 \\
0 \\
0 \\
-7\end{array}$ & $\begin{array}{l}-6 \\
-2 \\
2 \\
0 \\
0 \\
1 \\
0 \\
0 \\
-7\end{array}$ & $\begin{array}{c}-12 \\
-2 \\
2 \\
-5 \\
0 \\
0 \\
0 \\
0 \\
-6\end{array}$ & $\begin{array}{c}-6 \\
-3 \\
2 \\
1 \\
0 \\
1 \\
0 \\
0 \\
-7\end{array}$ & $\begin{array}{c}-10 \\
-2 \\
2 \\
-5 \\
0 \\
1 \\
0 \\
0 \\
-6\end{array}$ & 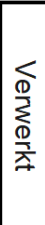 \\
\hline
\end{tabular}

Figuur B1.32 Bijdrage scenarioaannames met betrekking tot verandering emissies in de EU (\%) 

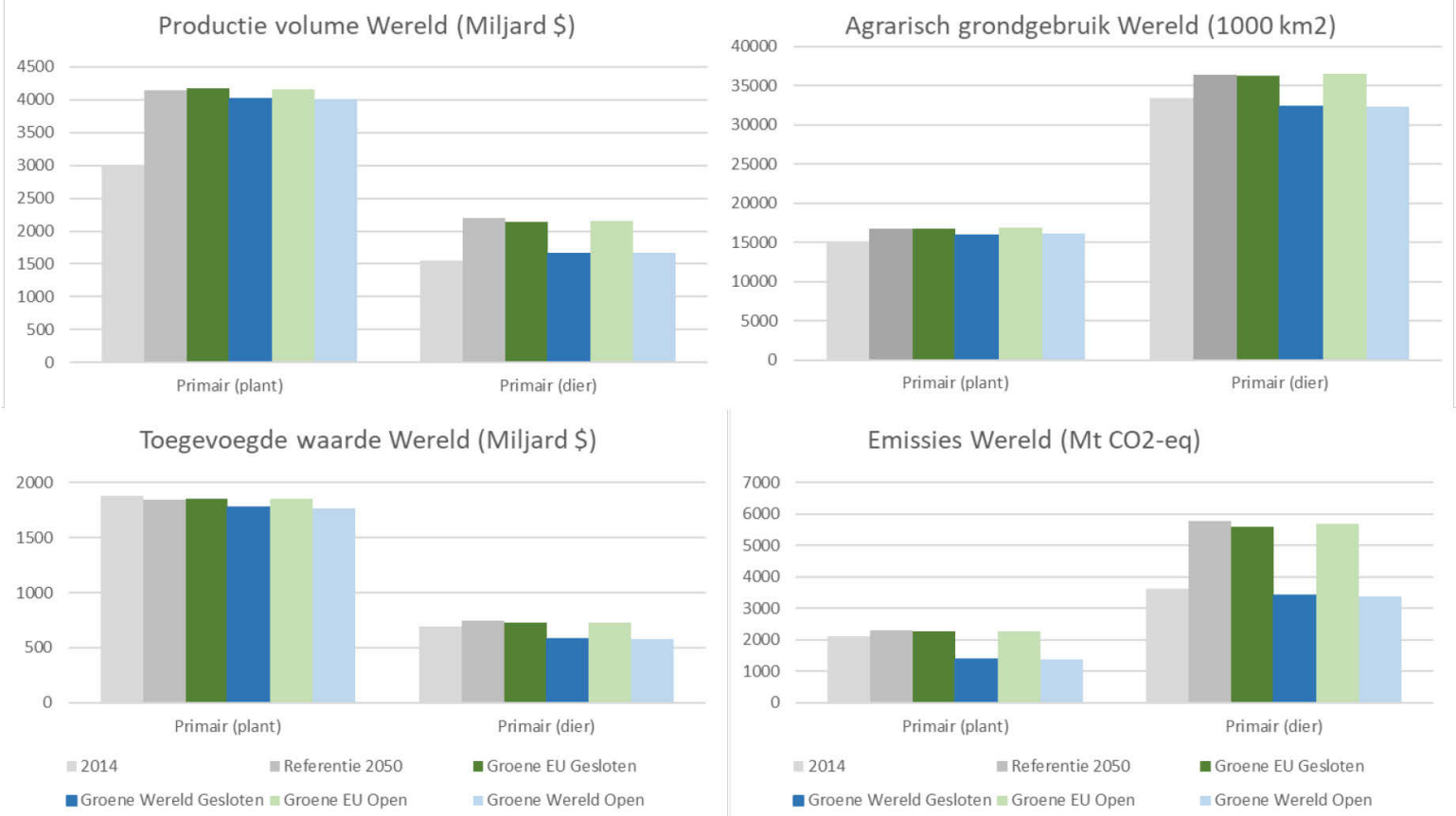

Figuur B1.33 Kernvariabelen Wereldwijd

Op wereldniveau is direct duidelijk dat de EU ondanks haar omvang een enigszins beperkte invloed heeft op het wereldresultaat. In de EU-scenario's worden productie, landgebruik en emissies op wereldniveau maar beperkt beïnvloed. Alleen dieet veranderingen in de EU hebben een beperkt negatieve $(-3 \%)$ invloed op de wereldwijde dierlijke productie en een beperkte positieve invloed op de plantaardige productie (1\%, zie Figuur B1.33). Reductie van voedselverspilling in de EU leidt tot een daling van $1 \%$ van zowel dierlijke als plantaardige productie op wereldniveau. Wereldwijde vergroeningsmaatregelen leiden daarentegen tot $25 \%$ minder dierlijke productie en $3 \%$ minder plantaardige productie en productie van verwerkte producten. Dieetverandering is bij dierlijke productie de grootste factor, gevolgd door $\mathrm{CO}_{2}$-eq-taks en reductie van voedselverspilling (Figuur B1.34).

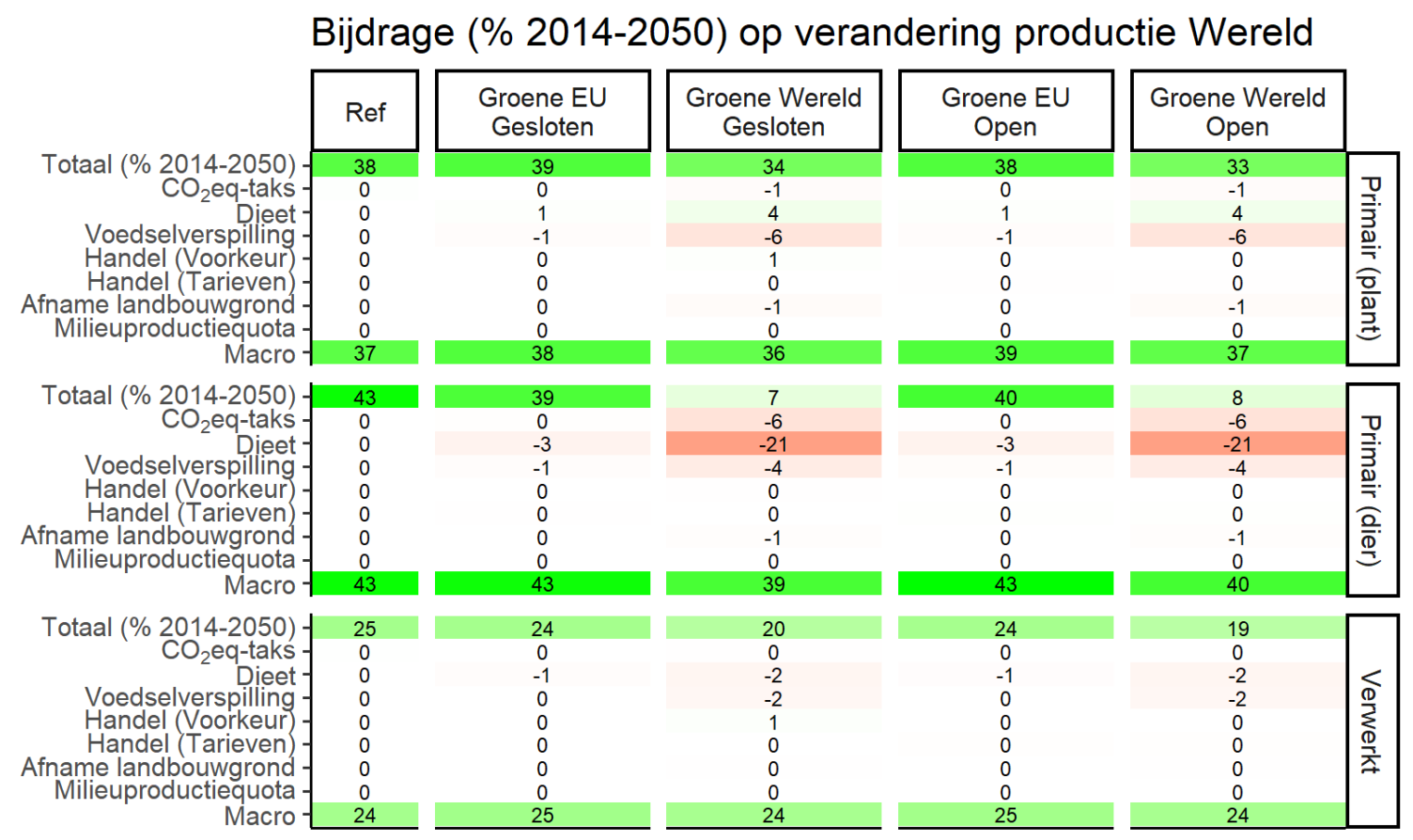

Figuur B1.34 Bijdrage scenarioaannames met betrekking tot verandering productie Wereldwijd (\%) 
Indien er enkel eenzijdige vergroening in de EU plaatsvindt dalen de wereldwijde emissies met $-1 \%$ a $-2 \%$ terwijl bij wereldwijde actie dit ongeveer $-40 \%$ is. De grootste drijvende kracht hierachter is de $\mathrm{CO}_{2}$-eq-taks, die een bijdrage levert van $-22 \%$ tot $-24 \%$ voor dierlijke sectoren en $-17 \%$ voor plantaardige sectoren. Dieetverandering leidt tot een extra daling van $14 \%$ van emissies uit dierlijke sectoren en de reductie van voedselverspilling bespaart $6 \%$ à $7 \%$ aan emissies op zowel plantaardige als dierlijke emissies. De handelseffecten zijn verwaarloosbaar op wereldniveau vanwege het beperkte effect hiervan op van de totale vraag op wereldniveau.

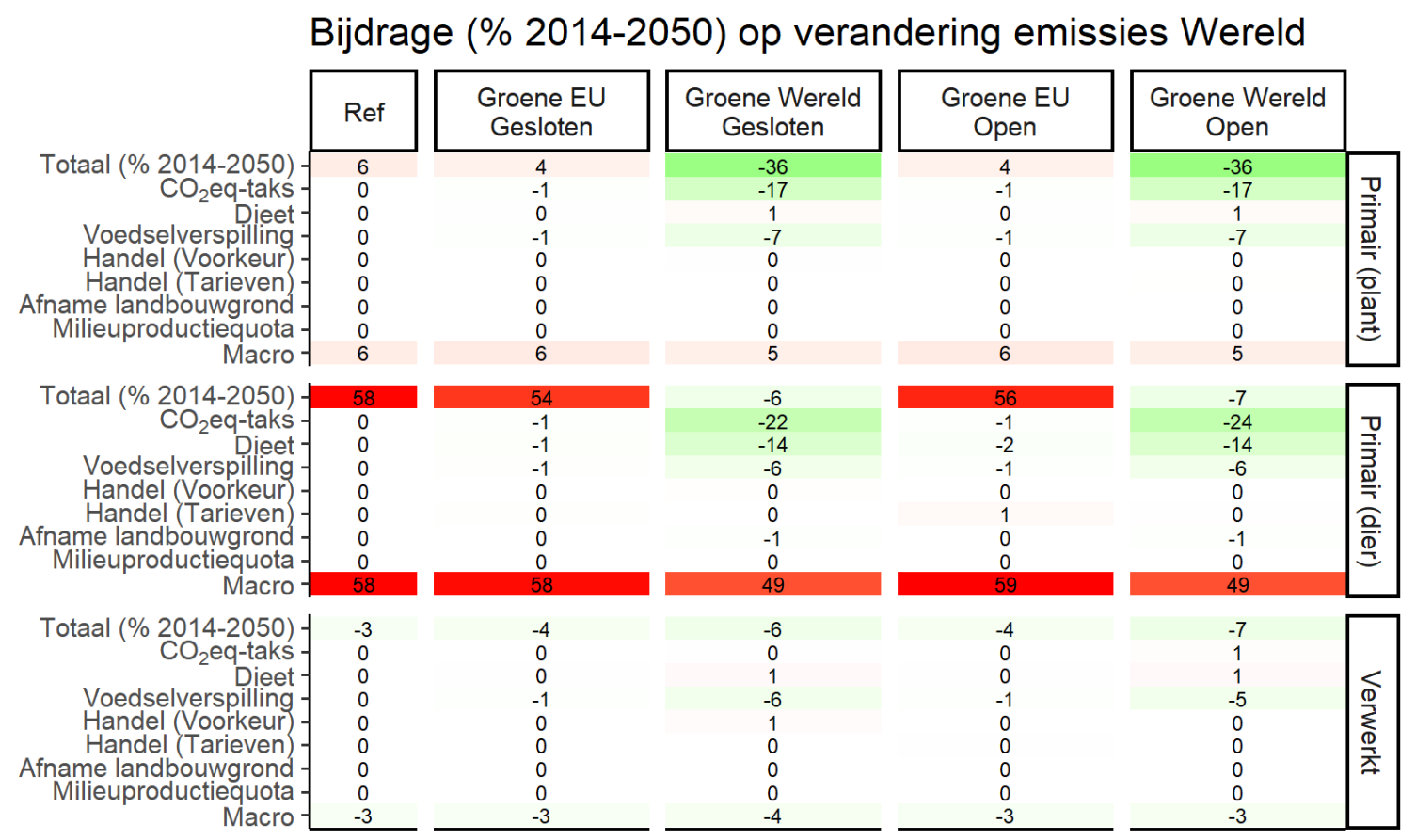

Figuur B1.35 Bijdrage scenarioaannames met betrekking tot verandering emissies Wereldwijd (\%). 


\section{Bijlage 2 Extra tabellen}

Tabel B2.1 Importtarieven voor wereldregio buiten Europa naar Nederland en EU gemiddeld

\begin{tabular}{llrrrrr}
$\begin{array}{l}\text { Importtarieven, 2050, } \\
\%\end{array}$ & RLE & 1,32 & $\begin{array}{r}\text { Groene EU } \\
\text { Gesloten }\end{array}$ & $\begin{array}{r}\text { Groene Wereld } \\
\text { Gesloten }\end{array}$ & $\begin{array}{r}\text { Groene EU } \\
\text { Open }\end{array}$ & $\begin{array}{r}\text { Groene Wereld } \\
\text { Open }\end{array}$ \\
\hline Primair (plant) & NLE & 10,45 & 1,23 & 0,19 & 0,22 \\
\hline Primair (plant) & EU & 1,88 & 11,5 & 1,78 & 0,29 & 0,32 \\
\hline Primair (dier) & NLE & 1,24 & 14,23 & 1,11 & 0,17 & 0,16 \\
\hline Primair (dier) & EU & 2,05 & 9,6 & 2,02 & 0,27 & 0,28 \\
\hline Verwerkt (totaal) & NLE & 9,43 & 11,95 & 6,09 & 2,26 & 2,06 \\
\hline Verwerkt (totaal) & EU & 7,31 & 10,36 & 5,25 & 2,11 & 1,74 \\
\hline Verwerkt (vlees) & NLE & 36,73 & 54,33 & 31,63 & 6,28 & 6,09 \\
\hline Verwerkt (vlees) & EU & 29,93 & 48,32 & 22,37 & 6,17 & 5,85 \\
\hline
\end{tabular}

\begin{tabular}{llrrrrr}
$\begin{array}{l}\text { Exportsubsidies, 2050, } \\
\text { \% }\end{array}$ & Referentie & $\begin{array}{r}\text { Groene EU } \\
\text { Gesloten }\end{array}$ & $\begin{array}{r}\text { Groene Wereld } \\
\text { Gesloten }\end{array}$ & $\begin{array}{r}\text { Groene EU } \\
\text { Open }\end{array}$ & $\begin{array}{r}\text { Groene Wereld } \\
\text { Open }\end{array}$ \\
\hline Primair (plant) & NLE & 0,00 & $-8,67$ & 0,00 & 0,00 & 0,00 \\
\hline Primair (plant) & EU & 0,00 & $-9,07$ & 0,00 & 0,00 & 0,00 \\
\hline Primair (dier) & NLE & $-0,07$ & $-23,31$ & $-0,05$ & $-0,01$ & $-0,01$ \\
\hline Primair (dier) & EU & 0,04 & $-20,63$ & 0,04 & 0,00 & 0,00 \\
\hline Verwerkt (totaal) & NLE & 0,00 & $-4,78$ & 0,00 & 0,00 & 0,00 \\
\hline Verwerkt (totaal) & EU & 0,00 & $-3,95$ & 0,00 & 0,00 & 0,00 \\
\hline Verwerkt (vlees) & NLE & 0,00 & $-10,07$ & 0,00 & 0,00 & 0,00 \\
\hline Verwerkt (vlees) & EU & 0,00 & $-8,66$ & 0,00 & 0,00 & 0,00 \\
\hline
\end{tabular}

* Waarde is het $\%$ van de totale prijs wat importtarief is, Dus $20 \%$ betekent dat import tarief $20 \%$ van de prijs

Tabel B2.2 Uitkomsten hoofdindicator voor Nederland (\% verandering ten opzichte van referentie in 2050)

\begin{tabular}{|c|c|c|c|c|c|c|c|}
\hline Vari & riable (unit) & 2014 & 2050: Referentie & 2050: Groen EU, Gesloten & 2050: Groen Wrld, Gesloten & 2050: Groen EU, Open & 2050: Groen Wrild. Open \\
\hline$\boxminus$ & Production Volume (Miljard \$) & & & & & & \\
\hline & Primair (plant) & 25.1 & 24.9 & $26.8(8 \%)$ & $26.6(7 \%)$ & $25.1(1 \%)$ & $24.2(-3 \%)$ \\
\hline & Primair (dier) & 15.3 & 15.3 & $14.3(-6 \%)$ & $12.0(-22 \%)$ & $12.6(-18 \%)$ & $11.7(-23 \%)$ \\
\hline & Verwerkt & 105 & 122 & $134(10 \%)$ & $120(-2 \%)$ & $128(5 \%)$ & $117(-4 \%)$ \\
\hline 日 & Demand (Miljard \$) & & & & & & \\
\hline & Primair (plant) & 13.8 & 13.9 & $15.8(14 \%)$ & $12.4(-11 \%)$ & $13.7(-1 \%)$ & $12.1(-13 \%)$ \\
\hline & Primair (dier) & 12.8 & 12.5 & $12.6(0 \%)$ & $9.20(-27 \%)$ & $10.0(-20 \%)$ & $9.14(-27 \%)$ \\
\hline & Verwerkt & 52.6 & 54.6 & $54.9(0 \%)$ & $44.4(-19 \%)$ & $50.3(-8 \%)$ & $46.8(-14 \%)$ \\
\hline 曰 & Export Volume (Miljard \$) & & & & & & \\
\hline & Primair (plant) & 21.5 & 21.2 & $23.2(9 \%)$ & $23.0(8 \%)$ & $21.5(1 \%)$ & $20.7(-2 \%)$ \\
\hline & Primair (dier) & 3.33 & 2.74 & $2.60(-5 \%)$ & $2.01(-27 \%)$ & $2.06(-25 \%)$ & $2.02(-26 \%)$ \\
\hline & Verwerkt & 52.5 & 64.9 & $76.4(18 \%)$ & $64.4(-1 \%)$ & $72.5(12 \%)$ & $64.2(-1 \%)$ \\
\hline 曰 & Import Volume (Miljard \$) & & & & & & \\
\hline & Primair (plant) & 12.8 & 16.5 & $17.6(7 \%)$ & $16.2(-2 \%)$ & $16.7(2 \%)$ & $15.4(-6 \%)$ \\
\hline & Primair (dier) & 1.38 & 1.87 & $1.71(-8 \%)$ & $1.41(-25 \%)$ & $1.30(-31 \%)$ & $1.10(-41 \%)$ \\
\hline & Verwerkt & 29.6 & 34.1 & $33.4(-2 \%)$ & $31.7(-7 \%)$ & $36.0(5 \%)$ & $35.3(3 \%)$ \\
\hline$\boxminus$ & Production Prices (Index) & & & & & & \\
\hline & Primair (plant) & 1.00 & 0.80 & $0.84(5 \%)$ & $0.81(1 \%)$ & $0.78(-3 \%)$ & $0.75(-7 \%)$ \\
\hline & Primair (dier) & 1.00 & 0.93 & $0.94(1 \%)$ & $0.93(0 \%)$ & $0.89(-4 \%)$ & $0.87(-6 \%)$ \\
\hline & Verwerkt & 1.00 & 0.94 & $0.89(-6 \%)$ & $0.88(-7 \%)$ & $0.87(-8 \%)$ & $0.85(-10 \%)$ \\
\hline 日 & Consumer prices (Index) & & & & & & \\
\hline & Primair (plant) & 1.00 & 0.79 & $0.84(6 \%)$ & $0.73(-8 \%)$ & $0.77(-3 \%)$ & $0.75(-6 \%)$ \\
\hline & Primair (dier) & 1.00 & 0.93 & $0.93(1 \%)$ & $0.80(-14 \%)$ & $0.87(-7 \%)$ & $0.84(-10 \%)$ \\
\hline & Verwerkt & 1.00 & 0.96 & $0.96(0 \%)$ & $0.85(-12 \%)$ & $0.89(-8 \%)$ & $0.88(-8 \%)$ \\
\hline
\end{tabular}




\begin{tabular}{|c|c|c|c|c|c|c|}
\hline Variable (unit) & 2014 & 4 2050: Referentie & 2050: Groen EU, Gesloten & 2050: Groen Wrid. Gesloten & 2050: Groen EU, Open & 2050: Groen Wrild. Open \\
\hline Primair (plant) & 8.38 & 8.04 & $7.78(-3.1 \%)$ & $7.44(-7.4 \%)$ & $7.61(-5.3 \%)$ & $7.18(-11 \%)$ \\
\hline \multicolumn{7}{|l|}{ Verwerkt } \\
\hline \multicolumn{7}{|l|}{$\boxminus$ Value added (Miljard \$) } \\
\hline Primair (plant) & 10.1 & 8.75 & $9.06(3.6 \%)$ & $8.46(-3.2 \%)$ & $7.91(-9.6 \%)$ & $7.13(-19 \%)$ \\
\hline \multicolumn{7}{|l|}{$\boxminus$ Employment (Miljard \$) } \\
\hline Primair (plant) & 5.01 & 3.92 & $4.07(3.8 \%)$ & $4.11(5.0 \%)$ & $3.89(-0.8 \%)$ & $3.74(-4.6 \%)$ \\
\hline Primair (dier) & 2.15 & 1.64 & $1.51(-7.9 \%)$ & $1.31(-20 \%)$ & $1.40(-15 \%)$ & $1.35(-17 \%)$ \\
\hline Verwerkt & 3.17 & 2.28 & $2.41(5.9 \%)$ & $2.13(-6.6 \%)$ & $2.30(1.0 \%)$ & $2.15(-5.7 \%)$ \\
\hline (1) GDP (Triljoen \$) & 0.88 & B 1.56 & $1.55(-0.4 \%)$ & $1.55(-0.8 \%)$ & $1.55(-0.6 \%)$ & $1.56(0.2 \%)$ \\
\hline$\boxminus$ Primair (plant) & 8.85 & 6.76 & $6.38(-5.7 \%)$ & $6.22(-8.0 \%)$ & $5.97(-12 \%)$ & $5.71(-16 \%)$ \\
\hline Carbon Dioxide & 3.19 & 2.43 & $2.50(2.9 \%)$ & $2.45(1.0 \%)$ & $2.37(-2.5 \%)$ & $2.27(-6.6 \%)$ \\
\hline Methane & 0.18 & 0.13 & $0.14(6.4 \%)$ & $0.14(6.2 \%)$ & $0.13(-3.0 \%)$ & $0.13(-4.3 \%)$ \\
\hline Nitrious Oxide & 5.48 & 4.20 & $3.74(-11 \%)$ & $3.63(-14 \%)$ & $3.47(-17 \%)$ & $3.31(-21 \%)$ \\
\hline$\boxminus$ Primair (dier) & 17.8 & 17.1 & $11.8(-31 \%)$ & $10.1(-41 \%)$ & $9.92(-42 \%)$ & $9.85(-42 \%)$ \\
\hline Carbon Dioxide & 2.43 & 1.86 & $1.68(-10 \%)$ & $1.28(-31 \%)$ & $1.35(-28 \%)$ & $1.11(-40 \%)$ \\
\hline Methane & 11.1 & 11.1 & $6.95(-37 \%)$ & $6.10(-45 \%)$ & $5.94(-46 \%)$ & $6.13(-45 \%)$ \\
\hline Nitrious Oxide & 4.27 & 4.19 & $3.17(-24 \%)$ & $2.69(-36 \%)$ & $2.63(-37 \%)$ & $2.60(-38 \%)$ \\
\hline Verwerkt & 3.09 & 3.26 & $3.45(6.1 \%)$ & $3.10(-4.8 \%)$ & $3.57(9.5 \%)$ & $3.27(0.6 \%)$ \\
\hline Carbon Dioxide & 3.08 & 3.25 & $3.45(6.1 \%)$ & $3.09(-4.8 \%)$ & $3.56(9.5 \%)$ & $3.27(0.6 \%)$ \\
\hline Methane & 0.00 & 0.00 & $0.00(5.8 \%)$ & $0.00(-5.0 \%)$ & $0.00(6.7 \%)$ & $0.00(-1.5 \%)$ \\
\hline
\end{tabular}

Tabel B2.3 Uitkomsten hoofdindicator voor de EU (\% verandering ten opzichte van referentie in 2050)

\begin{tabular}{|c|c|c|c|c|c|c|}
\hline Variable (unit) & 2014 & 2050: Referentie & 2050: Groen EU, Gesloten & 2050: Groen Wrld, Gesloten & 2050: Groen EU, Open & 2050: Groen Wrld, Open \\
\hline \multicolumn{7}{|c|}{$\boxminus$ Production Volume (Miljard \$) } \\
\hline † Primair (plant) & 292 & 318 & $338(6 \%)$ & $323(2 \%)$ & $324(2 \%)$ & $303(-5 \%)$ \\
\hline 田 Primair (dier) & 196 & 220 & $175(-20 \%)$ & $160(-27 \%)$ & $163(-26 \%)$ & $157(-29 \%)$ \\
\hline 凹 Verwerkt & 1327 & 1445 & $1458(1 \%)$ & $1363(-6 \%)$ & $1424(-1 \%)$ & $1341(-7 \%)$ \\
\hline \multicolumn{7}{|c|}{$\boxminus$ Demand (Miljard \$) } \\
\hline Ð Primair (plant) & 199 & 187 & $199(7 \%)$ & $157(-16 \%)$ & $179(-4 \%)$ & $160(-15 \%)$ \\
\hline 甲 Primair (dier) & 172 & 147 & $134(-9 \%)$ & $107(-27 \%)$ & $116(-21 \%)$ & $108(-27 \%)$ \\
\hline$\boxplus$ Verwerkt & 571 & 561 & $535(-5 \%)$ & $453(-19 \%)$ & $500(-11 \%)$ & $480(-14 \%)$ \\
\hline \multicolumn{7}{|c|}{$\boxminus$ Export Volume (Miljard \$) } \\
\hline Ð Primair (plant) & 96.7 & 100 & $117(16 \%)$ & $106(6 \%)$ & $105(4 \%)$ & $94.2(-6 \%)$ \\
\hline$\boxplus$ Primair (dier) & 23.4 & 26.3 & $27.0(3 \%)$ & $21.5(-18 \%)$ & $22.2(-16 \%)$ & $22.5(-14 \%)$ \\
\hline$\boxplus$ Verwerkt & 394 & 457 & $516(13 \%)$ & $427(-7 \%)$ & $500(9 \%)$ & $435(-5 \%)$ \\
\hline \multicolumn{7}{|c|}{$\boxminus$ Import Volume (Miljard \$) } \\
\hline$\Psi$ Primair (plant) & 125 & 140 & $143(2 \%)$ & $134(-4 \%)$ & $143(2 \%)$ & $137(-2 \%)$ \\
\hline$\boxplus$ Primair (dier) & 23.9 & 25.8 & $21.9(-15 \%)$ & $20.3(-21 \%)$ & $21.1(-18 \%)$ & $19.3(-25 \%)$ \\
\hline Ð Verwerkt & 355 & 384 & $370(-4 \%)$ & $363(-5 \%)$ & $398(4 \%)$ & $396(3 \%)$ \\
\hline \multicolumn{7}{|c|}{$\boxminus$ Private consumption (Miljard \$) } \\
\hline Ð Primair (plant) & 122 & 101 & $115(14 \%)$ & $98.2(-3 \%)$ & $106(4 \%)$ & $102(1 \%)$ \\
\hline 田 Primair (dier) & 23.7 & 23.3 & $17.0(-27 \%)$ & $14.7(-37 \%)$ & $16.3(-30 \%)$ & $15.8(-32 \%)$ \\
\hline Đ Verwerkt & 716 & 764 & $737(-4 \%)$ & $656(-14 \%)$ & $708(-7 \%)$ & $706(-8 \%)$ \\
\hline \multicolumn{7}{|c|}{$\square$ Production Prices (Index) } \\
\hline$\boxplus$ Primair (plant) & 1.00 & 0.79 & $0.80(2 \%)$ & $0.76(-4 \%)$ & $0.75(-5 \%)$ & $0.72(-9 \%)$ \\
\hline$\boxplus$ Primair (dier) & 1.00 & 0.76 & $0.83(10 \%)$ & $0.80(6 \%)$ & $0.78(3 \%)$ & $0.76(0 \%)$ \\
\hline Ð Verwerkt & 1.00 & 0.94 & $0.90(-5 \%)$ & $0.89(-5 \%)$ & $0.88(-7 \%)$ & $0.87(-8 \%)$ \\
\hline \multicolumn{7}{|c|}{$\boxminus$ Consumer prices (Index) } \\
\hline ๑ Primair (plant) & 1.00 & 0.80 & $0.84(4 \%)$ & $0.71(-12 \%)$ & $0.77(-5 \%)$ & $0.74(-8 \%)$ \\
\hline 甲 Primair (dier) & 1.00 & 0.76 & $0.81(7 \%)$ & $0.68(-10 \%)$ & $0.76(1 \%)$ & $0.73(-4 \%)$ \\
\hline Ð Verwerkt & 1.00 & 0.97 & $0.98(1 \%)$ & $0.86(-11 \%)$ & $0.93(-5 \%)$ & $0.93(-5 \%)$ \\
\hline \multicolumn{7}{|c|}{$\square$ Net export as \% of Production } \\
\hline Ð Primair (plant) & -9.35 & -11.4 & $-6.89(-40 \%)$ & $-8.97(-21 \%)$ & $-11.6(1 \%)$ & $-13.2(16 \%)$ \\
\hline$\boxplus$ Primair (dier) & -0.17 & 0.12 & $1.74(1404 \%)$ & $0.54(368 \%)$ & $0.69(500 \%)$ & $2.20(1804 \%)$ \\
\hline Ð Verwerkt & 3.45 & 5.61 & $9.37(67 \%)$ & $4.47(-20 \%)$ & $7.96(42 \%)$ & $4.52(-19 \%)$ \\
\hline
\end{tabular}


Tabel B2.4 Uitkomsten hoofdindicator Wereldwijd (\% verandering ten opzichte van referentie in 2050)

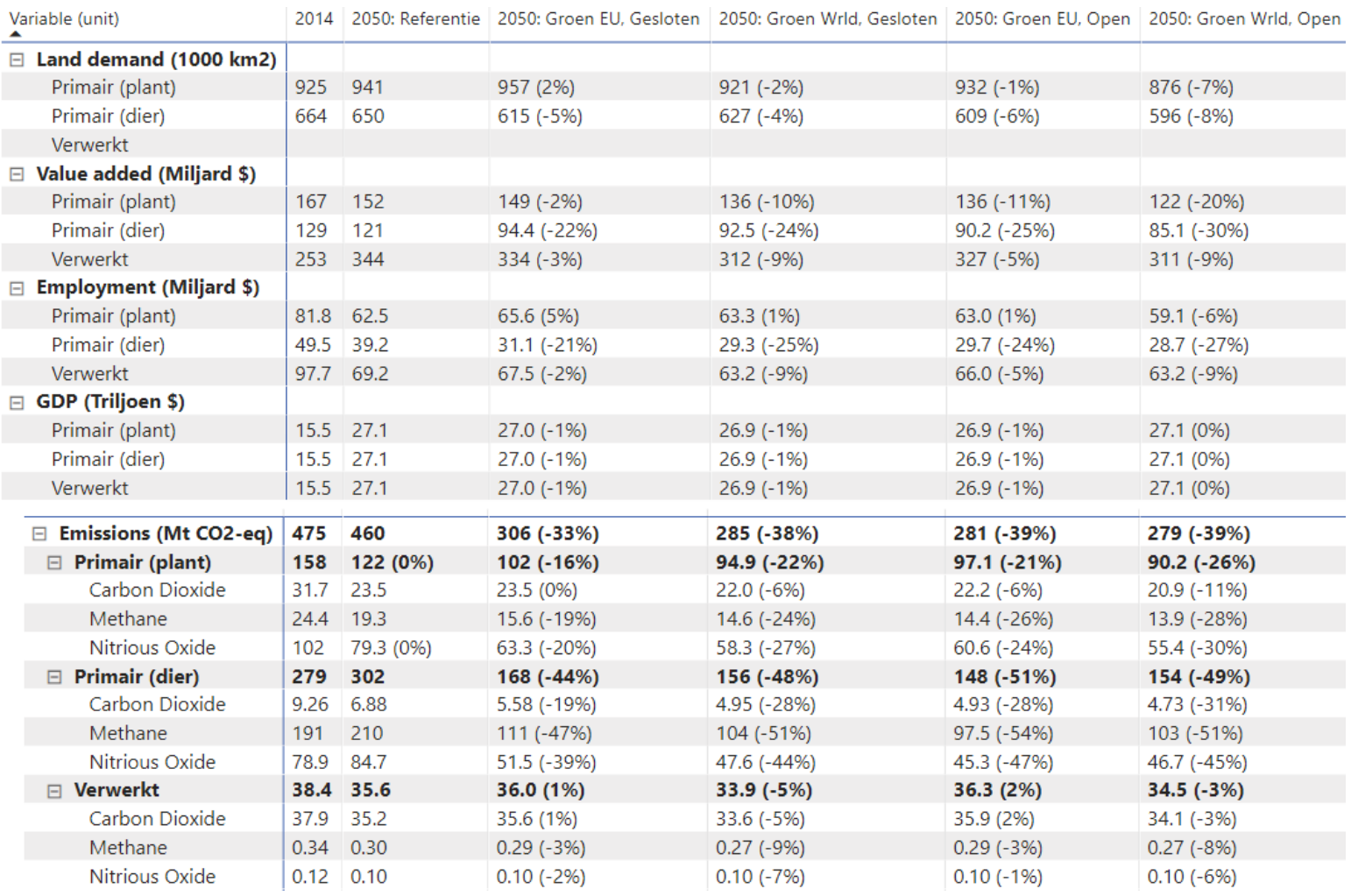

\begin{tabular}{|c|c|c|c|c|c|c|c|}
\hline \multicolumn{2}{|c|}{ Variable (unit) } & \multirow[t]{2}{*}{2014} & \multirow[t]{2}{*}{ 2050: Referentie } & \multirow[t]{2}{*}{ 2050: Groen EU, Gesloten } & \multirow[t]{2}{*}{ 2050: Groen Wrid, Gesloten } & \multirow[t]{2}{*}{ 2050: Groen EU. Open } & \multirow[t]{2}{*}{ 2050: Groen Wrld, Open } \\
\hline 日 & Production Volu & & & & & & \\
\hline & Primair (plant) & 3006 & 4135 & $4165(1 \%)$ & $4015(-3 \%)$ & $4162(1 \%)$ & $4005(-3 \%)$ \\
\hline & Primair (dier) & 1545 & 2205 & $2146(-3 \%)$ & $1658(-25 \%)$ & $2158(-2 \%)$ & $1674(-24 \%)$ \\
\hline \multicolumn{8}{|c|}{$\boxminus$ Demand (Miljard \$) } \\
\hline & Primair (plant) & 1990 & 2497 & $2511(1 \%)$ & $2161(-13 \%)$ & $2508(0 \%)$ & $2166(-13 \%)$ \\
\hline & Primair (dier) & 1126 & 1272 & $1233(-3 \%)$ & $1367(7 \%)$ & $1243(-2 \%)$ & $1380(8 \%)$ \\
\hline \multirow[t]{4}{*}{$\boxminus \mathbf{P}$} & Production Price & & & & & & \\
\hline & Primair (plant) & 1.00 & 0.88 & $0.88(0 \%)$ & $0.82(-7 \%)$ & $0.88(0 \%)$ & $0.82(-7 \%)$ \\
\hline & Primair (dier) & 1.00 & 0.81 & $0.81(0 \%)$ & $1.14(41 \%)$ & $0.81(0 \%)$ & $1.14(40 \%)$ \\
\hline & Verwerkt & 1.00 & 1.00 & $0.99(-1 \%)$ & $0.95(-5 \%)$ & $0.99(-1 \%)$ & $0.95(-5 \%)$ \\
\hline \multirow[t]{2}{*}{$\boxminus c$} & Consumer prices & & & & & & \\
\hline & Primair (plant) & 1.00 & 0.79 & $0.78(-1 \%)$ & $0.72(-9 \%)$ & $0.77(-2 \%)$ & $0.72(-9 \%)$ \\
\hline
\end{tabular}

\begin{tabular}{|c|c|c|c|c|c|c|c|}
\hline \multicolumn{2}{|c|}{ Variable (unit) } & \multirow[t]{2}{*}{2014} & \multirow[t]{2}{*}{ 2050: Referentie } & \multirow[t]{2}{*}{ 2050: Groen EU, Gesloten } & \multirow[t]{2}{*}{ 2050: Groen Wrid. Gesloten } & \multirow[t]{2}{*}{ 2050: Groen EU, Open } & \multirow[t]{2}{*}{ 2050: Groen Wrid. Open } \\
\hline 日 & Land demand (10 & & & & & & \\
\hline & Primair (plant) & 14823 & 16690 & $16773(0 \%)$ & $15909(-5 \%)$ & $16846(1 \%)$ & $16146(-3 \%)$ \\
\hline & Primair (dier) & 33397 & 36373 & $36248(0 \%)$ & $32274(-11 \%)$ & $36444(0 \%)$ & $32294(-11 \%)$ \\
\hline$\boxminus$ & Value added (Mil) & & & & & & \\
\hline & Primair (plant) & 1892 & 2636 & $2621(-1 \%)$ & $2007(-24 \%)$ & $2645(0 \%)$ & $2013(-24 \%)$ \\
\hline & Primair (dier) & 721 & 863 & $827(-4 \%)$ & $533(-38 \%)$ & $841(-3 \%)$ & $547(-37 \%)$ \\
\hline \multirow[t]{4}{*}{ 曰 } & Employment (Mil & & & & & & \\
\hline & Primair (plant) & 919 & 657 & $661(1 \%)$ & $630(-4 \%)$ & $658(0 \%)$ & $620(-6 \%)$ \\
\hline & Primair (dier) & 333 & 259 & $250(-4 \%)$ & $197(-24 \%)$ & $250(-4 \%)$ & $196(-24 \%)$ \\
\hline & Verwerkt & 778 & 495 & $490(-1 \%)$ & $456(-8 \%)$ & $492(-1 \%)$ & $457(-8 \%)$ \\
\hline 田 & GDP (Triljoen \$) & 78.1 & 201 & $201(0 \%)$ & $198(-2 \%)$ & $202(0 \%)$ & $200(-1 \%)$ \\
\hline
\end{tabular}




\begin{tabular}{|c|c|c|c|c|c|c|c|}
\hline \multicolumn{2}{|c|}{ Variable (unit) } & 2014 & 2050: Referentie & 2050: Groen EU, Gesloten & 2050: Groen Wrid, Gesloten & 2050: Groen EU, Open & 2050: Groen Wrid. Open \\
\hline \multicolumn{2}{|c|}{$\boxminus$ Emissions (Mt CO2-eq) } & 6221 & 8466 & $8264(-2 \%)$ & $5162(-39 \%)$ & $8354(-1 \%)$ & $5113(-40 \%)$ \\
\hline \multicolumn{2}{|c|}{ 日 Primair (plant) } & 2246 & $2370(0 \%)$ & $2342(-1 \%)$ & $1432(-40 \%)$ & $2343(-1 \%)$ & $1428(-40 \%)$ \\
\hline \multicolumn{2}{|c|}{ Carbon Dioxide } & 233 & 168 & $164(-3 \%)$ & $157(-7 \%)$ & $164(-2 \%)$ & $159(-5 \%)$ \\
\hline \multicolumn{2}{|r|}{ Methane } & 828 & 1048 & $1040(-1 \%)$ & $504(-52 \%)$ & $1038(-1 \%)$ & $501(-52 \%)$ \\
\hline \multicolumn{2}{|r|}{ Nitrious Oxide } & 1185 & 1155 & $1139(-1 \%)$ & $772(-33 \%)$ & $1141(-1 \%)$ & $768(-33 \%)$ \\
\hline \multirow[t]{4}{*}{ 日 } & Primair (dier) & 3643 & 5773 & $5602(-3 \%)$ & $3418(-41 \%)$ & $5691(-1 \%)$ & $3376(-42 \%)$ \\
\hline & Carbon Dioxide & 76.1 & 56.8 & $53.9(-5 \%)$ & $39.2(-31 \%)$ & $54.0(-5 \%)$ & $39.6(-30 \%)$ \\
\hline & Methane & 2360 & 3731 & $3608(-3 \%)$ & $2123(-43 \%)$ & $3668(-2 \%)$ & $2089(-44 \%)$ \\
\hline & Nitrious Oxide & 1207 & 1986 & $1940(-2 \%)$ & $1256(-37 \%)$ & $1969(-1 \%)$ & $1247(-37 \%)$ \\
\hline \multirow[t]{4}{*}{ 日 } & Verwerkt & 333 & 322 & $320(-1 \%)$ & $312(-3 \%)$ & $321(0 \%)$ & $309(-4 \%)$ \\
\hline & Carbon Dioxide & 329 & 317 & $315(-1 \%)$ & $307(-3 \%)$ & $316(0 \%)$ & $305(-4 \%)$ \\
\hline & Methane & 2.82 & 3.24 & $3.18(-2 \%)$ & $3.16(-3 \%)$ & $3.19(-2 \%)$ & $3.11(-4 \%)$ \\
\hline & Nitrious Oxide & 1.17 & 1.22 & $1.19(-2 \%)$ & $1.15(-5 \%)$ & $1.20(-1 \%)$ & $1.16(-5 \%)$ \\
\hline
\end{tabular}




\section{Bijlage 3 Extra decompositiegrafieken}

\section{B3.1 Productie}

\section{Bijdrage (\% 2014-2050) op verandering productie EU West}

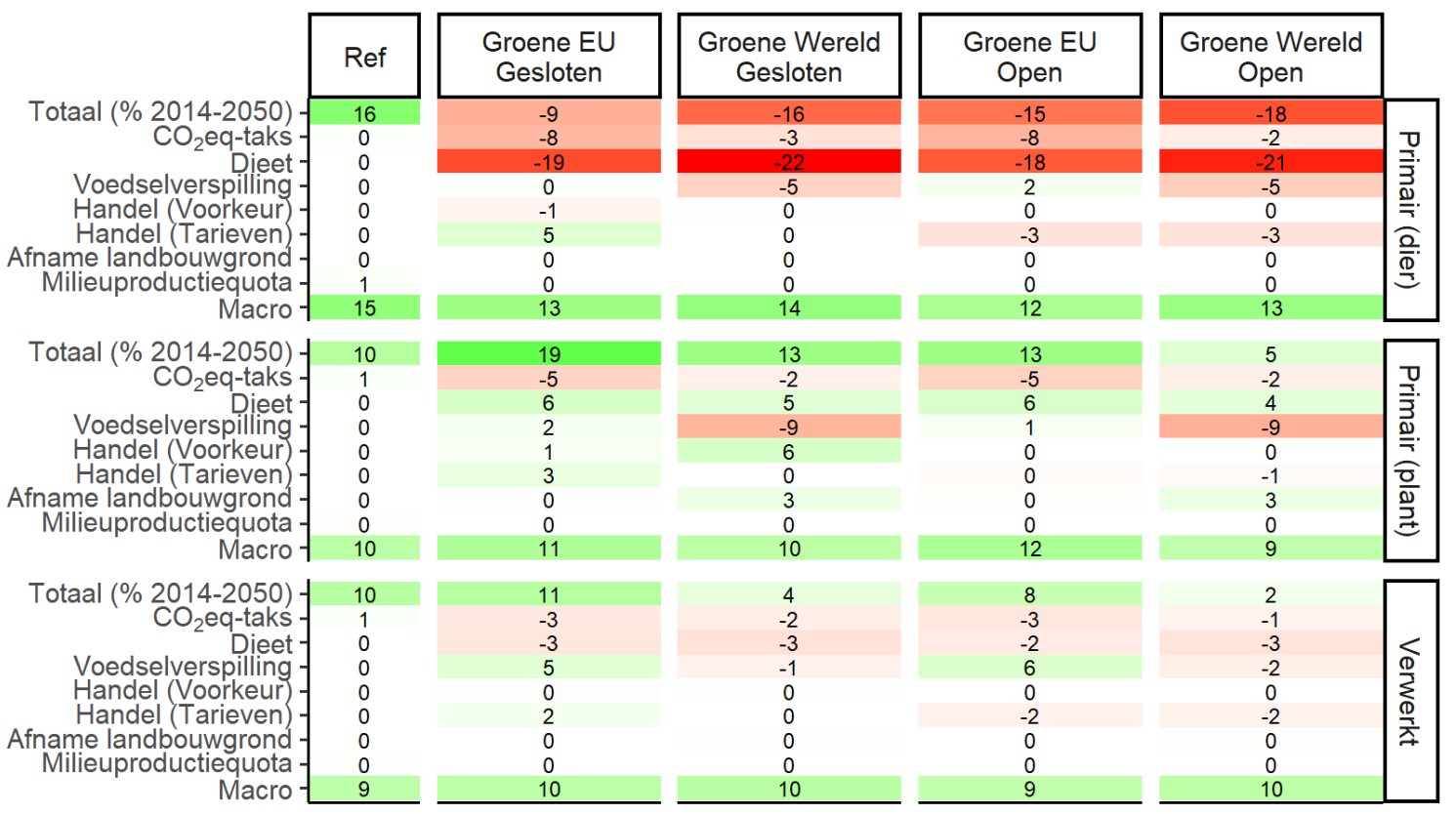

Figuur B3.1 Decompositie van productieverandering (2014-2050), EU West (exclusief Nederland)

\section{Bijdrage (\% 2014-2050) op verandering productie EU East}

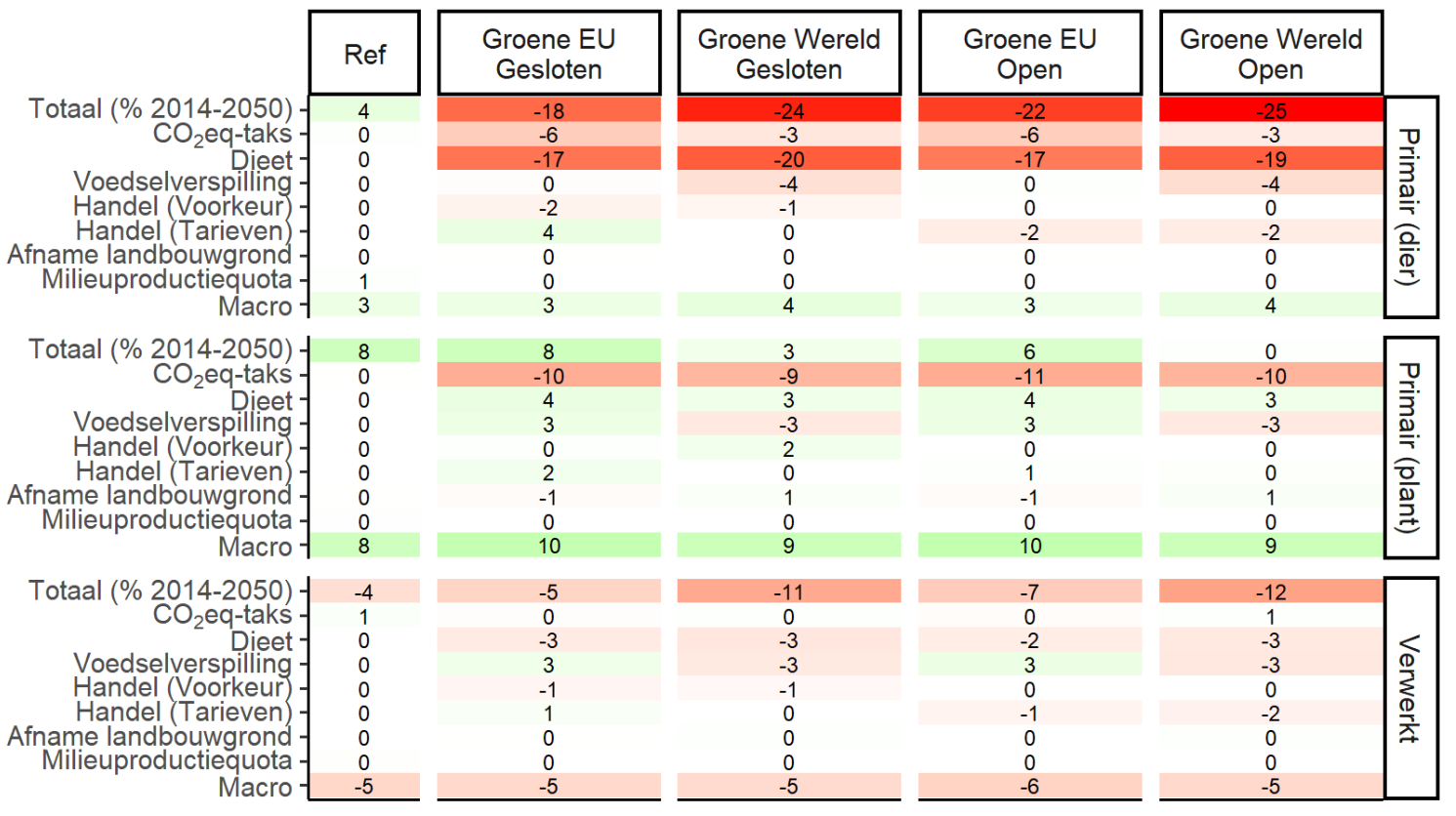

Figuur B3.2 Decompositie van productieverandering (2014-2050), EU Oost 
Bijdrage (\% 2014-2050) op verandering productie WorldExEU

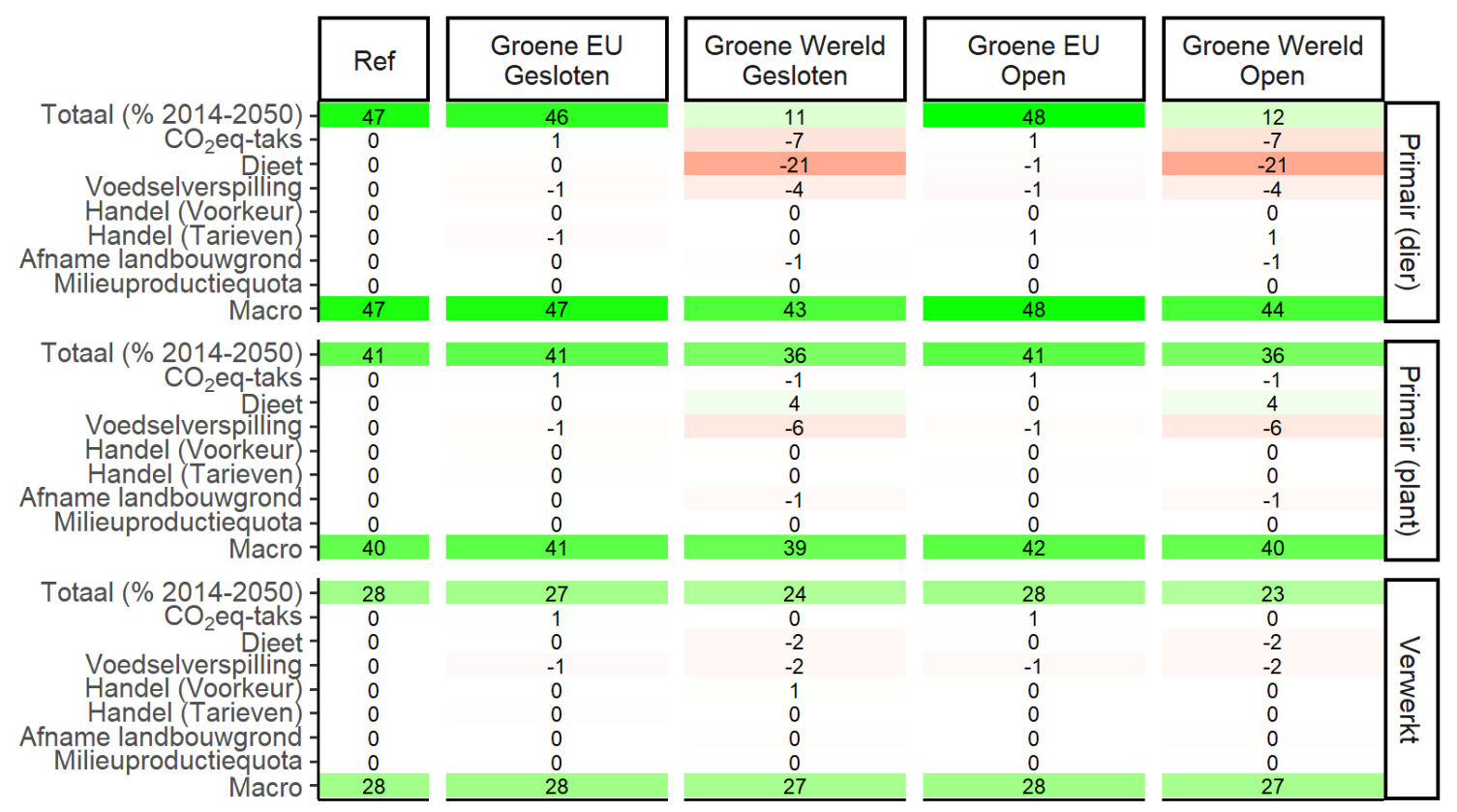

Figuur B3.3 Decompositie van productieverandering (2014-2050), Wereld (exclusief EU)

\section{B3.2 Emissies}

Bijdrage (\% 2014-2050) op verandering emissies in EU West

\begin{tabular}{|c|c|c|c|c|c|c|}
\hline \multirow[b]{2}{*}{$\begin{array}{r}\text { Totaal (\% 2014-2050) } \\
\mathrm{CO}_{2} \text { eq-taks - }\end{array}$} & Ref & $\begin{array}{l}\text { Groene EU } \\
\text { Gesloten }\end{array}$ & $\begin{array}{l}\text { Groene Wereld } \\
\text { Gesloten }\end{array}$ & $\begin{array}{l}\text { Groene EU } \\
\text { Open }\end{array}$ & $\begin{array}{c}\text { Groene Wereld } \\
\text { Open }\end{array}$ & \\
\hline & $\begin{array}{c}12 \\
0\end{array}$ & $\begin{array}{l}-39 \\
-27\end{array}$ & $\begin{array}{l}-43 \\
-18\end{array}$ & $\begin{array}{l}-46 \\
-25\end{array}$ & $\begin{array}{l}-43 \\
-15\end{array}$ & 0 \\
\hline$\left[\begin{array}{lll}-2 & -C \\
-1\end{array}\right.$ & 0 & -16 & -19 & -15 & -18 & : \\
\hline Voedselverspilling - & 0 & 0 & -5 & 1 & -5 & בై \\
\hline Handel (Voorkeur) & 0 & -1 & 0 & 0 & 0 & $\stackrel{\Perp}{=}$ \\
\hline Handel (Tarieven) & 0 & 7 & 0 & -5 & -4 & o \\
\hline Afname landbouwgrond - & 0 & 0 & 0 & 0 & 0 & $\frac{2}{\overline{0}}$ \\
\hline Milieuproductiequota - & 1 & 0 & 0 & 0 & 0 & \\
\hline Macro & 11 & 9 & 10 & 8 & 10 & \\
\hline Totaal (\% 2014-2050) - & -19 & -32 & -37 & -36 & -41 & \\
\hline $\mathrm{CO}_{2}$ eq-taks - & -2 & -17 & -11 & -18 & -12 & $\underset{D}{0}$ \\
\hline Dieet - & 0 & 3 & 2 & 3 & 2 & $\overline{3}$ \\
\hline Voedselverspilling - & 0 & -2 & -12 & -2 & -12 & $\underline{\underline{\omega}}$ \\
\hline Handel (Voorkeur) & 0 & 1 & 4 & 0 & 0 & $\bar{E}$ \\
\hline Handel (Tarieven) & 0 & 5 & 0 & 1 & 1 & $\widehat{0}$ \\
\hline Afname landbouwgrond & 0 & 0 & 2 & 0 & 3 & $\frac{0}{20}$ \\
\hline Milieuproductiequota & 0 & 0 & 0 & 0 & 0 & 롤 \\
\hline Macro- & -17 & -16 & -17 & -15 & -17 & \\
\hline Totaal (\% 2014-2050) - & -5 & -4 & -9 & -3 & -8 & \\
\hline $\mathrm{CO}_{2}$ eq-taks & -1 & -3 & -3 & -3 & -3 & \\
\hline Dieet - & 0 & 3 & 3 & 3 & 3 & $<$ \\
\hline Voedselverspilling & 0 & 0 & -5 & 0 & -5 & Ф) \\
\hline Handel (Voorkeur) & 0 & 0 & 0 & 0 & 0 & $\sum$ \\
\hline Handel (Tarieven) & 0 & 1 & 0 & 1 & 1 & $\stackrel{\mathbb{D}}{=}$ \\
\hline Afname landbouwgrond & 0 & 0 & 0 & 0 & 0 & $\lambda_{\overline{3}}$ \\
\hline Milieuproductiequota & 0 & 0 & 0 & 0 & 0 & \\
\hline M & -5 & -5 & -4 & -5 & -4 & \\
\hline
\end{tabular}

Figuur B3.4 Decompositie van emissieverandering (2014-2050), EU West (exclusief Nederland) 
Bijdrage (\% 2014-2050) op verandering emissies in EU East
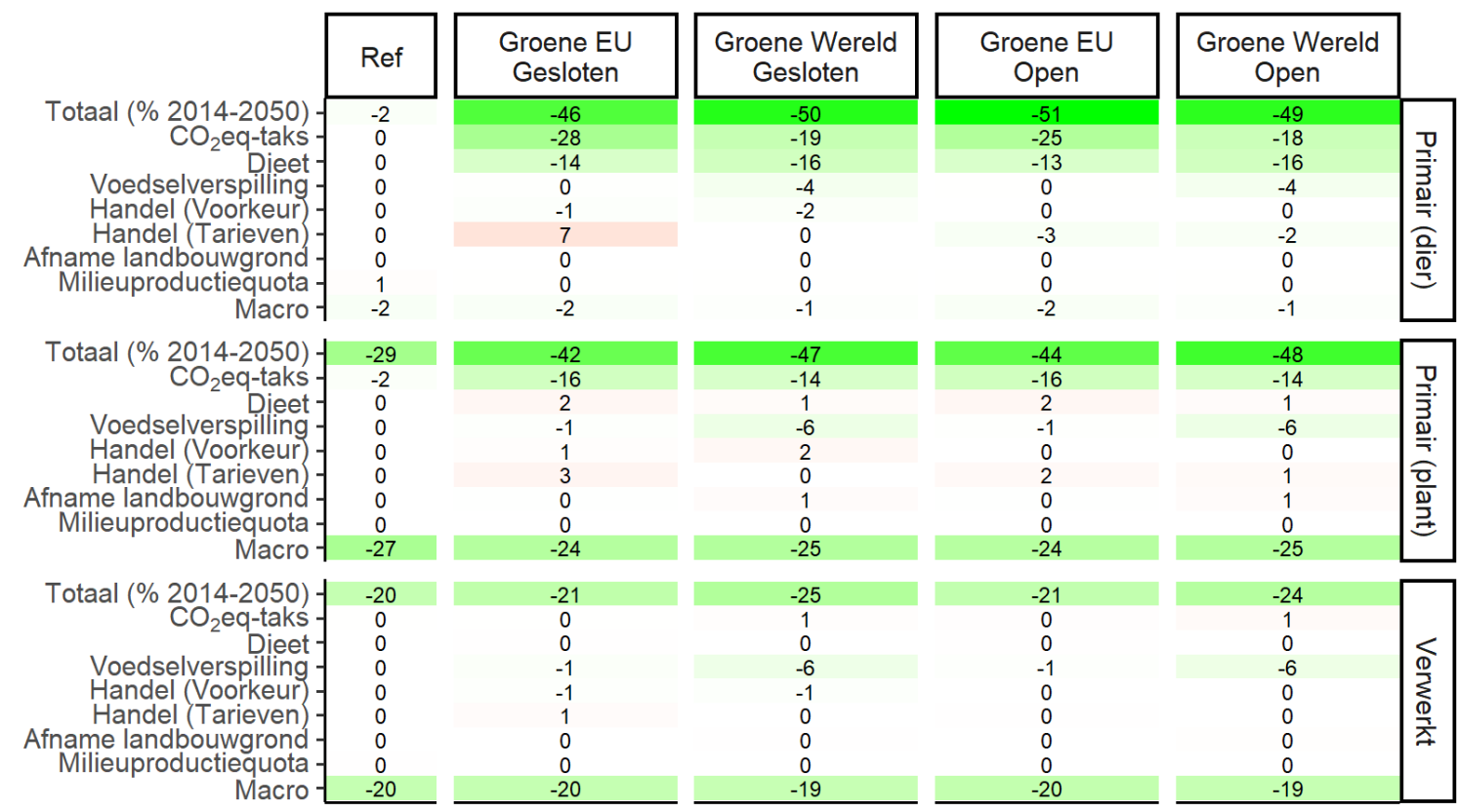

Figuur B3.5 Decompositie van emissieverandering (2014-2050), EU oost

\section{Bijdrage (\% 2014-2050) op verandering emissies in WorldExE}

\begin{tabular}{|c|c|c|c|c|c|c|}
\hline & Ref & $\begin{array}{l}\text { Groene EU } \\
\text { Gesloten }\end{array}$ & $\begin{array}{c}\text { Groene Wereld } \\
\text { Gesloten }\end{array}$ & $\begin{array}{c}\text { Groene EU } \\
\text { Open }\end{array}$ & $\begin{array}{c}\text { Groene Wereld } \\
\text { Open }\end{array}$ & \\
\hline Totaal (\% 2014-2050) & 63 & $\frac{62}{1}$ & $\begin{array}{c}-3 \\
-23\end{array}$ & $\begin{array}{c}65 \\
1\end{array}$ & $\begin{array}{l}-4 \\
-24\end{array}$ & \\
\hline Dieet & 0 & 0 & $\begin{array}{l}-23 \\
-14\end{array}$ & $\begin{array}{c}T \\
-1\end{array}$ & $\begin{array}{l}-24 \\
-14\end{array}$ & $\frac{0}{3}$ \\
\hline Voedselverspilling - & 0 & -1 & -6 & -1 & -6 & בู \\
\hline Handel (Voorkeur) - & 0 & 0 & 0 & 0 & 0 & 言: \\
\hline Handel (Tarieven) - & 0 & -1 & 0 & 2 & 1 & 을 \\
\hline Afname landbouwgrond - & 0 & 0 & -1 & 0 & -1 & 市 \\
\hline Milieuproductiequota & 0 & 0 & 0 & 0 & 0 & 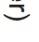 \\
\hline Macro & 63 & 62 & 53 & & 53 & \\
\hline Totaal (\% 2014-2050) - & 8 & 7 & -36 & 8 & -36 & \\
\hline $\mathrm{CO}_{2} \mathrm{eq}$-taks & 0 & 0 & -17 & 1 & -17 & $\underset{D}{0}$ \\
\hline Dieet - & 0 & 0 & 1 & 0 & 1 & $\overline{3}$ \\
\hline Voedselverspilling - & 0 & -1 & -7 & -1 & -7 & $\stackrel{\underline{\omega}}{=}$ \\
\hline Handel (Voorkeur) - & 0 & 0 & 0 & 0 & 0 & 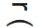 \\
\hline Handel (Tarieven) - & 0 & 0 & 0 & 0 & 0 & 으 \\
\hline Afname landbouwgrond - & 0 & 0 & 0 & 0 & 0 & 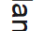 \\
\hline Milieuproductiequota - & 0 & 0 & 0 & 0 & 0 & ᄅ \\
\hline Macro & 8 & 8 & 7 & 8 & 7 & \\
\hline Totaal (\% 2014-2050) - & -3 & -4 & -6 & -3 & -6 & \\
\hline $\mathrm{CO}_{2}$ eq-taks & 0 & 0 & 1 & 0 & 1 & \\
\hline Dieet - & 0 & 0 & 1 & 0 & 1 & $<$ \\
\hline Voedselverspilling - & 0 & -1 & -6 & -1 & -6 & $\Phi$ \\
\hline Handel (Voorkeur) & 0 & 0 & 1 & 0 & 0 & $\sum$ \\
\hline Handel (Tarieven) & 0 & 0 & 0 & 0 & 0 & $\underline{\underline{D}}$ \\
\hline Afname landbouwgrond & 0 & 0 & 0 & 0 & 0 & ¿ \\
\hline Milieuproductiequota & 0 & 0 & 0 & 0 & 0 & \\
\hline Macr & -3 & -3 & -3 & -3 & -3 & \\
\hline
\end{tabular}

Figuur B3.6 Decompositie van emissieverandering (2014-2050), Wereld exclusief EU 


\section{B3.3 Prijzen}

Bijdrage (\% 2014-2050) op productieprijs in EU

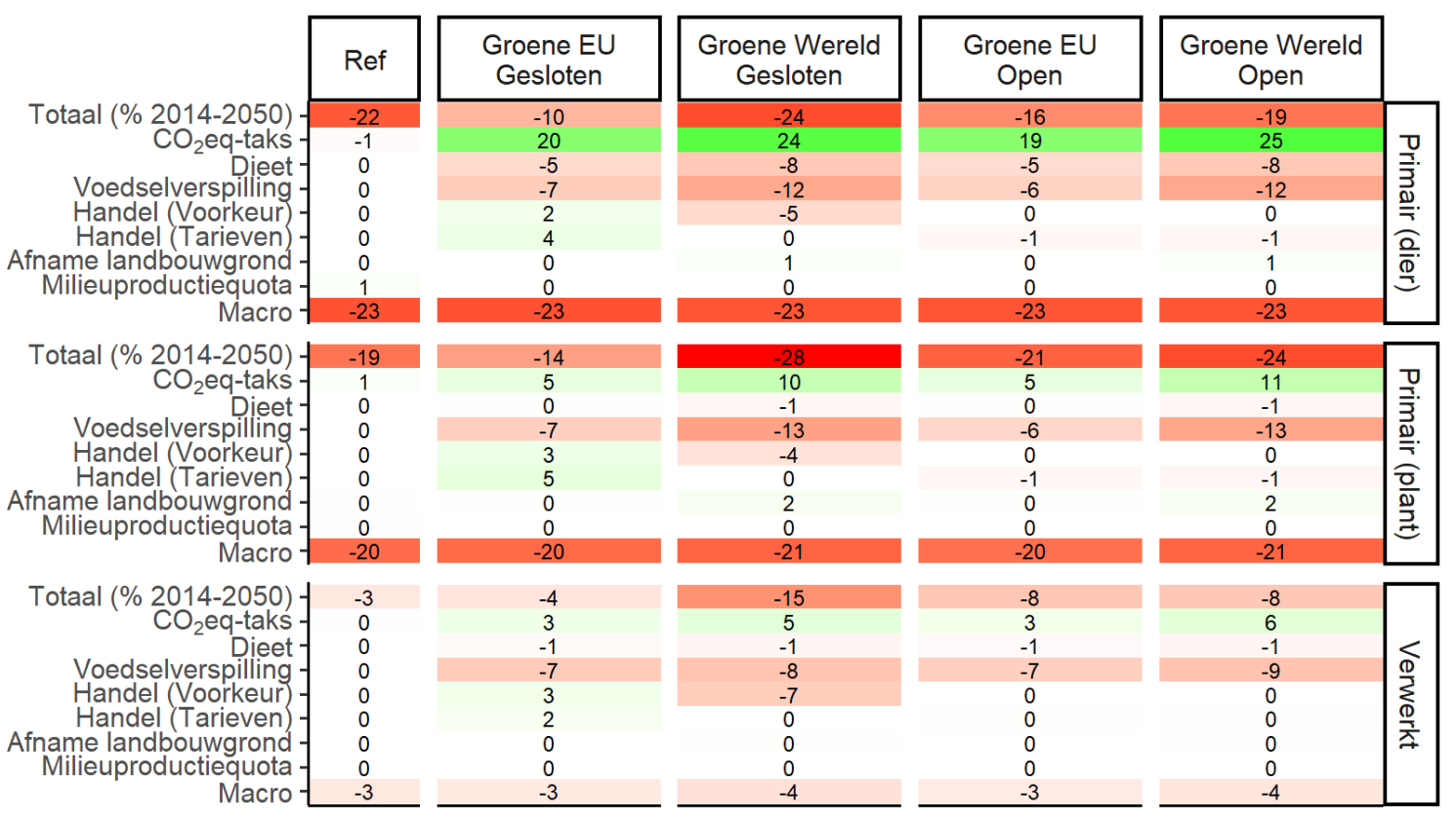

Figuur B3.7 Decompositie van prijsverandering (2014-2050), EU totaal

\section{Bijdrage (\% 2014-2050) op productieprijs in World}

\begin{tabular}{|c|c|c|c|c|c|c|}
\hline & Ref & $\begin{array}{l}\text { Groene EU } \\
\text { Gesloten }\end{array}$ & $\begin{array}{c}\text { Groene Wereld } \\
\text { Gesloten }\end{array}$ & $\begin{array}{l}\text { Groene EU } \\
\text { Open }\end{array}$ & $\begin{array}{c}\text { Groene Wereld } \\
\text { Open }\end{array}$ & \\
\hline $\begin{array}{r}\text { Totaal (\% 2014-2050) } \\
\mathrm{CO}_{2} \text { eq-taks } \\
\text { Dieet } \\
\text { Voedselverspilling } \\
\text { Handel (Voorkeur) } \\
\text { Handel (Tarieven) } \\
\text { Afname landbouwgrond - } \\
\text { Milieuproductiequota - } \\
\text { Macro - }\end{array}$ & $\begin{array}{c}-19 \\
0 \\
0 \\
0 \\
0 \\
0 \\
0 \\
0 \\
-19\end{array}$ & $\begin{array}{c}-19 \\
3 \\
-1 \\
-2 \\
0 \\
0 \\
0 \\
0 \\
-19\end{array}$ & $\begin{array}{c}9 \\
46 \\
-5 \\
-14 \\
-1 \\
0 \\
2 \\
0 \\
-19\end{array}$ & $\begin{array}{c}-19 \\
3 \\
-1 \\
-2 \\
0 \\
0 \\
0 \\
0 \\
-19\end{array}$ & $\begin{array}{c}9 \\
46 \\
-5 \\
-13 \\
0 \\
0 \\
2 \\
0 \\
-19\end{array}$ & 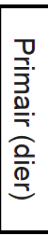 \\
\hline $\begin{array}{r}\text { Totaal (\% 2014-2050)- } \\
\mathrm{CO}_{2} \text { eq-taks } \\
\text { Dieet } \\
\text { Voedselverspilling } \\
\text { Handel (Voorkeur) } \\
\text { Handel (Tarieven) } \\
\text { Afname landbouwgrond } \\
\text { Milieuproductiequota } \\
\text { Macro }\end{array}$ & $\begin{array}{c}-14 \\
1 \\
0 \\
0 \\
0 \\
0 \\
0 \\
0 \\
-14\end{array}$ & $\begin{array}{c}-14 \\
1 \\
0 \\
-2 \\
0 \\
0 \\
0 \\
0 \\
-14\end{array}$ & $\begin{array}{c}-20 \\
11 \\
-3 \\
-17 \\
-1 \\
0 \\
5 \\
0 \\
-15\end{array}$ & $\begin{array}{c}-14 \\
1 \\
0 \\
-2 \\
0 \\
-1 \\
0 \\
0 \\
-13\end{array}$ & $\begin{array}{c}-19 \\
11 \\
-3 \\
-16 \\
0 \\
-1 \\
5 \\
0 \\
-15\end{array}$ & 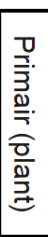 \\
\hline $\begin{array}{r}\text { Totaal (\% 2014-2050)- } \\
\mathrm{CO}_{2} \text { eq-taks } \\
\text { Dieet } \\
\text { Voedselverspilling } \\
\text { Handel (Voorkeur) } \\
\text { Handel (Tarieven)- } \\
\text { Afname landbouwgrond } \\
\text { Milieuproductiequota- } \\
\text { Macro }\end{array}$ & $\begin{array}{l}-2 \\
0 \\
0 \\
0 \\
0 \\
0 \\
0 \\
0 \\
-2\end{array}$ & $\begin{array}{c}-2 \\
1 \\
0 \\
-2 \\
0 \\
0 \\
0 \\
0 \\
-2\end{array}$ & $\begin{array}{c}-7 \\
7 \\
-1 \\
-10 \\
-1 \\
0 \\
1 \\
0 \\
-2\end{array}$ & $\begin{array}{c}-3 \\
1 \\
0 \\
-2 \\
0 \\
0 \\
0 \\
0 \\
-2\end{array}$ & $\begin{array}{c}-6 \\
7 \\
-1 \\
-10 \\
0 \\
0 \\
1 \\
0 \\
-2\end{array}$ & 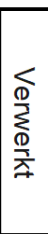 \\
\hline
\end{tabular}

Figuur B3.8 Decompositie van prijsverandering (2014-2050), Wereld totaal 


\section{Bijdrage (\% 2014-2050) op productieprijs in EU West}

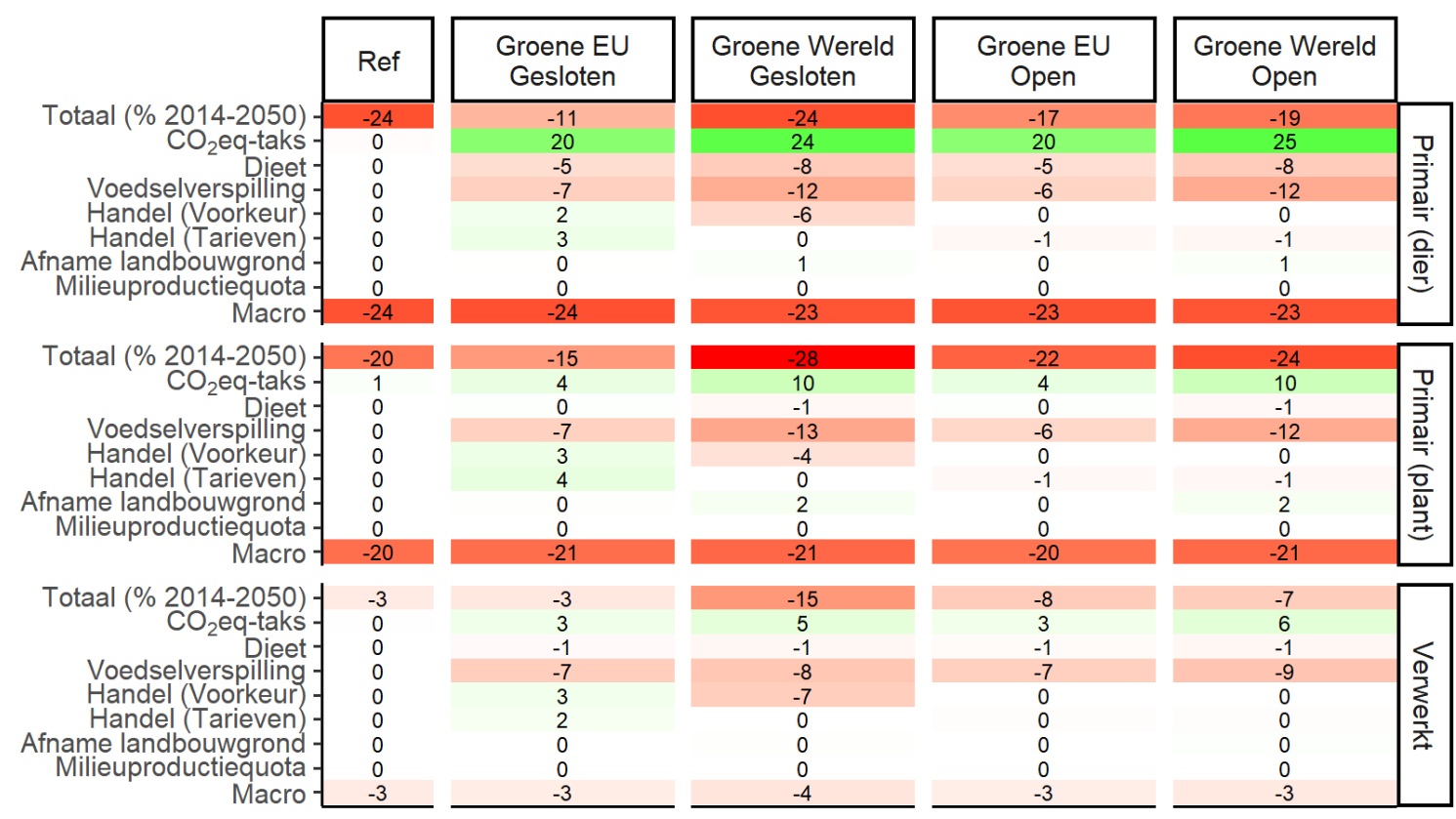

Figuur B3.9 Decompositie van prijsverandering (2014-2050), EU West (exclusief Nederland)

\section{Bijdrage (\% 2014-2050) op productieprijs in EU East}

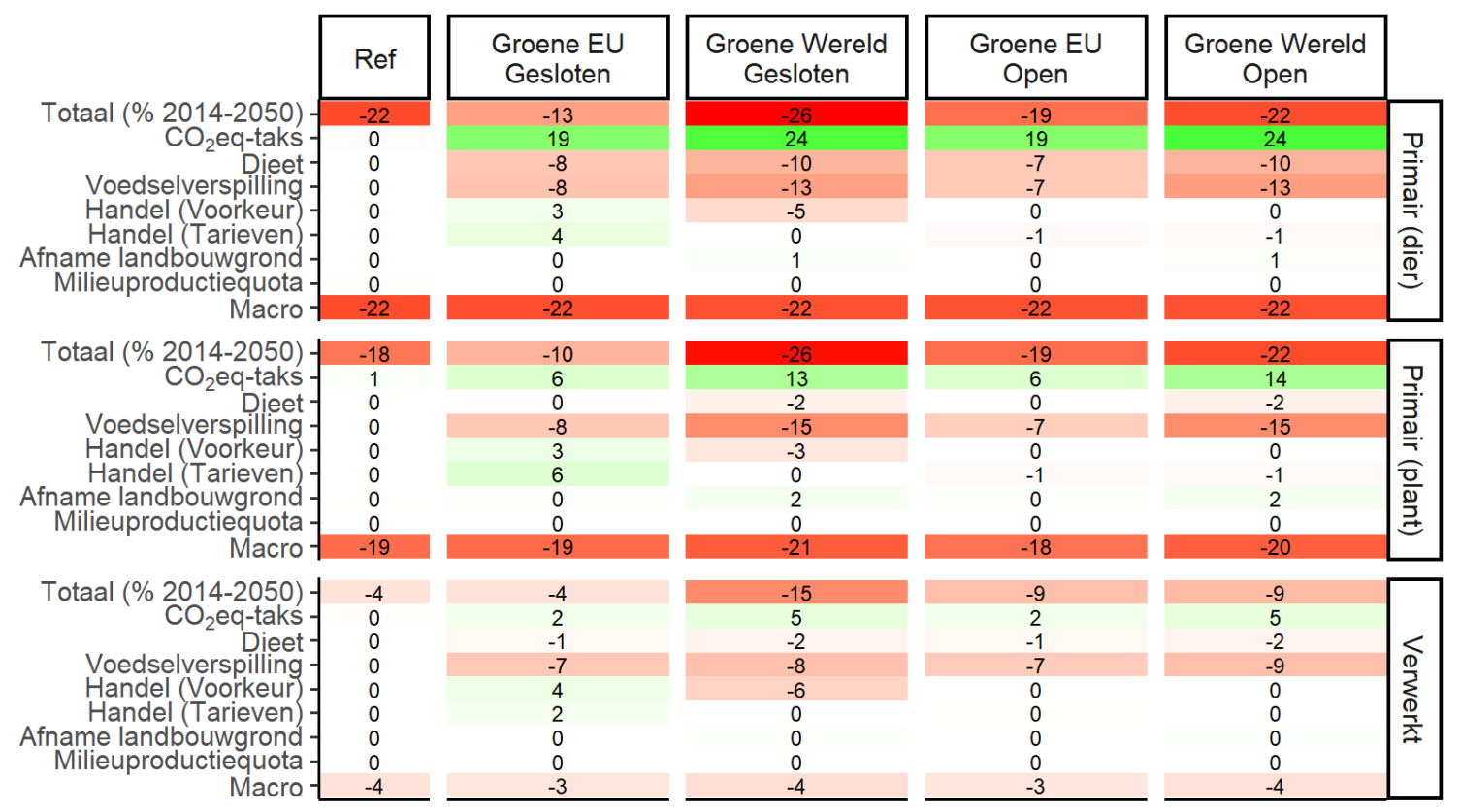

Figuur B3.10 Decompositie van prijsverandering (2014-2050), EU Oost 


\section{Bijdrage (\% 2014-2050) op productieprijs in WorldExEU}
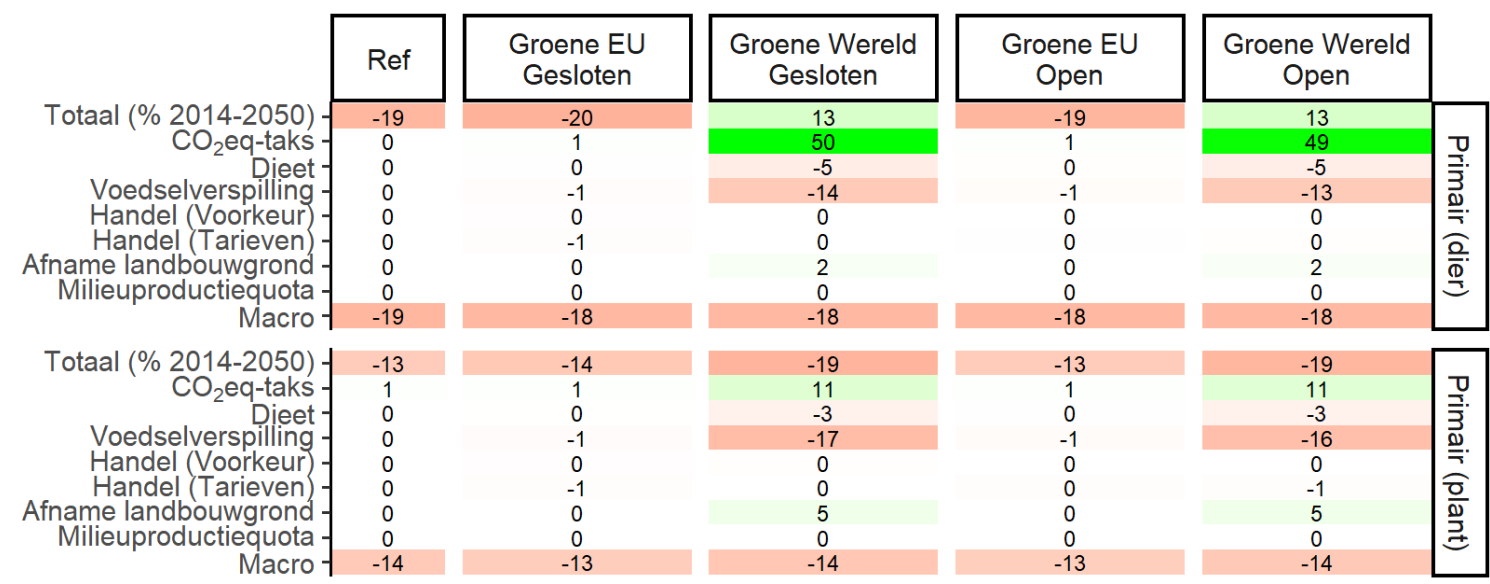

Totaal (\% 2014-2050)- -1
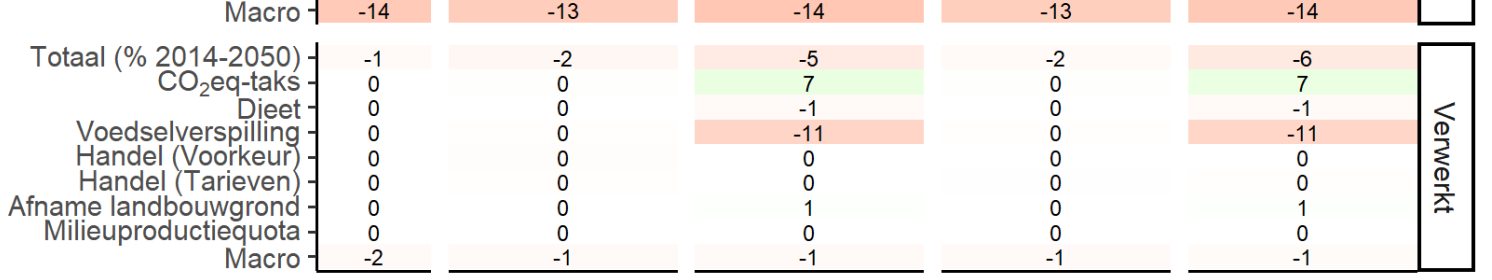

Figuur B3.11 Decompositie van prijsverandering (2014-2050), Wereld exclusief EU.

\section{B3.4 Handel}

\section{Bijdrage (\% 2014-2050) op export EU naar WorldExEU}

\begin{tabular}{|c|c|c|c|c|c|c|}
\hline \multirow[b]{2}{*}{$\begin{array}{r}\text { Totaal (\% 2014-2050) } \\
\mathrm{CO}_{2} \text { eq-taks }\end{array}$} & Ref & $\begin{array}{l}\text { Groene EU } \\
\text { Gesloten }\end{array}$ & $\begin{array}{l}\text { Groene Wereld } \\
\text { Gesloten }\end{array}$ & $\begin{array}{l}\text { Groene EU } \\
\text { Open }\end{array}$ & $\begin{array}{c}\text { Groene Wereld } \\
\text { Open }\end{array}$ & \\
\hline & $\begin{array}{c}34 \\
1\end{array}$ & $\begin{array}{c}54 \\
-43\end{array}$ & $\begin{array}{l}-7 \\
4\end{array}$ & $\begin{array}{c}33 \\
-33\end{array}$ & $\begin{array}{c}43 \\
5\end{array}$ & 0 \\
\hline $\begin{array}{l}\text { Dieet } \\
\text { Dien }\end{array}$ & 0 & 12 & -8 & 10 & -10 & : \\
\hline Voedselverspilling & 0 & 15 & -2 & 12 & -2 & בై \\
\hline Handel (Voorkeur) & 0 & -12 & -34 & 0 & 0 & $\stackrel{\Perp}{=}$ \\
\hline Handel (Tarieven) & 0 & 49 & 0 & 8 & 9 & o \\
\hline Afname landbouwgrond & 0 & 0 & 0 & 0 & 0 & 咅 \\
\hline Milieuproductiequota & 0 & 0 & 0 & 0 & 0 & \\
\hline Macro & 33 & 31 & 33 & 34 & 40 & \\
\hline Totaal (\% 2014-2050) & 16 & 18 & -6 & 30 & 15 & \\
\hline $\mathrm{CO}_{2} \mathrm{eq}$-taks & -1 & -17 & 0 & -17 & -1 & $\underset{D}{0}$ \\
\hline Dieet & 0 & 0 & -1 & -1 & -1 & $\frac{2}{3}$ \\
\hline Voedselverspilling & 0 & 17 & -14 & 15 & -16 & $\underline{\underline{D}}$ \\
\hline Handel (Voorkeur) & 0 & -14 & -13 & 0 & 0 & $\bar{E}$ \\
\hline Handel (Tarieven) & 0 & 12 & 0 & 11 & 11 & $\widehat{0}$ \\
\hline Afname landbouwgrond & 0 & 0 & 7 & 0 & 8 & $\frac{0}{20}$ \\
\hline Milieuproductiequota & 0 & 0 & 0 & 0 & 0 & 㞎 \\
\hline Macro & 18 & 20 & 14 & 21 & 14 & \\
\hline Totaal (\% 2014-2050). & 30 & 48 & -5 & 73 & 41 & \\
\hline $\mathrm{CO}_{2}$ eq-taks & 1 & -13 & -5 & -13 & -5 & \\
\hline Dieet & 0 & 4 & 2 & 4 & 2 & $<$ \\
\hline Voedselverspilling & 0 & 32 & -5 & 34 & -6 & ब \\
\hline Handel (Voorkeur) & 0 & -15 & -30 & 0 & 0 & $\sum$ \\
\hline Handel (Tarieven) & 0 & 10 & 0 & 19 & 17 & $\Phi$ \\
\hline Afname landbouwgrond & 0 & 0 & 2 & 0 & 2 & 궇 \\
\hline Milieuproductiequota & 0 & 0 & 0 & 0 & 0 & \\
\hline$M$ & 29 & 30 & 31 & 29 & 32 & \\
\hline
\end{tabular}

Figuur B3.12 Decompositie van exportverandering (2014-2050), EU naar Wereld buiten EU 


\section{Bijdrage (\% 2014-2050) op import EU van WorldExEU}

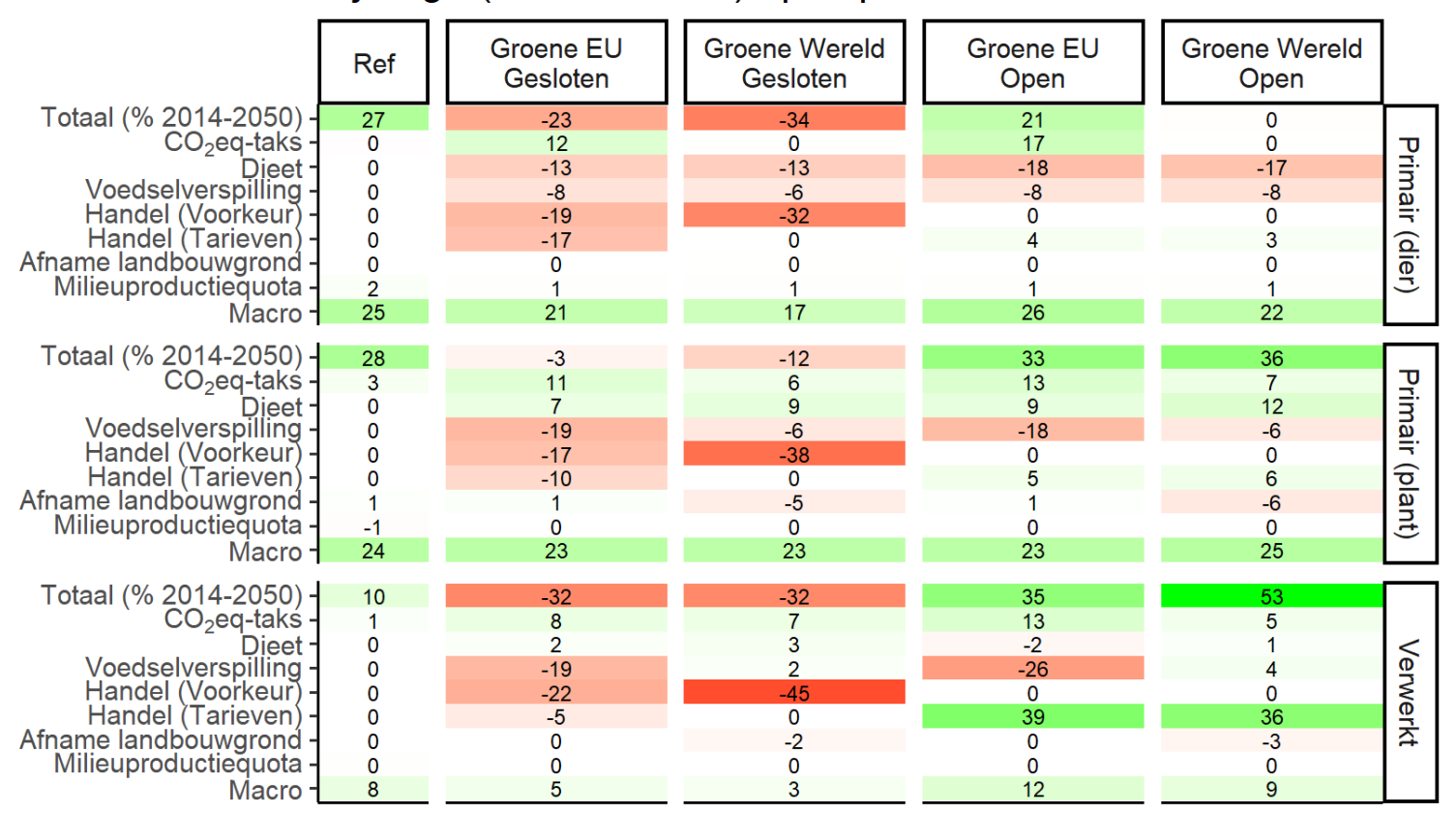

Figuur B3.13 Decompositie van importverandering (2014-2050), EU van Wereld buiten EU 
Wageningen Economic Research Postbus 29703

2502 LS Den Haag

T 0703358330

Ecommunications.ssg@wur.nl

www.wur.nl/economic-research

Wageningen Economic Research RAPPORT

2021-135
De missie van Wageningen University \& Research is 'To explore the potential of nature to improve the quality of life'. Binnen Wageningen University \& Research bundelen Wageningen University en gespecialiseerde onderzoeksinstituten van Stichting Wageningen Research hun krachten om bij te dragen aan de oplossing van belangrijke vragen in het domein van gezonde voeding en leefomgeving. Met ongeveer 30 vestigingen, 6.800 medewerkers (6.000 fte) en 12.900 studenten behoort Wageningen University \& Research wereldwijd tot de aansprekende kennisinstellingen binnen haar domein. De integrale benadering van de vraagstukken en de samenwerking tussen verschillende disciplines vormen het hart van de unieke Wageningen aanpak. 



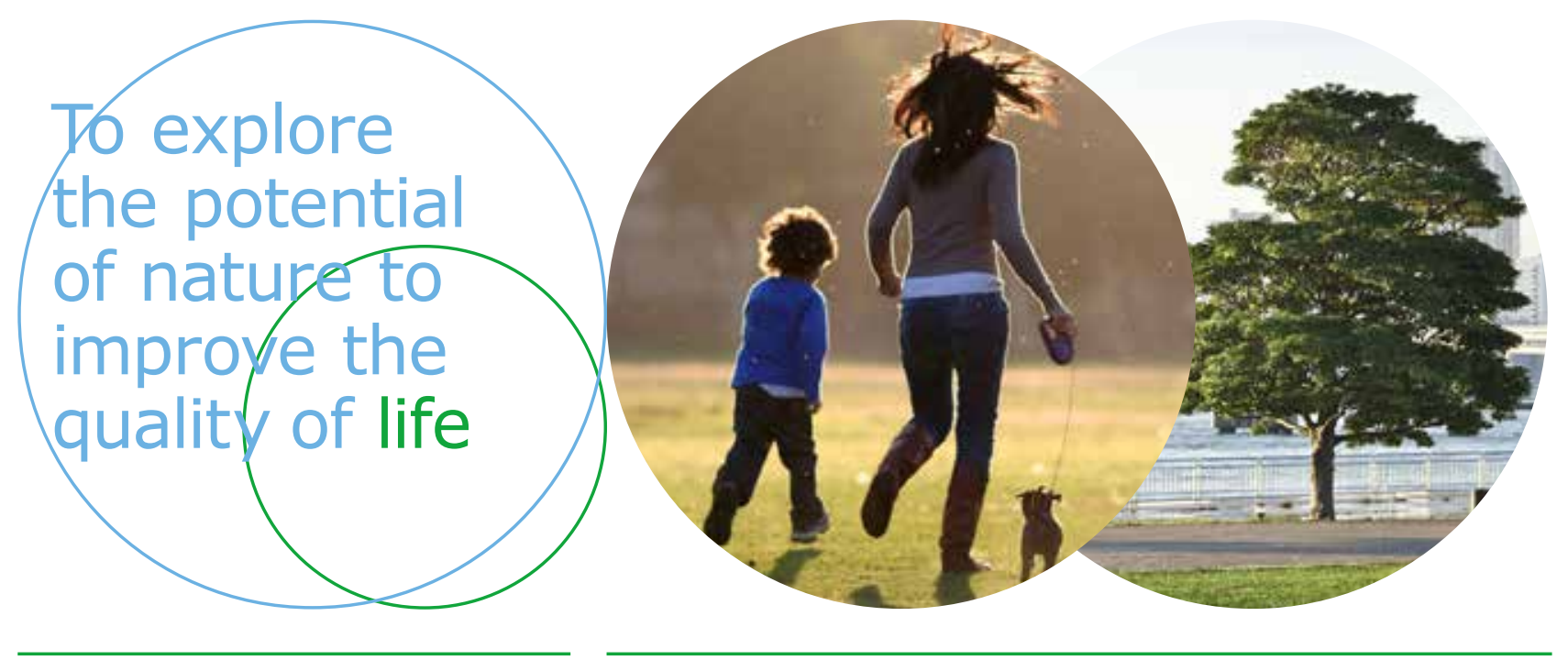

Wageningen Economic Research Postbus 29703

2502 LS Den Haag

T 0703358330

E communications.ssg@wur.nl www.wur.nl/economic-research

Rapport 2021-135

ISBN 978-94-6447-038-3
De missie van Wageningen University \& Research is 'To explore the potential of nature to improve the quality of life'. Binnen Wageningen University \& Research bundelen Wageningen University en gespecialiseerde onderzoeksinstituten van Stichting Wageningen Research hun krachten om bij te dragen aan de oplossing van belangrijke vragen in het domein van gezonde voeding en leefomgeving. Met ongeveer 30 vestigingen, 6.800 medewerkers ( $6.000 \mathrm{fte}$ ) en 12.900 studenten behoort Wageningen University \& Research wereldwijd tot de aansprekende kennisinstellingen binnen haar domein. De integrale benadering van de vraagstukken en de samenwerking tussen verschillende disciplines vormen het hart van de unieke Wageningen aanpak. 